\title{
Avaliação da qualidade sanitária e ocorrência de Aeromonas spp em lagoas de pesque-pague da Região Metropolitana de São Paulo
}

\author{
Marisa Morita
}

Dissertação apresentada ao Programa de Pós-Graduação em Saúde Pública para obtenção do título de Mestre em Saúde Pública.

Área de Concentração: Serviços de Saúde Pública.

Orientador: Prof. Dr. Glavur Rogério Matté

São Paulo

2005

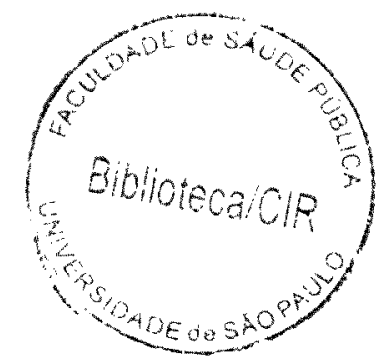




\section{Dedicatória}

Aos meus pais Naná e Mitsuo por todos os ensinamentos, incentivos, dedicação e principalmente pelo amor proporcionado em todos os momentos de minha vida.

Aos meus irmãos Márcia e Marcos por todo amor, estímulo, compreensão e união.

À Naiara pela amizade, confiança e apoio constante.

Ao Denis, meu companheiro e amigo, que sempre esteve ao meu lado em todos os momentos, participando, incentivando e principalmente compartilhando todo seu amor e compreensão. 


\section{Agradecimentos}

À Deus por toda força e saúde que me motiva a continuar sempre em busca de meus objetivos.

Ao Prof. Dr. Glavur Rogério Matté pela orientação, confiança e apoio durante todo o período do projeto.

À Profa. Dra. Maria Helena Matté pela oportunidade de estágio no Laboratório de Saúde Pública e pelos incentivos proporcionados para a realização do curso de aprimoramento FUNDAP e, posteriormente, o de mestrado. E também pela sincera amizade, paciência e pelos valiosos ensinamentos e dedicação prestados durante todo o periodo em que estive no laboratório.

À Dra. Lúcia Baldassi pela amizade e pelas sugestões durante o exame de qualificação e pré-banca.

À Dra. Katharina Eichbaum Esteves pela oportunidade de participar do projeto dos pesqueiros, pela disponibilidade de dados e pelos conselhos utilizados na conclusão do presente estudo.

À Dra. Cacilda Thais J. Mercante pelo auxílio nas coletas de amostras de água e pela disponibilidade de dados físico-químicos para as análises estatísticas.

À Pesquisadora Maria Angela Cabianca pelo auxílio na execução das coletas de amostras de água e disponibilidade de dados de zooplâncton para a realização dos testes estatísticos.

Ao Pesquisador Carlos Massatoshi Ishikawa, Esequiel Liuson e ao técnico Estevar pelo auxílio prestado nas coletas de amostras de peixe. 
Aos professores e funcionários da Faculdade de Saúde Pública pelo auxílio e incentivo proporcionado, em especial, a Profa. Dra. Nicolina Lieber e Prof. Dr. Délsio Natal.

Aos funcionários da Secretaria de Pós-Graduação e Serviço de Aprimoramento, em especial à Ângela, Márcia e Cidinha, pelo eficiente trabalho prestado.

Ao Laboratório de Bromatologia da Faculdade de Saúde Pública pelo fornecimento de material utilizado na execução do trabalho.

Aos funcionários da Biblioteca, especialmente à Gisele e Márcia pela competência e dedicação com que exercem seu trabalho.

Aos seguranças da Faculdade de Saúde Pública, Jairo e Paulo, pela simpatia e incentivo prestado durante toda etapa de execução do trabalho. Aos proprietários dos pesqueiros que permitiram a coleta de amostras e aquisição de informações a respeito de seus estabelecimentos.

À Agnes por ter proporcionado o contato inicial com o Laboratório de Saúde Pública, pela confiança depositada na realização do trabalho com "streetfood", pelos valiosos ensinamentos e principalmente pela sincera amizade. À Andréa pela amizade, companheirismo, auxilio e pelos bons momentos compartilhados durante todo o período do mestrado.

À Luciana que participou intensamente da etapa inicial de extração de DNA. À Maria do Carmo, Célia, Silvana e Therezinha pela amizade e pelos momentos especiais que proporcionaram muita alegria.

À Milena pela amizade, ajuda e incentivo durante toda etapa, desde a coleta à finalização do trabalho. 
À Miriam por todo apoio prestado (muitas vezes, on-line), pelo empréstimo e troca de artigos científicos, pelo auxilio na montagem dos esquemas, pelos ricos ensinamentos e pela grande amizade.

À Solange pela verdadeira amizade e apoio constante em todas as etapas do mestrado, pelo auxilio na busca de referências científicas, pelo companheirismo e pelos momentos felizes compartilhados durante todo este periodo.

A Suzete pela sincera amizade e todo apoio acadêmico e laboratorial proporcionado durante todo a andamento da pesquisa.

A Viraneide por toda ajuda prestada durante as etapas de coleta e processamento das amostras analisadas.

À todos os demais colegas do Laboratório de Saúde Pública, que num momento ou outro ajudaram a finalizar este estudo sempre com muito bom humor e alto astral: Ana Maria, Fernanda, Karla, Márcia, Martha, Rita, Rosinha, Suzi, Thiago, Vandrea e Vera.

À FAPESP (Fundação de Amparo a Pesquisa) pelo auxilio financeiro à pesquisa.

Ao CNPq (Conselho Nacional de Desenvolvimento Científico e Tecnológico) pela concessão de bolsa de mestrado.

Ao CECOVISA (Centro Colaborador e Vigilância Sanitária/FSP) pelo auxilio financeiro concedido ao projeto. 


\section{RESUMO}

Morita M. Avaliação da qualidade sanitária e ocorrência de Aeromonas spp em lagoas de pesque-pague da Região Metropolitana de São Paulo. São Paulo. 2004 [Dissertação de Mestrado - Faculdade de Saúde Pública da USP]

Introdução. As atividades de pesca esportiva, denominadas lagoas de pesque-pague, têm sido utilizadas como alternativa de lazer pela maioria das pessoas que vivem nos grandes centros urbanos. Entretanto, as condições sanitárias das águas desses estabelecimentos é uma importante questão na manutenção da saúde dos consumidores. Objetivo. Avaliar as condições sanitárias da água e a ocorrência do gênero Aeromonas em lagoas de pesque-pague localizados na Região Metropolitana de São Paulo. Métodos. Amostras de 30 lagoas de pesca foram obtidas durante as estações seca (inverno) e chuvosa (verão), para contagem de coliformes fecais e ocorrência de bactérias patogênicas tais como Salmonella spp e Aeromonas spp, de acordo com APHA (1995) e técnicas moleculares segundo AUSUBEL e col. (1995). Resultados. Cerca de 53,3\% das lagoas de pesca apresentaram coliformes fecais e Salmonella spp acima dos valores recomendados pelo Conselho Nacional do Meio Ambiente (CONAMA No 2001/06/86) durante a estação seca e cerca de $33,3 \%$ na chuvosa. O gênero Aeromonas foi observada em alta freqüência (>80\%) nas lagoas de pesca, durante os períodos seco e chuvoso. Em adição, uma alta diversidade de espécies de Aeromonas foi observada também nas amostras de água (61\%) e peixe $(55,5 \%)$ Conclusōes. Os elevados niveis de matéria orgânica nos reservatórios observados durante a estação chuvosa contribuiram para os niveis de coliformes fecais e Aeromonas spp, além disso, a prática de manejo inadequada contribuiu para a manutenção de uma qualidade da água insatisfatória. Em adição, cepas de Aeromonas spp detectadas nas amostras de água e peixe, durante ambos os periodos, apresentaram uma elevada porcentagem de plasmídios, sugerindo a ocorrência de fatores de resistência neste grupo de bactérias patogênicas.

Descritores: Coliformes fecais, E. coli, Salmonella spp, Aeromonas spp, Pesque-pague, Qualidade da Água, Plasmídio, Saúde Pública 


\section{SUMMARY}

Morita M. The evaluation of sanitary conditions and the ocurrence of the genus Aeromonas in fee-fishing ponds located in the São Paulo Metropolitan Region, Brazil. São Paulo. 2004 [Dissertação de Mestrado Faculdade de Saúde Pública da USP]

Introduction. The activities of sportive fishing called as Fee-fishing ponds have been used as recreational alternative for most of the people who live in populous urban centers. However, the sanitary condition of the water of these establishments is an important issue in maintaining the consumer's health. Objective. Evaluate the sanitary conditions of the water and the occurrence of genus Aeromonas in fee-fishing ponds located in São Paulo Metropolitan Region. Methods. Samples from 30 fishing ponds were taken during the dry (winter) and rainy (summer) seasons to measure fecal coliform and occurrence of pathogenic bacteria such as Salmonella spp and Aeromonas spp following APHA (1995) and molecular techniques according to AUSUBEL (1995). Results. About $53,3 \%$ of the fishing ponds presented fecal coliforms and Salmonella spp, above the recommended values of the National Council of Environment (CONAMA No.20 - 01/06/86), during dry season and about $33,3 \%$ in the rainy. The genus Aeromonas was observed with high frequency $(>80 \%)$ in fishing ponds, during dry and rainy seasons. In addition, a high diversity of species of Aeromonas was also observed in water $(61 \%)$ and fish samples $(55,5 \%)$. Conclusions. The high levels of organic nutrients in the reservoirs observed during the rainy season contributed to the levels of fecal coliforms and Aeromonas spp. besides, improper management practices contributed to the maintenance of unsuitable water quality. In addition, Aeromonas strains detected in water and fish samples during both seasons presented a high percentage of plasmids, suggesting the occurrence of resistance factors in this group of pathogenic bacteria.

Describers: Fecal Coliforms, Escherichia coli, Salmonella spp, Aeromonas spp, Fee-fishing ponds, Water Quality, Fish Quality, Management, Plasmid, Public Health. 


\section{ÍNDICE}

1. INTRODUÇÃO 1

2. ANÁLISE DE LITERATURA 5

2.1. Coliformes fecais e Escherichia coli 5

$\begin{array}{ll}\text { 2.1.1. Ocorrência } & 6\end{array}$

$\begin{array}{ll}\text { 2.1.2. Qualidade da Água } & 7\end{array}$

$\begin{array}{ll}\text { 2.1.3. Patogenia } & 8\end{array}$

$\begin{array}{ll}\text { 2.2. Salmonella spp } & 10\end{array}$

$\begin{array}{lr}\text { 2.2.1. Taxonomia } & 10\end{array}$

$\begin{array}{ll}\text { 2.2.2. Ocorrência } & 11\end{array}$

$\begin{array}{lr}\text { 2.2.3. Patogenia } & 12\end{array}$

$\begin{array}{lr}\text { 2.2.4. Resistência } & 14\end{array}$

2.2.5. Métodos Rápidos de Identificação 15

$\begin{array}{ll}\text { 2.3. Aeromonas spp } & 16\end{array}$

$\begin{array}{ll}\text { 2.3.1 Caracterização } & 16\end{array}$

$\begin{array}{lr}\text { 2.3.2 Taxonomia } & 16\end{array}$

$\begin{array}{ll}2.3 .3 \text { Ocorrência } & 17\end{array}$

$\begin{array}{ll}\text { 2.3.4 Patogenia } & 21\end{array}$

2.3.5 Fatores de Virulência 23

2.3.6. Resistência a Agentes Antimicrobianos 25

$\begin{array}{ll}\text { 2.3.7 Plasmidios } & 28\end{array}$

3. OBJETIVOS 30

3.1 Objetivo Geral $\quad 30$

$\begin{array}{ll}\text { 3.2. Objetivos Específicos } & 30\end{array}$ 
4.1. Caracterização da Área de Estudo

4.2. Procedimento de Campo

4.3. Contagem de Coliformes Fecais e Presença de Escherichia coli 35

4.4. Ocorrência de Salmonella spp

4.4.1. Preparo das Amostras

4.4.2. Enriquecimento das Amostras

4.4.3. Isolamento do Microrganismo

4.4.4 Confirmação Molecular

4.4.5. Extração de DNA cromossômico de Cepas do Gênero 40 Salmonella Provenientes de Amostras de Água

4.4.6. Amplificação do DNA genômico de Salmonella spp a partir da Técnica da Reação em Cadeia da Polimerase (PCR)

4.4.7. Visualização de DNA genômico Extraído de Cepas do Gênero Salmonella spp

4.5. Ocorrência de Aeromonas spp

4.5.1. Enriquecimento das Amostras de Água 46

4.5.2. Enriquecimento das Amostras de Peixe 46

4.5.3. Isolamento do Microrganismo 47

4.5.4. Isolamento e Identificação das Colônias 47

4.5.5. Extração e Visualização do DNA plasmidial de Cepas do Gênero $\quad 50$ Aeromonas

4.6.1. Dados Secundários 53

4.6.2. Programa Estatístico e Nivel de Significância 54

5. RESULTADOS 
5.1. Contagem de Coliformes Fecais e Ocorrência de Escherichia coli e 55 Salmonella spp.

5.1.1. Confirmação Molecular de Cepas do Gênero Salmonella 57

5.1.2. Identificação do Gênero Salmonella a partir da Técnica da PCR $\quad 57$

5.2. Ocorrência de Aeromonas spp 60

5.2.1. Ocorrência de DNA Plasmidial em Cepas do Gênero Aeromonas 64

6. DISCUSSÃO 70

6.1. Enterobactérias 70

6.1.1. Coliformes fecais $\quad 70$

6.1.2. Escherichia coli 73

6.1.3. Salmonella spp 73

6.2. Aeromonas spp 76

6.2.1. Ocorrência 76

$\begin{array}{ll}\text { 6.2.2. Diversidade } & 78\end{array}$

6.2.6. Perfil Plasmidial $\quad 82$

6.3. Aspectos de Interesse em Saúde Pública 86

6.3.1. Qualidade da Água $\quad 86$

6.3.2. Qualidade do Peixe 90

6.3.3. Boas Práticas de Manipulação 93

$\begin{array}{ll}\text { 7. CONCLUSÕES } & 98\end{array}$

8. RECOMENDAÇÕES GERAIS 100

9. REFERENCIAS 101

GLOSSÁRIO

ANEXOS I, II, III, IV, V, VI, VII, VIII, IX 


\section{LISTA DE QUADROS}

Quadro 1: Características bioquímicas para identificação das espécies 49 do gênero Aeromonas

Quadro 2: Comportamento de cepas isoladas de água de pesqueiros, 58 caracterizadas por provas bioquímicas como Salmonella spp, frente a teste sorológico e PCR. 


\section{LISTA DE TABELAS}

Tabela 1: Distribuição do número e porcentagem de cepas de espécies 66 do gênero Aeromonas, segundo quantidade de plasmídios detectados 


\section{LISTA DE FIGURAS}

Figura 1: Visão geral de estabelecimentos tipo pesque-pague da 32 Região Metropolitana de São Paulo

Figura 2: Região Metropolitana de São Paulo com a localização dos 33 pesqueiros estudados (PREZOTTO e CABIANCA) (dados não publicados)

Figura 3: Esquema de análise para contagem de coliformes fecais pelo método do Número Mais Provável (NMP) e teste confirmativo de Escherichia coli.

Figura 4: Esquema geral de análise para detecção e confirmação, a partir de provas bioquímicas e sorológicas, do gênero Salmonella em amostras de água.

Figura 5: Esquema geral da extração de DNA genômico de cepas de Salmonella spp pelo método do choque-térmico

Figura 6: Esquema geral da amplificação e visualização de DNA genômico de cepas do gênero Salmonella pelas técnicas da PCR e eletroforese em gel de agarose

Figura 7: : Esquema geral de análise para detecção e identificação de Aeromonas spp, a partir de provas bioquímicas, em amostras de água e peixe

Figura 8: Esquema geral da extração de DNA plasmidial de cepas do gênero Aeromonas

Figura 9: Esquema geral das etapas necessárias para a visualização do DNA plasmidial extraído de cepas do gênero Aeromonas

Figura 10: Porcentagem de pesqueiros em desacordo com a legislação CONAMA No $20(01 / 06 / 86)$ para análise de coliformes fecais $\left(>10^{3} \mathrm{NMP}\right)$ e presença de $E$. Coli e Salmonella spp $(n=30)$, set/out2001- fev/mar2002

Figura 11: Porcentagem de pesqueiros em desacordo com os limites microbiológicos, segundo contagem de coliformes fecais e presença de Salmonella spp em amostras de água, dos períodos seco e chuvoso $(n=30)$, set/out2001- fev/mar2002

Figura 12: DNA genômico de cepas de Salmonella spp de amostras de água do período seco e chuvoso obtidos pela técnica de PCR. M1 e M2: Ladder $1 \mathrm{~kb}$; linha 1 - controle positivo para o gênero Salmonella; linha 2controle negativo; linhas 3,11 - cepas 7 e 31 ; linhas $4,5,6,7,8,9,10,12$ - 
cepas $39,67,69,99,105,109,148,40$

Figura 13: Porcentagem de pesqueiros, nos periodos seco e chuvoso, 60 segundo ocorrência de Aeromonas spp ( $n=30)$, set/out2001fev/mar2002

Figura 14: Diversidade de espécies do gênero Aeromonas isoladas de amostras de água e peixe de pesqueiros, no período seco e chuvoso $(n=30)$, set/out2001- fev/mar2002

Figura 15: Freqüência de ocorrência de cepas do gênero Aeromonas isoladas das amostras de água dos pesqueiros, no período seco e chuvoso $(n=30)$, set/out2001- fev/mar2002

Figura 16: Porcentagem de cepas do gênero Aeromonas isoladas das amostras de água dos pesqueiros, no período seco e chuvoso $(n=30)$, set/out2001- fev/mar2002

Figura 17: Freqüência de ocorrência de cepas do gênero Aeromonas isoladas das amostras de peixe dos pesqueiros, no periodo seco e chuvoso $(n=30)$, set/out2001- fev/mar2002

Figura 18: Porcentagem de cepas do gênero Aeromonas isoladas das amostras de peixe dos pesqueiros, no período seco e chuvoso $(n=30)$, set/out2001- fev/mar2002

Figura 19: Porcentagem de cepas de espécies do gênero Aeromonas com a presença de plasmídios, isoladas de amostras de água e peixe em ambos os períodos, out/nov2001 - fev/mar2002

Figura 20: Porcentagem de cepas de espécies do gênero Aeromonas com plasmídios isoladas de amostras de água e peixe de ambos os periodos out/nov2001 - fev/mar2002

Figura 21: Perfil plasmidial de cepas de Aeromonas spp isoladas de amostras de água e peixe dos períodos seco e chuvoso.M1. Hind III e M2: Ladder $1 \mathrm{~kb}$; $A$ : linhas $1,2,3,4,6$ - Aeromonas veroni sobria; linha 5 Aeromonas jandaei; linha 7 - Aeromonas trota; B: linhas 1, 2, 3, 4, 5, 6, 7 Aeromonas jandaei, C: linhas 1, 2, 3, 4, 5, 6, 7 - Aeromonas schubertii; D: Linhas 1, 2, 4, 5, 6 - Aeromonas trota; linha 3 - Aeromonas jandaei; linha 7 Aeromonas veroni sobria

Figura 22: Perfil plasmidial de cepas de Aeromonas spp isoladas de amostras de água e peixe dos períodos seco e chuvoso. M1: Hind III, M2: Ladder 1kb. A:1, 2-Aeromonas trota; 3, 4, 5, 6, 7, 8, 9-Aeromonas jandae; $\mathrm{B}: 1,2,3,4,5,6$-Aeromonas hydrophila; 7, 9-Aeromonas bestiarium; 8Aeromonas trota; linhas 10,11, 12, 13-Aeromonas jandaei; C:1, 2, 3, 4, 5, 8, 11 -Aeromonas bestiarium; $6,7,9,10,12$-Aeromonas hydrophila; D: 1, 2, 3, $4,5,6,7,8,9$-Aeromonas schubertii. 


\section{INTRODUÇÃO}

A pesca extrativista nacional que sempre foi apontada como a principal alavanca no desenvolvimento do setor pesqueiro, vem demonstrando sinais de estabilização ou mesmo de decréscimo. Apesar disso, um aumento na produção total brasileira pode ser observado (VENTURIERI 2002). Isso se deve sobretudo ao aumento da produção oriunda do cultivo de peixes, que vem crescendo em decorrência da demanda por parte da pesca recreativa, da qual fazem parte os sistemas do tipo pesque-pague, que por sua vez, está aliada à transformação que vem ocorrendo no novo espaço rural, onde atividades que eram exclusivamente agrícolas, passam a incorporar atividades não-agrícolas como a pesca recreativa, hotéis-fazendas etc (GRAZIANO DA SILVA 1999, KITAMURA e col. 1999).

No Brasil, essa atividade expandiu-se especialmente nas regiões sul e sudeste, com destaque para o Estado de São Paulo, cujo crescimento se deu principalmente na década de 90 . Estima-se atualmente que esse Estado contenha cerca de 1500 pesqueiros do tipo pesque-pague (KITAMURA e col. 1999, VENTURIERI 2002).

Segundo VENTURIERI (2002), os pesque-pague são locais particulares constituídos por lagos ou viveiros contendo, de forma artificial, peixes de várias espécies, disponiveis para a pesca. Nesse tipo de empreendimento o usuário, geralmente, paga pela entrada e mais um valor pelo quilo de peixe pescado. 
Os usuários podem ainda encontrar uma grande variação quanto ao porte, infra-estrutura (piscina, parque, churrasqueira), área hídrica para a pesca e oferta de serviços (restaurante, lanchonete) entre os pesque-pague, sendo desta forma, agrupados em quatro categorias. A categoria A é aquela que apresenta melhor oferta de serviços e infra-estrutura, a categoria D a que apresenta condições mínimas ou deficitárias para o exercício da atividade e as categorias B e C apresentam condições intermediárias entre as categorias citadas, sendo esta última, pior que a $B$ e melhor que a $D$.

Esse tipo de empreendimento normalmente são bastante procurados por pessoas e familias que buscam uma forma de aliviar as tensões e o estresse proporcionados pelos grandes centros urbanos (KITAMURA e col. 1999, LOVSHIN 2000, VENTURIERI 2002).

Por se tratar de uma atividade basicamente familiar constituída em grande parte por mão-de-obra não especializada (KITAMURA e col 1999) e por fornecer um produto direcionado ao consumo, os pesque-pague vêm sendo acompanhados de uma crescente preocupação higiênicosanitária, especialmente no que se refere à qualidade da água e do peixe dos pesqueiros.

De acordo com KITAMURA e col. (1999) a assistência técnica prestada por veterinários e biólogos aos pesqueiros ocorre de forma esporádica e somente para as questões sobre manejo de estoque e doenças em peixes.

No estudo de VENTURIERI (2002) com 250 pesqueiros do Estado de São Paulo, essa assessoria técnica não foi observada em $70 \%$ dos 
pesqueiros pertencentes à categoria $\mathrm{C}$, fator que se agrava quando aliado à ausência de funcionários treinados e, mesmo quando presentes, são na maioria das vezes, de baixa escolaridade, incluindo-se os proprietários dessa categoria.

Existe ainda a preocupação quanto ao consumo de peixes, pelo hábito de se comê-los crus, por influencia da culinária japonesa, cada vez mais presente no cardápio dos brasileiros, e ser este alimento responsável por incontáveis surtos de toxinfecções (GERMANO e col. 1993, MERINO e col. 1995, ALEXANDRINO de PEREZ 1998, ISONHOOD e DRAKE 2002).

Alguns pesqueiros servem o sashimi (finas fatias de peixe cru acompanhadas de molho de soja), motivo pelo qual são muito procurados pelos freqüentadores (VENTURIERI 2002).

A maioria dos usuários preocupa-se somente com a piscosidade dos lagos, não se importando com as condições do local, muitas vezes precárias (VENTURIERI 2002).

A questão legal também se apresenta bastante complexa. A regularização dos pesqueiros tipo pesque-pague no Estado de São Paulo responde as legislações federal, estadual e municipal, tais como o Instituto Brasileiro do Meio Ambiente e Recursos Naturais Renováveis (IBAMA), Departamento de Recursos Hídricos (DPRN), o Departamento de Águas e Energia Elétrica (DAEE), o Departamento do Uso do Solo Metropolitano (DUSM) e a Companhia de Tecnologia de Saneamento Ambiental (CETESB), além do Ministério da Agricultura e Abastecimento (VENTURIERI 2002). 
De acordo com a mesma autora, a relação entre essas instituições ou entre estas e sistemas pesque-pague é bastante desordenada, marcada pelo excesso de exigências e lentidão no processo de legalização. Essa dificuldade é a principal responsável para que mais de $90 \%$ não estejam legalizados.

Em face dessas informações e de existirem poucos relatos de abrangência nacional e internacional sobre questões de manejo, enfermidades e saúde pública em pesque-pague, o Instituto de Pesca da Secretaria da Agricultura - SP, o Instituto de Botânica da Secretaria do Meio Ambiente - SP, a Faculdade de Medicina Veterinária da USP, juntamente com o Laboratório de Saúde Pública da Faculdade de Saúde Pública da USP elaboraram um projeto de pesquisa intitulado, "Diagnóstico ecológicosanitário de pesqueiros da região metropolitana de São Paulo", com a proposta de realizar um levantamento das condições físicas, químicas e biológicas das águas e peixes, além da caracterização do entorno dos lagos.

Dessa forma, o presente trabalho pretendeu avaliar a qualidade microbiológica da água através da pesquisa de bactérias indicadoras de contaminação fecal, além da investigação de bactérias potencialmente patogênicas do gênero Aeromonas em amostras de água e peixe dos pesqueiros. 


\section{ANÁLISE DE LITERATURA}

\subsection{Coliformes fecais e Escherichia coli}

A pesquisa do grupo dos coliformes fecais é tradicionalmente empregada, sobretudo em saúde pública, como indicador microbiológico das condições higiênico-sanitárias de uma amostra, seja ambiental ou de alimento, uma vez que os coliformes são preferencialmente encontrados no trato gastrintestinal de humanos e outros animais de sangue quente, sendo capazes de fornecer informações sobre a ocorrência de contaminação fecal recente (GAUTHIER e ARCHIBALD 2001, NOBLE e col. 2003, NEILL 2004, WEBSTER e col. 2004).

O mesmo significado pode ser atribuido à espécie Escherichia coli (E. coli), que faz parte do grupo dos coliformes fecais; porém, com um diferencial que a torna uma indicadora de contaminação fecal ainda mais específica, exatamente por ser encontrada quase que exclusivamente no trato gastrintestinal desses animais, compreendendo cerca de $97 \%$ do total dos organismos aeróbios encontrados em fezes humanas e $90 \%$ a $100 \%$ em 8 espécies de animais domésticos. Dessa maneira, esses indicadores são incapazes de se multiplicarem no ambiente aquático na ausência de um hospedeiro (APHA 1995, ASHBOLT e col. 2001, AN e col. 2002, NEILL 2004). 


\subsubsection{Ocorrência}

Em ambientes aquáticos, os coliformes fecais e $E$. coli são comumente utilizados como indicadores de contaminação fecal, motivo de atenção em saúde pública.

NOBLE e col. (2003), testando a qualidade microbiológica de águas salgadas destinadas à recreação, encontraram coliformes fecais em quantidades superiores a $400 \mathrm{NMP} / 100 \mathrm{~mL}$. No ambiente estuarino, esses indicadores também foram estudados, onde foi possivel verificar seu comportamento frente aos diferentes niveis de salinidade do local (NEILL 2004).

Em relação aos ecossistemas de água doce, especialmente aqueles direcionados a recreação, onde são praticadas atividades de lazer, as águas são mais susceptiveis a contaminação fecal (CRABILL e col. 1999, ALM e col. 2003).

CRABILL e col. (1999), estudando o impacto dos coliformes fecais nas águas do Rio Oak Creek, Arizona (EUA) verificaram altas contagens desses organismos, principalmente no sedimento desse ecossistema.

Resultados similares também foram observados por AN e col. (2002) nas águas do Lago Texoma, localizado próximo a Oklahoma e Texas (EUA) e ALM e col. (2003), nas águas do Lago Huron e do Rio St. Clair, Michigan (EUA).

Estudos realizados com o sedimento de lagos e lagoas, demonstraram seu papel como um potencial risco poluidor, uma vez que 
funcionam como importantes reservatórios das bactérias fecais que permanecem nesse local por um certo período de tempo (CRABILL e col. 1999, AN e col. 2002, ALM e col. 2003).

MENON e col. (2003) estudaram a ocorrência de bactérias autóctones e fecais, dentre elas $E$. coli, no Rio Sena (França), bem como as suas taxas de mortalidade em diferentes periodos do ano.

PIANETTI e col. (2004) também isolaram coliformes fecais na maioria das amostras coletadas em vários pontos do Rio Giovenco (Itália) destinado principaimente à irrigação e abastecimento.

Na piscicultura, EL-SHAFAl e col. (2004) e AL-HARBI e UDDIN (2004) observaram a ocorrência de indicadores fecais nas águas dos viveiros, bem como a sua influência sobre a qualidade microbiológica de tilápias (Oreochromis niloticus) ali presentes.

\subsubsection{Qualidade da Água}

Uma prática comumente empregada na piscicultura, principalmente em paises asiáticos, é o lançamento de esgoto doméstico ou dejetos de animais nos tanques de peixes, com a finalidade de promover 0 aumento natural da produtividade primária e secundária dos viveiros (EASA e col. 1995, SHEREIF e col. 1995, RIBEIRO e col. 1997, BACK e col. 1998, EL-SHAFAl e col. 2004).

De acordo com os mesmos autores, em alguns paises essa prática é combatida para que se evite risco à saúde dos consumidores. 
Em Santa Catarina, a mesma forma de incremento com dejetos de animais foi praticada em viveiros de produção artificial de peixes, nos quais BACK e col. (1998) puderam pesquisar a qualidade microbiológica das águas submetidas a três formas de adubação: de marreco, ração e de suíno.

A manutenção de uma boa qualidade microbiológica das águas é fundamental para que o sistema imunológico dos peixes não seja prejudicado, uma vez que águas muito poluidas e com elevada carga microbiana, revelam-se como um ambiente muito estressante para esses animais que acabam tornando-se mais susceptiveis as infecções sobretudo microbianas. Estes microrganismos aproveitam-se da vulnerabilidade dos peixes, ultrapassando seus diversos mecanismos de defesa, conseguindo, com isso, penetrar em vários órgãos e até mesmo no tecido muscular desses animais (POLPRASERT e col. 1984, MARA e CAIRNCROSS 1989, OGBONDEMINU e OKOYE 1992, FATALL e col.1993, EASA e col. 1995, EL-SHAFAl e col. 2004, GUZMÁN e col. 2004).

\subsubsection{Patogenia}

O grupo dos coliformes fecais não é formado apenas pela Escherichia coli, mas por outros gêneros de bactérias, que assim como a $E$. coli, pertencem, em sua maioria, à família Enterobacteriaceae, o qual são importantes pela sua implicação em saúde pública (D'AOUST 1997, ASHBOLT e col. 2001, GAUTHIER e ARCHIBALD 2001). 
A espécie Escherichia coli é uma das bactérias mais conhecidas e estudadas até o momento. é constituída por uma variedade relativamente grande de bactérias patogênicas ao homem e outros animais. Podem causar infecções intestinais e urinárias, septicemias, meningites entre outros tipos de infecção (DOYLE e col. 1997, KONEMAN e col. 2001).

Dentre as $E$. coli causadoras de gastrenterites, estas podem ser divididas em quatro grupos de acordo com seus mecanismos patogênicos: E. coli enterotoxigênica (ETEC), E. coli enteropatogênica (EPEC), E. coli enteroinvasora (EHEC) e E. coli enteroagregativa (EaggEC) (KONEMAN e col. 2001).

As cepas enterotoxigênicas são responsáveis pela produção de enterotoxinas termoestáveis, causadoras da diarréia secretora (diarréia dos viajantes). Sua infeç̧ão pode ocorrer pela ingestão de água ou alimento contaminado (KONEMAN e col. 2001).

As cepas enteropatogênicas aderem às células do epitélio causando inflamação e lesões degenerativas. A doença é caracterizada por febre, vômitos e diarréia (KONEMAN e col. 2001).

As $E$. coli enteroagregrativas também se aderem às células intestinais, causando diarréia aquosa, vômitos e dor abdominal (KONEMAN e col. 2001).

As cepas enteroinvasoras penetram nas células epiteliais, provocando diarréia inflamatória com presença de sangue nas fezes e as $E$. coli enterohemorrágicas, também podem produzir diarréia sanguinolenta, porém, em decorrência da produção de toxinas (KONEMAN e col. 2001). 
Esses organismos, responsáveis por inúmeros casos de doenças nos seres humanos são uma grande preocupação para as autoridades. Entre 1999 a 2000, 59 surtos registrados nos Estados Unidos foram atribuidos a águas recreacionais, dos quais $61 \%$ estavam relacionados a casos de gastrenterites (CDC 2002).

Outro fator importante refere-se à resistência dessas bactérias, alóctones do ambiente aquático, a determinados produtos antimicrobianos lançados no meio hídrico como os desinfetantes, descritos por GAUTHIER e ARCHIBALD (2001).

WEBSTER e col. (2004) observaram a presença de cepas de $E$. coli resistentes à penicilina em águas do Rio Okatee (EUA) próximo à zona rural.

\subsection{Salmonella spp}

\subsubsection{Taxonomia}

As bactérias do gênero Salmonella são bacilos gram-negativos e pertencem à familia Enterobacteriaceae. São móveis, não produtoras de esporos, anaeróbios facultativos, capazes de reduzir nitratos e nitritos, além de fermentarem a glicose e não possuírem citocromo oxidase.

O gênero Salmonella constitui o grupo mais complexo da familia das Enterobacteriaceae, sendo que sua nomenclatura já sofreu várias modificações e ainda permanece instável. No momento atribuem-se ao 
gênero Salmonella apenas duas espécies: S. enterica, subdividida em seis subespécies e S. bongori (ELZÉBY 1999, POPOFF e col. 2003).

Dentre as subespécies de $S$. enterica subsp. enterica, destacamse a Salmonella enterica subsp. enterica sorotipo Enteritidis (Salmonella Enteritidis) e Salmonella enterica subsp. enterica sorotipo Typhimurium (Salmonella Typhimurium) (ELZÉBY 1999, YAN e col. 2003).

\subsubsection{Ocorrência}

As bactérias do gênero Salmonella são amplamente distribuidas na natureza, porém são preferencialmente localizadas no trato intestinal de animais (ratos, lagartos, serpentes, aves, bovinos, cães, suínos, gatos etc) e de seres humanos (KONEMAN e col. 2001, YAN e col. 2003), podendo também infestar o trato digestório de peixes (OGAWA e MAIA 1999).

Nesse sentido são comumente encontradas em esgoto e efluentes, podendo, com isso, contaminar com facilidade as águas destinadas à recreação (POLO e col. 1998).

ARVANITIDOU e col. (1997) isolaram 79 cepas de Salmonella spp provenientes de rios e lagos localizados na região nordeste da Grécia, as quais foram submetidas a testes com diversos antimicrobianos.

POLO e col. (1998), pesquisando a ocorrência do gênero Salmonella em diversos ecossistemas aquáticos, isolaram esse patógeno em amostras provenientes de praias, rios e reservatórios de água doce. 
PIANETTI e col., em 1998, verificaram a ocorrência de Salmonella spp no Rio Foglia (Itália), além da sua relação com os indicadores fecais.

MENON e col. (2003) observaram cepas de Salmonella spp em amostras de água coletadas do Rio Sena (França) e as principais causas envolvidas com a morte dessas bactérias nesse tipo de ambiente.

Em um outro momento, PIANETTI e col. (2004) isolaram Salmonella spp em dois pontos ao longo do Rio Giovenco (Itália).

O gênero Salmonella também foi encontrado em peixes mantidos em aquários (SEEPERSADSINGH e ADESIYUN 2003 e SENANAYAKE e col. 2004).

\subsubsection{Patogenia}

A importância de Salmonella spp como causadora de doenças, principalmente as de origem alimentar, continua sendo intensamente relatada na maior parte do globo, especialmente em países onde as condições higiênico-sanitárias são precárias e a manipulação de alimentos é realizada de maneira inadequada. É considerado um dos principais patógenos causadores de gastrenterites em seres humanos (POLO e col. 1998, AGARWAL e col. 2002, SEEPERSADSINGH e ADESIYUN 2003).

É importante ressaltar que as salmoneloses também podem ser provocadas por animais selvagens ou domésticos, incluindo cães, gatos, 
aves, roedores e répteis. Estima-se que $90 \%$ dos répteis abrigam Salmonella spp em seu intestino. Os peixes podem excretar Salmonella em suas fezes sem apresentarem qualquer sintoma de comprometimento (SEEPERSADSINGH e ADESIYUN 2003, YAN e col. 2003, SENANAYAKE e col. 2004).

As infecçōes humanas ocorrem em geral pela ingestão de água e alimentos contaminados por fezes humanas ou de animais, ou até mesmo pelo contato direto com animais infectados. De acordo com RIVERA e MARTINS (1996), infecções por Salmonella também podem ser adquiridas em águas recreacionais.

Nos Estados Unidos cerca de 1,5 milhões de novos casos de infeç̧ões por Salmonella spp são notificados anualmente (YAN e col. 2003).

O quadro clínico mais comum de salmoneloses envolve sintomas de gastrenterites: náusea, vômito e diarréia na presença ou ausência de febre. Em uma pequena porcentagem $(<5 \%)$ dos pacientes, a doença evolui para além do trato intestinal, como bacteremia, e 5 a $10 \%$ desenvolvem infecções localizadas (YAN e col. 2003).

SENANAYAKE e col. (2004) recentemente notificaram um caso de salmonelose na Austrália envolvendo uma criança que havia entrado em contato com peixes tropicais mantidos em aquários. O paciente apresentou diagnóstico positivo para Salmonella enterica subsp enterica sorotipo Paratyphi B. 


\subsubsection{Resistência}

O crescente número de bactérias resistentes aos agentes antimicrobianos, tais como, pesticidas, metais pesados e, sobretudo, antibióticos têm cada vez mais preocupado as autoridades de saúde pública. As bactérias resistentes, patogênicas aos homens e aos animais, continuam emergindo e desafiando, cada vez mais, as medidas direcionadas ao controle e tratamento das doenças infecciosas provocadas por esses microrganismos (DEFRANCESCO e col. 2004). O uso indiscriminado de drogas antimicrobianas empregadas no tratamento de doenças em seres humanos e na prevenção de enfermidades em animais funciona como um dos principais elementos responsáveis pela seleção das bactérias mais resistentes (DEFRANCESCO e col. 2004).

ARVANITIDOU e col. (1997) testando a resistência de 79 cepas de Salmonella spp, provenientes de amostras de rios e lagos ao norte da Grécia, frente a 20 tipos de antibióticos, observaram que algumas cepas mostraram-se resistentes a um ou mais tipos de antibióticos.

YAN e col. (2003) verificaram que as bactérias do gênero Salmonella mostraram-se resistentes a vários agentes antimicrobianos.

Esses genes de resistência tem sido identificados em diversas bactérias Gram-negativas isoladas de esgoto, rios e águas de abastecimento. Esse fato pode ser atribuído à alta taxa de transferência de genes plasmidiais ocorrida entre elas, responsável pelo aumento da 
variabilidade genética e, portanto, de sua adaptabilidade (ARVANITIDOU e col. 1997, DEFRANCESCO e col. 2004).

\subsubsection{Métodos de Identificação}

A detecção e identificação do gênero Salmonella ainda é realizada, sobretudo, a partir de métodos tradicionais de bacteriologia, como os testes bioquímicos e sorológicos. O primeiro consiste na diferenciação em espécies distintas a partir da habilidade, de cada uma delas, fermentarem uma grande variedade de carboidratos selecionados. O segundo consiste no emprego de diferentes anti-soros conhecidos, a partir dos quais a bactéria aglutina quando misturada a anticorpos que são produzidos em resposta àquela espécie ou gênero, configurando, desta forma, um resultado positivo.

Em geral, esses testes demandam no minimo 5 dias para a confirmação do resultado. Nesse sentido, a metodologia clássica para amostras de alimentos, clínicas ou ambientais, vem sendo substituida, cada vez mais, por métodos muito mais rápidos e precisos como, por exemplo, o emprego da técnica da Reação em Cadeia da Polimerase (PCR), que consiste na amplificação de um determinado segmento de DNA, por meio de uma enzima denominada DNA-polimerase, obtendo-se com isso, inúmeras cópias da seqüência alvo de DNA de forma que se torna detectável, por coloração, após a separação pela eletroforese em gel. Deste modo, esta técnica permite que sejam evitados resultados falso-positivos, sendo estes mais freqüentes nos métodos tradicionais (AABO e col. 1993, 
JITRAPAKDEE e col. 1995, GOODING e CHOUDARY 1999, SOUMET e col. 1999, TOZE 1999 e AGARWAL e col. 2002).

\subsection{Aeromonas spp}

\subsubsection{Caracterização}

O gênero Aeromonas é composto por bacilos gram-negativos e suas células apresentam morfologia que varia do cocóide ao bacilar. Podem medir de 1,0 a $3,5 \mathrm{~mm}$ de comprimento e 0,3 a $1,0 \mathrm{~mm}$ de largura. Possui espécies imóveis e móveis por flagelo polar; são fermentadoras; anaeróbias facultativas e apresentam positividade à reação de oxidase, que as distingue das enterobactérias. Crescem em ambientes com salinidade de até $4 \%, \mathrm{pH}$ entre 5,5 a 9,0 e temperaturas que podem variar de 0 a $41^{\circ} \mathrm{C}$ (POPOFF 1984, COLWELL e col. 1986, HOLMES e col. 1996, HUYS e col. 1997).

\subsubsection{Taxonomia}

Desde a sua descoberta, o gênero Aeromonas tem sido caracterizado como um grupo de posição taxonômica pouco estável. Inicialmente pertenceu a família Pseudomonadaceae, de acordo com a $7^{\mathrm{a}}$ edição do "Bergey's Manual of Systematic Bacteriology" de 1957. Na $8^{a}$ edição (SCHUBERT 1974) foi classificado como pertencente à família Vibrionaceae e atualmente compreende a família Aeromonadaceae proposta 
por COWELL e col. (1986) e já disponivel no "Taxonomic Outline of the Procaryotic Genera Bergey`s Manual of Systematic Bacteriology" (GARRIT e col. 2001).

A identificação de Aeromonas spp também não é um procedimento muito fácil, uma vez que as espécies compartilham semelhanças fenotípicas entre elas. Por esse motivo, alguns pesquisadores estão associando métodos moleculares às técnicas bioquímicas (DORSCH e col. 1994, JANDA e col. 1996, KAZNOWSKI 1998, ABBOTT e col. 2003).

Dentre as espécies de Aeromonas, as descritas e validadas são : A. hydrophila, A. salmonicida, A. media, A. encheleia, A. allosaccharophila, A. eucrenophila, A. bestiarum, A. caviae, A. veronii biogrupo sobria, A. veronii biogrupo veronii, $A$. schubertii, A. jandaei, A. trota, A. popoffii, $A$. culicicola, A. simiae e A. molluscorum (ALLEN e col. 1983, POPOFF 1984, HICKMAN-BRENNER e col. 1987, HICKMAN-BRENNER e col. 1988, SCHUBERT e HEGAZI 1988, CARNAHAN e col. 1991a, CARNAHAN e col. 1991b, MARTINEZ-MURCIA e col. 1992, ESTEVE e col. 1995, ALI e col. 1996, HUYS e col. 1997, PIDIYAR e col. 2002, HARF-MONTEIL e col. 2004, MIÑANA-GALBIS e col. 2004). Além dessas já validadas, MATTÉ e col., em 1999, descreveram outra espécie nomeada como Aeromonas arequipensis.

\subsubsection{Ocorrência}

As Aeromonas spp ocorrem com grande freqüência nos ecossistemas aquáticos, uma vez que constituem a microbiota desse tipo de 
ambiente, mas têm grande facilidade de sobreviver em diversos outros locais como o solo (KHARDORI e FAINSTAIN 1988, MATTÉ 1995, BRANDI e col. 1996).

Sua ampla distribuição deve-se à sua alta capacidade de se multiplicar, independente de um hospedeiro, humano ou mamífero (KHARDORI e FAINSTAIN 1988, KIROV 1993).

$\mathrm{Na}$ água doce existem muitos estudos com esse grupo de microrganismos. MATTÉ (1995) isolou 4 espécies de Aeromonas na represa de Guarapiranga-SP, tanto de amostras da superficie da água quanto de sedimento. FALCÃO e col. (1998) pesquisando em águas de rios, represa e de irrigação em Araraquara-SP, isolaram 3 espécies de Aeromonas. GIBOTTI e col. (2000) isolaram 32 cepas de Aeromonas de 70 amostras de água em diversos pontos de coleta do Ribeirão Cambé, Londrina-PR. Cabral (2000) estudando a diversidade desse grupo em diferentes corpos d'água no Estado de São Paulo, confirmou 294 cepas como pertencentes ao gênero Aeromonas, ocorridos nas amostras dos seguintes locais: rio Tietê no município de Salto; rios Ribeirão, Betari e Ribeira do Iguape, cavernas Santana e Água Suja, todos da cidade de Iporanga; Prainha e posto da Sabesp da Represa Billings. RAZZOLINI (1998) isolou espécies de Aeromonas procedentes de bebedouros e caixas d'água em algumas regiões de São Paulo. IVANOVA e col. (2001), estudando água de abastecimento próximo à cidade de Vladivostok (Rússia) registraram pela primeira vez a ocorrência desse gênero naquela região. ROCHA (2004) 
isolou o gênero Aeromonas em lagoas de estabilização e unidade de desinfecção por hipoclorito de sódio no municipio de Lins-SP.

Na água salobra, salgada e de esgoto tratada e não tratada, Aeromonas spp também pode ocorrer, embora em proporção um pouco menor. A água poluida pode representar uma via de contaminação para as águas superficiais que são utilizadas para fins recreacionais. A presença deste microrganismo é favorecida pelo conteúdo de matéria orgânica presente na água, portanto sua sobrevivência é aumentada em águas poluidas e com descarga de esgotos (MATTÉ 1995, ESTEVE e col. 1995, HOLMES e col. 1996, KIROV 1997, SORIANO e col. 2000).

Aeromonas spp também são contaminantes comuns de anfíbios, répteis, frutos do mar, mamiferos, aves e peixes (JOSEPH e CARNAHAN 1994, ALEXANDRINO de PEREZ e col. 2000, HUYS e col. 2003).

HÄNNINEN e col. (1997) identificaram Aeromonas spp em 27 de 29 amostras de peixe que pesquisaram. RALL e col. (1998), encontraram, pelo método de presença e ausência, 3 espécies de Aeromonas em peixes "Pintado" (Pseudoplatystoma sp).

GONZÁLEZ e col. (2001) documentaram a ocorrência de seis espécies do gênero Aeromonas em peixes pertencentes às espécies Oncorhynchus mykiss provenientes de sistemas de cultivo de Salmo trutta e Esox lucius em águas do Rio León (Espanha). Os autores observaram também o comportamento de quatro espécies do gênero Aeromonas, isoladas da pele, musculatura e da cavidade abdominal dos peixes, durante o acondicionamento em gelo. 
GONZÁLES-RODRÍGUEZ e col (2002), estudando 12 lotes de filés frescos de truta arco-iris (Oncorhynchus mykiss) e 10 lotes de pedaços de salmão (Salmo salar) mantidos a $3^{\circ} \mathrm{C}$, conseguiram isolar espécies de Aeromonas de ambas as amostras.

CASTRO-ESCARPULLI e col., em 2003, isolaram cepas de Aeromonas spp em tilápias (Oreochromis niloticus niloticus) comercializadas em mercados da Cidade do México, identificando várias espécies, tais como: A. salmonicida, $A$. bestiarium, $A$. veronii veronii, $A$. encheleia e, numa proporção menor, A. hydrophila.

AL-HARBI e UDDIN (2004) observaram a ocorrência de Aeromonas hydrophila como parte da flora intestinal de tilápias hibridas cultivadas em tanques da Arábia Saudita.

HATHA e col., em 2004, documentaram o predomínio de cepas pertencentes ao gênero Aeromonas em três espécies de peixes de água doce provenientes de viveiros da Índia a saber: Catla catla, Labeo rohita e Ctenopharyngodon idella.

Além da ocorrência desse patógeno em peixes, foi detectada a presença de A. caviae em $78 \%$ das moscas domésticas (Musca domestica) provenientes de bovinos e restaurantes (NAYDUCH e col. 2001).

MESSI e col. (2002), relataram o isolamento do gênero Aeromonas em 2 dos 20 poços de água estudados.

A ocorrência de Aeromonas caviae, A. hydrophila e A. schubertii em queijo-de-minas frescal artesanal também foi observada por BULHŐES e ROSSI Jr (2002). 
SOLER e col. (2002), isolaram 72 cepas de Aeromonas spp de água de reservatórios e rios e 30 de água do mar. Em amostras de água doce as espécies mais freqüentes foram $A$. veronii, $A$. hydrophila e $A$. caviae, enquanto que em água salgada, $A$. caviae foi a mais freqüente.

GRASSI e col. (2003), estudando a presença de Aeromonas spp em alimentos crus, processados e prontos para consumo, encontraram 21 cepas em carnes de origem bovina, 16 em carnes de aves, 7 em peixes e 18 em queijos. Do total dos isolados, $65 \%$ foram identificadas como $A$. hydrophila e A. caviae e $20 \%$ como A. veronii sobria.

VILA e col. (2003), estudando a prevalência de Aeromonas spp associada à diarréia dos viajantes, isolaram as seguintes espécies: $A$. veronii sobria, A. caviae, A. jandaei e A. hydrophila, embora tenham observado associação mais significativa com as duas primeiras.

Cepas de Aeromonas spp também foram encontradas, embora em pequenas quantidades, de vegetais minimamente processados, como alface, cenoura e pimenta (UYTTENDAELE e col. 2004).

\subsubsection{Patogenia}

Assim como para as bactérias indicadoras, a pesquisa de cepas ambientais é muito importante, uma vez que podem estar relacionadas a diversas enfermidades que acometem o homem (PIANETTI e col. 2004).

O gênero Aeromonas foi descrito como patógeno emergente pela Organização Mundial da Saúde (OMS) e pela Agência de Proteção 
Ambiental (EPA) dos Estados Unidos e tem recebido especial atenção, nos últimos anos, por estar com várias doenças em humanos e outros animais, e na maioria dos casos de gastrenterites. (MERINO e col. 1995, PIANETTI e col. 1998, RALL e col. 1998, BORCHARDT e col. 2003, GRASSI e col. 2003, PIANETTI e col. 2004, WARREN e col. 2004).

Foi sugerido pela Agência de Proteção Ambiental (EPA) que a pesquisa de Aeromonas hydrophila em água de abastecimento faça parte do novo regulamento de proteção a saúde pública contra os riscos associados a água de abastecimento, devido a sua facilidade de se desenvolver no sistema de distribuição de água, em especial, como biofilmes, formas mais resistente à ação do cloro (SOLER e col. 2002, BORCHARDT e col. 2003).

De acordo com ALEXANDRINO de PEREZ e col. (2000), a aeromonose é bastante comum em cultivos intensivos, principalmente onde a população íctiica ultrapassa a capacidade ideal proporcionada pelas lagoas, ou seja, quando mantida em condições estressantes.

Esse gênero têm sido freqüentemente isolado de pacientes com gastrenterites, embora seu papel ainda esteja pouco esclarecido. As formas móveis estão associadas principalmente à diarréia autolimitante e a colérica. Além disso, podem estar relacionadas a infecçōes de pele, ouvido, casos de necrose e septicemia, envolvendo pacientes portadores de cortes, perfurações e distúrbios imunológicos. (HOUSTON e col.1991, JANDA e col. 1996, ABBOT e col. 2003). 
As espécies associadas principalmente a gastrenterites são: $A$. caviae, A. hydrophila e A. veronii biotipo sobria (JOSEPH 1996); sendo a A. caviae mais freqüente em crianças com menos de 3 anos de idade.

Existe divergência entre os autores sobre o significado clínico do isolamento de Aeromonas spp, no trato intestinal, uma vez que para ALTWEGG e GEISS (1989) a frequiência dos isolados é semelhante entre adultos sintomáticos e assintomáticos, enquanto que JOSEPH (1996) revela correlação significativa entre diarréia e produção de enterotoxinas produzidas por Aeromonas spp.

Nos últimos dez anos, diversos casos de gastrenterite provocados por Aeromonas spp vêm sendo registrados, e entre esses eventos, um episódio ocorrido na Itália, envolvendo consumo de queijo tipo mussarela, determinou a morte do paciente (GRASSI e col. 2003).

\subsubsection{Fatores de Virulência}

A patogenicidade apresentada pelo gênero Aeromonas está associada à presença dos vários fatores de virulência, tais como endopeptidases, proteinases, hemolisinas $\alpha$ e $\beta$, fimbrias, adesinas não filamentosas (KIROV 1997), enterotoxinas citolíticas e enterotoxinas citotóxicas (KIROV e col. 1999), e ocorrência de plasmídios de tamanho variável (BROWN e col. 1997); que dependendo da atuação, em conjunto ou isolados, podem provocar graves conseqüências ao hospedeiro. 
No estudo de BAUAB e col. (2001) com marcadores de virulência em cepas de Aeromonas spp, isoladas de materiais clínicos de humanos sem sintomas e de água doce, os autores concluiram que a correlação foi pouco significativa entre a ocorrência de fatores de virulência e o tipo de material clínico, enquanto que, o contrário foi observado entre presença de citotoxinas e infecções extra-intestinais e enterotoxinas e fezes diarréicas.

SCOGLIO e col. (2001) estudando fatores de virulência em $A$. caviae e A. hydrophila isoladas de amostras de frutos do mar, detectaram que todas as cepas foram positivas para lipase e para a propriedade de aderência às células do epitélio de mamiferos. A espécie $A$. hydrophila foi sempre positiva para DNase e caseinase. Para a produção de hemolisina, $A$. hydrophila foi $\beta$-hemolítica, enquanto que $A$. caviae, $\alpha$-hemolítica. Para atividade citotóxica, $A$. caviae foi negativa e $A$. hydrophila positiva.

MARTINS e col. (2002) estudaram a prevalência de Aeromonas spp em infecções humanas e em alimentos, utilizando para a identificação das espécies a classificação de POPOFF (1984). Os autores verificaram que $46(24 \%)$ das Aeromonas spp isoladas produziam enterotoxinas. A espécie produtora de enterotoxina mais freqüente em amostras clinicas foi $A$. veronii e a mais isolada de amostras de alimentos foi $A$. sobria. A. jandaei e $A$. schubertii produziram pouca quantidade ou nenhuma enterotoxina. Em relação à atividade hemolítica, todas as cepas isoladas produziram hemolisina quando semeadas em Ágar sangue de carneiro (SBA). A espécie hemolítica com maior ocorrência em amostras clínica e de alimentos foi $A$. veronii (70\%). Para a atividade citotóxica, das 194 Aeromonas spp isoladas, 
$157(89 \%)$ produziram citotoxinas, $A$. veronii $(89 \%)$, A. sobria $(88 \%), A$. salmonicida ( $86 \%)$. A. caviae $(86 \%)$ foi a espécie que apresentou maior atividade. A. jandaei, ao contrário, não mostrou atividade citotóxica.

RADU e col. (2003) isolaram A. veronii sobria, A. hydrophila e A. caviae isoladas de amostras de peixe, as quais $90 \%$ foram positivas para atividade hemolitica.

PIANETTI e col., em 2004, observaram a presença de fatores de virulência como adesinas e citotoxinas muito mais freqüentes nas espécies A. hydrophila e A. veronii sobria do que em A. caviae.

\subsubsection{Resistência a Agentes Antimicrobianos}

O uso indiscriminado de antibióticos no tratamento de infecções bacterianas em animais, tem resultado num aumento global de bactérias patogênicas resistentes a antibióticos. O problema é maior entre paises em desenvolvimento, onde seu uso é generalizado (VIVEKANANDHAN e col. 2002).

O uso desses agentes antimicrobianos é o fator mais importante responsável pela amplificação dos niveis de resistência das bactérias patogênicas presentes num dado reservatório (MICHEL e col. 2003).

Na aqüicultura o uso dos agentes antimicrobianos é bastante difundido, no mundo todo, para tratamento de infecções causadas por uma variedade de bactérias patogênicas para os peixes, dentre elas, Aeromonas hydrophila e Aeromonas salmonicida (CDC 1999, LALUMERA e col. 2004). 
$\mathrm{Na}$ Índia, antibióticos são extensamente aplicados a agricultura e aqüicultura (VIVEKANANDHAN e col. 2002).

No mínimo $75 \%$ dos antibióticos presentes na alimentação dos peixes, provenientes do sistema aqüícola, atingem o meio ambiente, com posterior acúmulo nos sedimentos desses corpos d'água (LALUMERA e col. 2004).

ERVIK e col. (1994) relataram que bactérias, resistentes a antibióticos usados numa determinada propriedade de piscicultura, foram isoladas do conteúdo estomacal dos peixes; enquanto que em áreas que não receberam o tratamento, isso não foi verificado.

RADU e col. (2003) estudando espécies de Aeromonas em amostras de peixe provenientes de mercado, verificaram que todas as cepas isoladas exibiram resistência a ampicilina, carbenicilina, eritromicina e estreptomicina em associação a outros agentes antimicrobianos.

Num estudo conduzido por URRIZA e col. (2000), verificou-se que 99\% das Aeromonas spp apresentaram-se resistentes a ampicilina.

A resistência múltipla a antibióticos entre Aeromonas hydrophila tem sido registrada em várias partes do mundo (SON e col.1997).

Na pesquisa de VIVEKANANDHAN e col. (2002) com cepas de $A$. hydrophila isoladas de amostras de peixe e camarão, no sul da Índia, verificaram que todas as cepas foram resistentes a meticilina e $95 \%$ resistentes a bacitracina, eritromicina, neomicina, novobiocina, polimixina-B e rifampicina. Uma resistência menor foi observada para cloranfenicol $(3,7 \%)$, gentamicina $(7,5 \%)$, estreptomicina $(8,7 \%)$ e ácido nalidíxico 
$(16,9 \%)$. Aproximadamente $51,4 \%$ das cepas foram resistentes à tetraciclina. A diferença em relação à resistência a antibióticos entre cepas de peixe e de camarão foi mínima.

Em muitos países $A$. salmonicida tem sido relatada como resistente a múltiplas drogas como sulfonamidas, tetraciclina, amoxicilina, trimetoprim-sulfadimetoxina e quinolonas (INGLIS e col. 1993, BARNES e col. 1994, DALSGAARD e col. 1994), antibióticos comumente encontrados na aqüicultura.

MICHEL e col. (2003) observaram, na França, que cepas de $A$. salmonicida mostraram-se resistentes ao cloranfenicol utilizados durante muito tempo em pisciculturas.

De acordo com LALUMERA e col. (2004), os antibióticos mais comumente empregados no tratamento das doenças como furunculose, causada por $A$. salmonicida e que freqüentemente acometem os peixes originários da produção aqüícola italiana são: amoxicilina, flumequina, oxitetraciclina, sulfamerazina e tianfenicol.

Os autores alertaram também sobre o acúmulo, principalmente de flumequina e oxitetraciclina, nos sedimentos das pisciculturas, mesmo após dois anos e oito meses da aplicação. Essas substâncias foram igualmente observadas em sedimentos de corpos d'água próximos às pisciculturas, decrescendo as concentraçōes com o distanciamento em relação aos viveiros.

CASTRO-ESCARPULLI e col. (2003) verificaram que todas as cepas de Aeromonas spp pesquisadas, mostraram-se resistentes a $\beta$ - 
lactamase, com exceção a piperacilina $(19,4 \%)$ e a segunda e terceira geração de cefalosporinas (cefuroxima e cefotaxima). As cepas de $A$. salmonicida isoladas de diferentes áreas geográficas apresentaram uma sensibilidade decrescente aos antibióticos: ampicilina, cloranfenicol, neomicina, polimixina $\mathrm{B}$ e rifampicina. Os resultados revelaram também que - gênero Aeromonas mostrou-se mais sensivel à primeira geração de quinolonas e segunda e terceira geração de cefalosporina.

A permanência dessas bactérias no meio aquático é uma preocupação para as autoridades de saúde pública que vêem a saúde dos seres humanos e dos animais expostos ao risco de se contaminarem com esses microrganismos cada vez mais resistentes às substâncias antimicrobianas, dificultando, com isso, os tratamentos a serem empregados.

\subsubsection{Plasmídios}

Os plasmídios são elementos circulares extra-cromossômicos de fita-dupla, com capacidade de se replicarem independente do cromossomo bacteriano. As bactérias possuem a habilidade de transferi-los para outras bactérias da mesma espécie ou não. Em geral os genes contidos nos plasmídios podem estar associados à resistência a antibióticos, produção de toxinas e fatores de aderência (HANES e CHANDLER 1993, ALBERTS e col. 2002, JAYARAM e col. 2004).

Nas últimas décadas, aumentou significativamente o interesse por estudos relacionados a presença de plasmidios em sistemas aquáticos e a 
forma com que ocorre o processo de transferência dessas moléculas entre as bactérias, especialmente aqueles dirigidos a pesquisas de bactérias ambientais resistentes a diversos agentes antimicrobianos (ARANA e col. 1997).

Essa capacidade de transferência horizontal de genes de resistência entre as bactérias tem sido demonstrada também entre aquelas provenientes de tanques de peixes e de sedimentos marinhos (INGLIS e col. 1993, SON e col. 1997, ALBERTS e col. 2002, CHOPRA e col. 2003, JAYARAM e col. 2004, WARREN e col. 2004).

SON e col. (1997) relataram a possibilidade de transferência, por conjugação, de plasmídios associados a resistência entre cepas de $A$. hydrophila e microrganismos potencialmente patogênicos ao homem como no caso de Escherichia coli.

BAUAB e col. (2001) evidenciaram plasmídios em 5 cepas de $A$. hydrophila isoladas de infecçōes intestinais ou extra-intestinais e 2 em cepas de $A$. media isoladas de fezes diarréicas.

RADU e col. (2003) detectaram plasmidios com tamanhos variados em cepas de Aeromonas caviae, A. hydrophila e A. veronii sobria, , isoladas de amostras de peixe da Malásia. 


\section{OBJETIVOS}

\subsection{Objetivo Geral}

- Verificar a qualidade higiênico-sanitária e presença de Aeromonas spp em pesqueiros da Região Metropolitana de São Paulo.

\subsection{Objetivos Especificos}

- Verificar a ocorrência de bactérias indicadoras de contaminação fecal em amostras de água e peixe dos pesqueiros.

- Pesquisar a presença de Salmonella spp, Salmonella enterica subsp. enterica sorotipo Enteritidis e Salmonella enterica subsp. enterica sorotipo Typhimurium em amostras de água dos pesqueiros.

- Pesquisar a ocorrência de Aeromonas spp em amostras de água e peixe dos pesqueiros.

- Conhecer o perfil plasmidial de cepas de Aeromonas spp das amostras de água e peixe dos pesqueiros.

- Discutir a importância do perfil plasmidial de Aeromonas spp.

- Discutir a importância das bactérias indicadoras e patogênicas para a saúde pública. 


\section{MATERIAL E MÉTODOS}

\subsection{Caracterização da Área de Estudo}

Para a execução do presente estudo, 30 pesqueiros do tipo pesque-pague (Figura 1) foram selecionados através de uma amostragem randômica estratificada, a partir de uma lista de empreendimentos da Região Metropolitana de São Paulo (Figura 2), os quais apresentavam-se agrupados em 4 categorias ( $A, B, C$ e D) baseados principalmente na infra-estrutura e prestação de serviços (ESTEVES e col. 2003).

As coletas de campo foram realizadas em duas épocas distintas: de setembro a outubro de 2001, correspondendo ao periodo seco e outra de fevereiro a março de 2002, relativo ao periodo chuvoso. Para cada pesqueiro visitado, foram coletadas uma amostra de água e uma de peixe. 

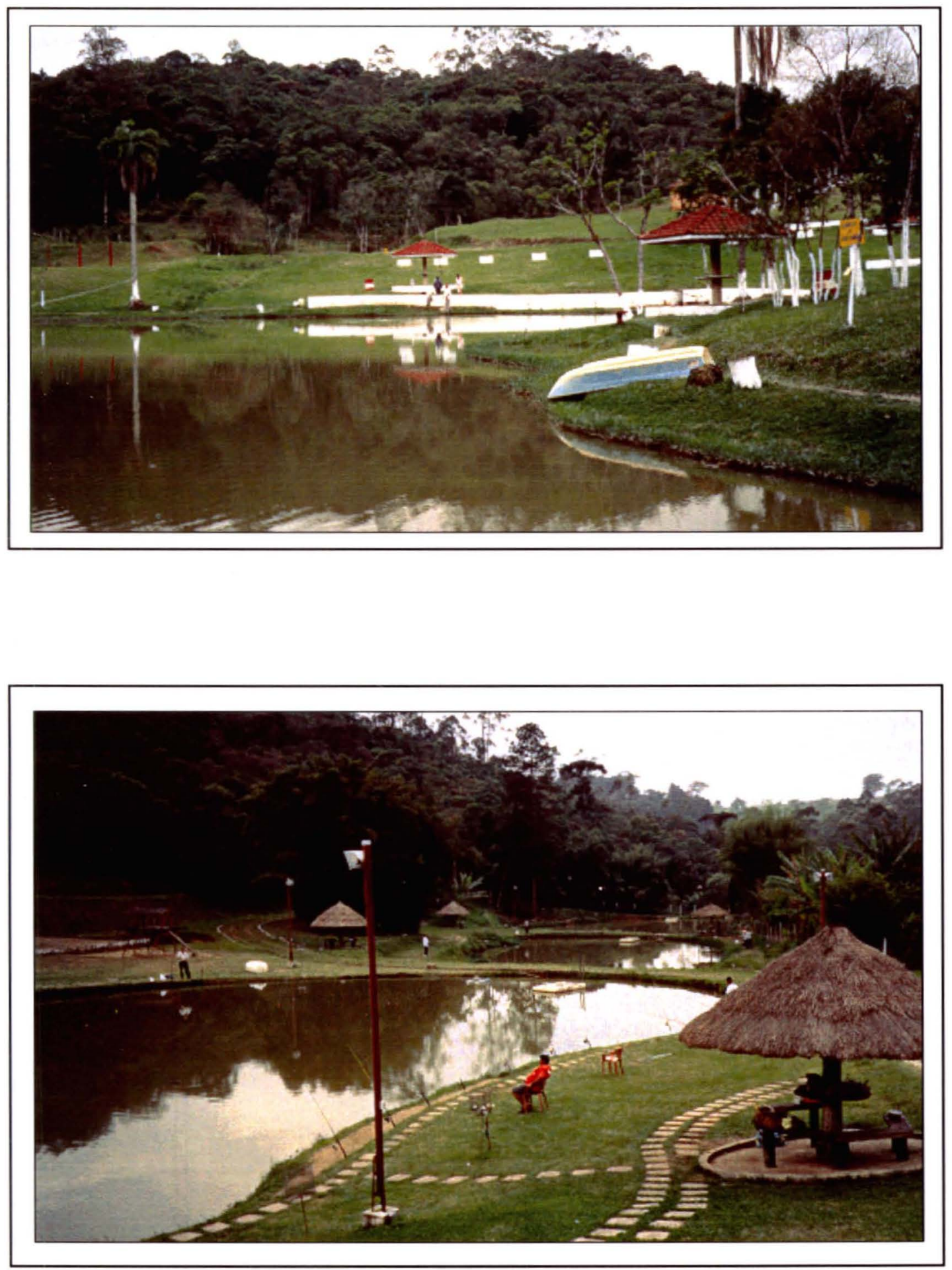

Figura 1: Visão geral de dois estabelecimentos tipo pesque-pague da Região Metropolitana de São Paulo. 


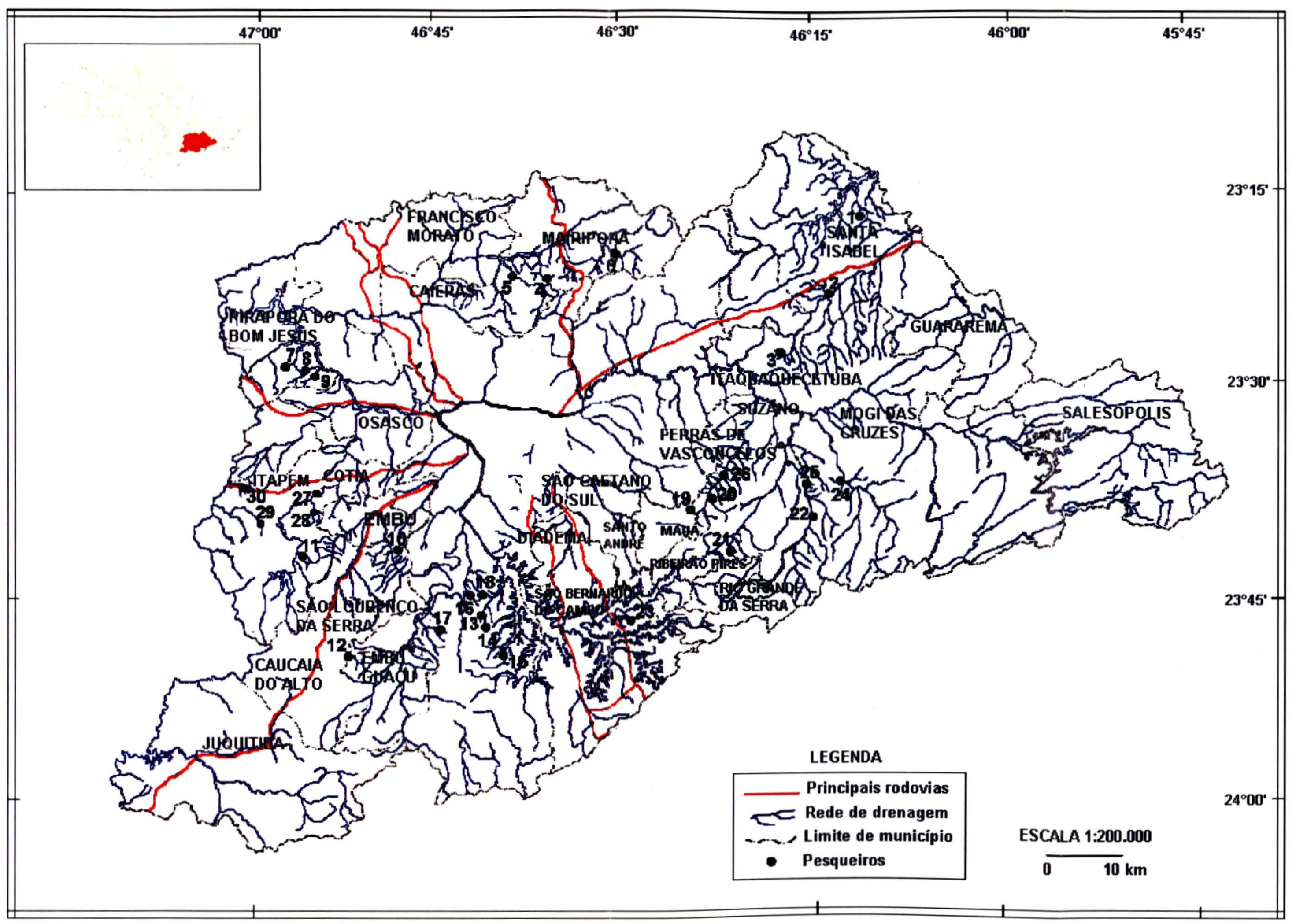

Figura 2: Região Metropolitana de São Paulo com a localização dos pesqueiros estudados (PREZOTTO e CABIANCA) (dados não publicados) 


\subsection{Procedimento de Campo}

Para as amostras de água foram utilizados dois métodos de coleta: um direcionado a pesquisa de bactérias do gênero Salmonella spp e contagem de coliformes fecais, realizado por uma bomba de sucção capaz de bombear a água dos tanques de pesca e outro por uma rede para zooplâncton de malha de $60 \mu \mathrm{m}$, para 10 litros de volume filtrado direcionado a pesquisa do gênero Aeromonas, uma vez que o uso desse equipamento aumenta a chance de isolar essa bactéria (DUMONTET e col. 1996). Quanto às amostras de peixe, foram utilizados anzóis e tarrafas para a coleta.

Após essa etapa, as amostras de água foram armazenadas em frascos plásticos não tóxicos estéreis, e as de peixe, acondicionadas em sacos plásticos estéreis tipo "Zip Lock".

As amostras, conservadas sob refrigeração a uma temperatura de 4 a $10^{\circ} \mathrm{C}$ até o momento da análise, foram encaminhadas ao Laboratório de Saúde Pública da Faculdade de Saúde Pública-USP, onde, no mesmo dia, foram submetidas aos procedimentos microbiológicos. 


\subsection{Contagem de Coliformes Fecais e Presença de Escherichia coli}

A pesquisa foi realizada de acordo com o "Standard Methods For The Examination of Water and Wastewater 19th ed." (APHA 1995). A partir de volumes de $100 \mathrm{~mL}$ das amostras de água coletadas, volumes de $10 \mathrm{~mL}$ da amostra foram submetidos as diluições seriadas em solução salina $0,85 \%$. Em seguida foram submetidos à técnica dos tubos múltiplos para a determinação do Número Mais Provável de organismos do grupo coliformes fecais (NMP) em caldo Lauril Sulfato Triptose (LST). Os tubos de LST que apresentaram formação de gás foram subcultivados em Caldo Escherichia coli $(E C) 24-48$ horas a $42,5^{\circ} \mathrm{C}$. Os tubos de EC que apresentaram crescimento bacteriano e formação de gás foram semeados em placas de Petri contendo meio Eosina Azul de Metileno (EAM) para o isolamento preferencial de cepas de Escherichia coli. As colônias sugestivas isoladas nesse meio foram, posteriormente, confirmadas bioquimicamente em meio IAL de acordo com metodologia descrita por PESSOA e SILVA (1972) (Figura 3).

No Anexo VIII estão disponiveis as formulações dos caldos e meios de cultura utilizados nesse procedimento.

A classificação das águas pertencentes a Classe 2, da Resolução do Conselho Nacional do Meio Ambiente (CONAMA- No 20 de 1/06/1986), foi utilizada como parâmetro microbiológico para contagem de coliformes fecais determinados através do Número Mais Provável (NMP). Esta 
preconiza que água doce destinada à criação natural e/ou intensiva (aqüicultura) de espécies destinadas à alimentação humana, deverá apresentar até 1000 coliformes fecais por 100 mililitros.

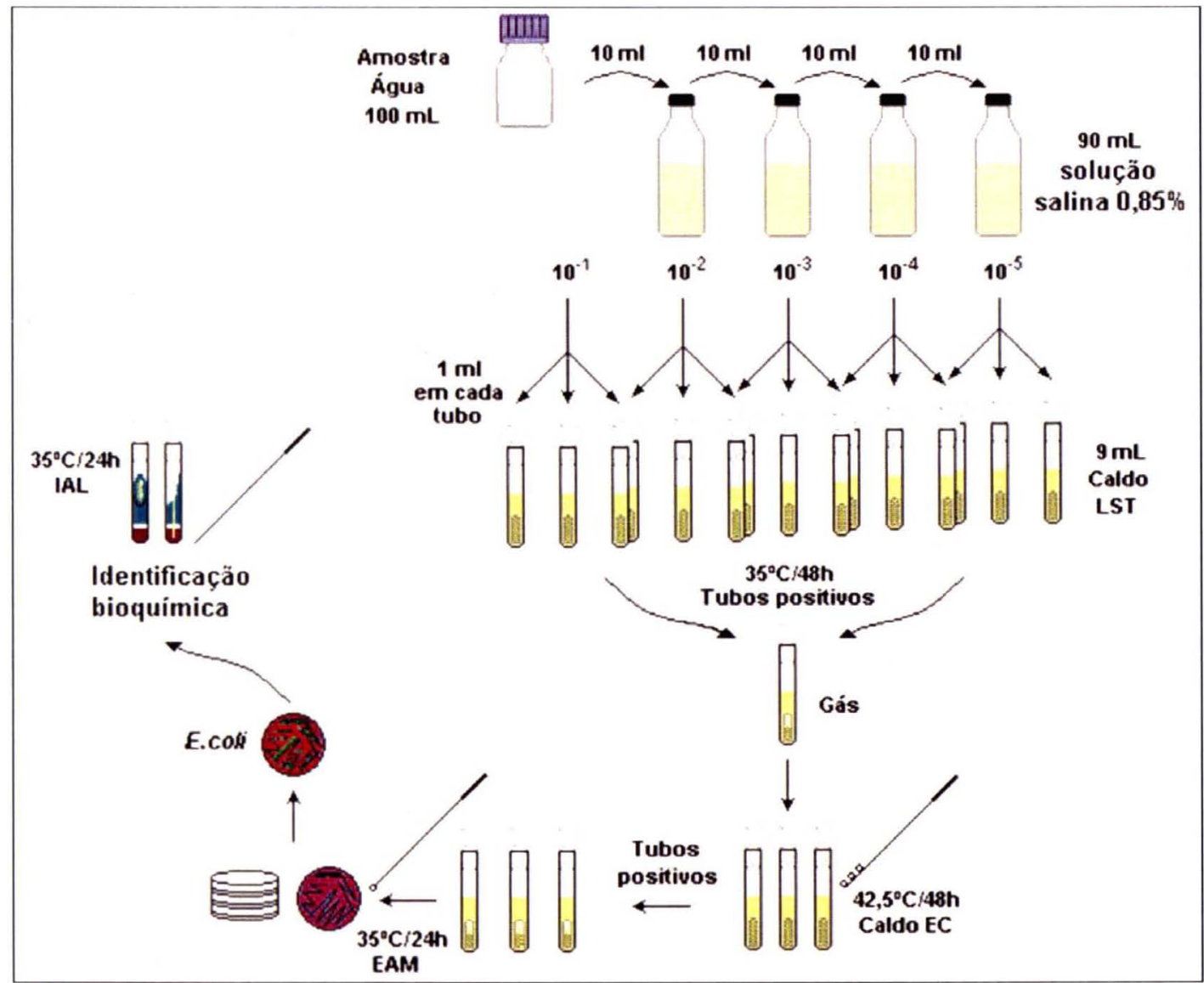

Figura 3: Esquema de análise para contagem de coliformes fecais pelo método do Número Mais Provável (NMP) e teste confirmativo de Escherichia coli. 


\subsection{Ocorrência de Salmonella spp}

\subsubsection{Preparo das Amostras}

Um volume de 1 Litro de água de cada ponto de amostragem foi filtrado através de membranas de éster de celulose (Milipore) com 0,45 $\mu \mathrm{m}$ de porosidade, a partir de um sistema de filtração constituido de bomba de pressão positiva, vasilhame de pressão e porta filtro de aço inoxidável estéril (Milipore). Como pré-enriquecimento, as membranas foram imersas em Caldo Lactosado (AnexoVIII) e incubadas a $35^{\circ} \mathrm{C}$ por 18 horas, segundo metodologia descrita por MARTINS (1979) (Figura 4).

\subsubsection{Enriquecimento das Amostras}

As amostras foram enriquecidas em Caldo Selenito (SC) (AnexoVIII) contendo 0,04g/Litro de Novobiocina (Pessoa e Peixoto, 1971) a $42,5^{\circ} \mathrm{C}$ por $24-120$ horas e em Caldo Rappaport-Vassiliadis (AnexoVIII) incubadas a $35^{\circ} \mathrm{C}$ por $24-48$ horas (VASSILIADIS 1983) (Figura 4).

\subsubsection{Isolamento do Microrganismo}

O isolamento de cepas de Salmonella spp foi realizado através dos meios seletivos diferenciais Salmonella-Shigella (SS), Ágar Xilose Lisina Desoxicolato (XLD) e Ágar Sulfito de Bismuto (BS) (AnexoVIII). As placas foram mantidas a $35^{\circ} \mathrm{C}$ por 24 horas e as colônias típicas das bactérias 
presentes em cada um dos meios foram inoculadas em meio IAL (PESSOA e SILVA, 1972) para a identificação de Salmonella spp (Figura 4).

As cepas que apresentaram positividade pela prova bioquímica em meio IAL, se caracterizando como Salmonella spp, foram submetidas ao teste sorológico para a confirmação do gênero. Para isso, foram utilizados os soros Salmonella polivalente somático e Salmonella polivalente flagelar, da Probac.

Como a determinação do gênero Salmonella não é preconizado pelo CONAMA- No 20 de 1/06/1986 para águas destinadas à aqüicultura, determinou-se como parâmetro biológico, a ausência dessa bactéria nas águas dos pesqueiros tipo pesque-pague, condição recomendado por ALEXANDRINO de PEREZ e CARVALHO FILHO (2003) no Manual de procedimentos higiênicos e sanitários para a criação de peixes saudáveis da Secretaria de Agricultura e Abastecimento do Estado de São Paulo. 


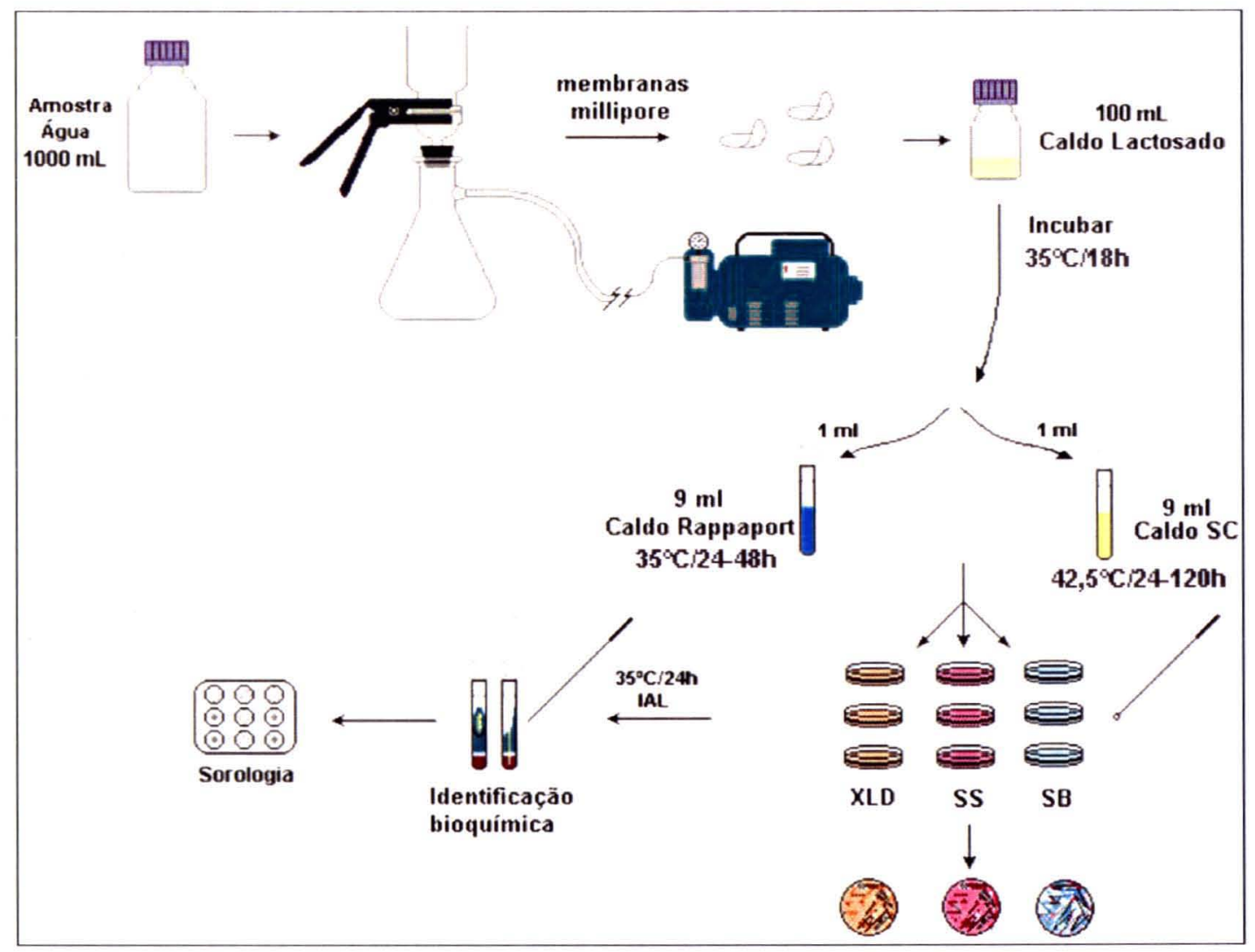

Figura 4: Esquema geral de análise para detecção e confirmação, a partir de provas bioquímicas e sorológicas, do gênero Salmonella em amostras de água.

\subsubsection{Confirmação Molecular}

As cepas do gênero Salmonella spp que foram isoladas no procedimento anterior tiveram seus DNA genômicos extraídos por meio de 3 técnicas distintas: o método do CTAB (Brometo de cetilmetilamônio), do choque térmico segundo Soumet e choque-térmico de acordo com Chapman (MURRAY e THOMPSON, 1980 - descrita por AUSUBEL e col., 1995; SOUMET e col., 1999; CHAPMAN e col., 2001). 
O método do CTAB é uma técnica que garante uma purificação mais intensa do DNA cromossômico, pelas várias etapas que possui de limpeza do material porém, demanda um longo periodo até a finalização de seu processo. Dessa forma, o método que se mostrou mais eficiente foi o de CHAPMAN e col. (2001) por permitir uma boa visualização das bandas de DNA e sobretudo pelo seu rápido tempo de execução.

O procedimento de extração descrito por SOUMET e col. (1999) não foi escolhido, contudo, a seqüência, descrita por esses autores, utilizada na técnica da Reação em Cadeia da Polimerase (PCR) para identificação simultânea do gênero Salmonella e de Salmonella enterica subsp. enterica sorotipo Enteritidis (Salmonella Enteritidis) e Salmonella enterica subsp. enterica sorotipo Typhimurium (Salmonella Typhimurium) (ELZÉBY 1999, YAN e col. 2003), foi mantida; com modificações apenas em dois passos da reação: no passo 4 (anelamento do DNA) de 30 segundos para 1 minuto e no último (extensão final do DNA), de 10 para 7 minutos.

Esta técnica permite a amplificação de moléculas especificas de DNA de cepas bacterianas, de modo a permitir a sua visualização em forma de bandas (pequenas faixas) em gel de agarose.

\subsubsection{Extração de DNA cromossômico de Cepas do Gênero Salmonella Provenientes de Amostras de Água}

As cepas isoladas de Salmonella spp foram semeadas em $10 \mathrm{~mL}$ de Caldo Lúria (AnexoVIII), cultivadas por 18 horas a $35^{\circ} \mathrm{C}$ e centrifugadas a 
$5.000 \mathrm{rpm}$ por 10 minutos a $24^{\circ} \mathrm{C}$. O sobrenadante foi descartado e o sedimento ressuspenso e homogeneizado em $1 \mathrm{~mL}$ de água MilliQ estéril.

O conteúdo foi transferido para um novo tubo tipo "eppendorf" e centrifugado a $12.000 \mathrm{rpm}$ por 3 minutos a $24^{\circ} \mathrm{C}$. O sobrenadante foi descartado e o sedimento ressuspenso e homogeneizado em $200 \mu \mathrm{L}$ de água MilliQ estéril. Os tubos foram selados e incubados a $95^{\circ} \mathrm{C}$ por 10 minutos e depois mantidos $\mathrm{a}-20^{\circ} \mathrm{C}$ por 30 minutos.

Após esse período, foram centrifugados a $12.000 \mathrm{rpm}$ por 10 minutos a $24^{\circ} \mathrm{C}$ e o sobrenadante transferido para um outro tubo, finalizando assim a extração do DNA genômico. Os produtos da extração foram mantidos em geladeira $\left(4^{\circ} \mathrm{C}\right)$ ou em freezer $\left(-20^{\circ} \mathrm{C}\right)$ até o momento do uso.

O esquema dessa extração, pode ser visualizado na Figura 5. 


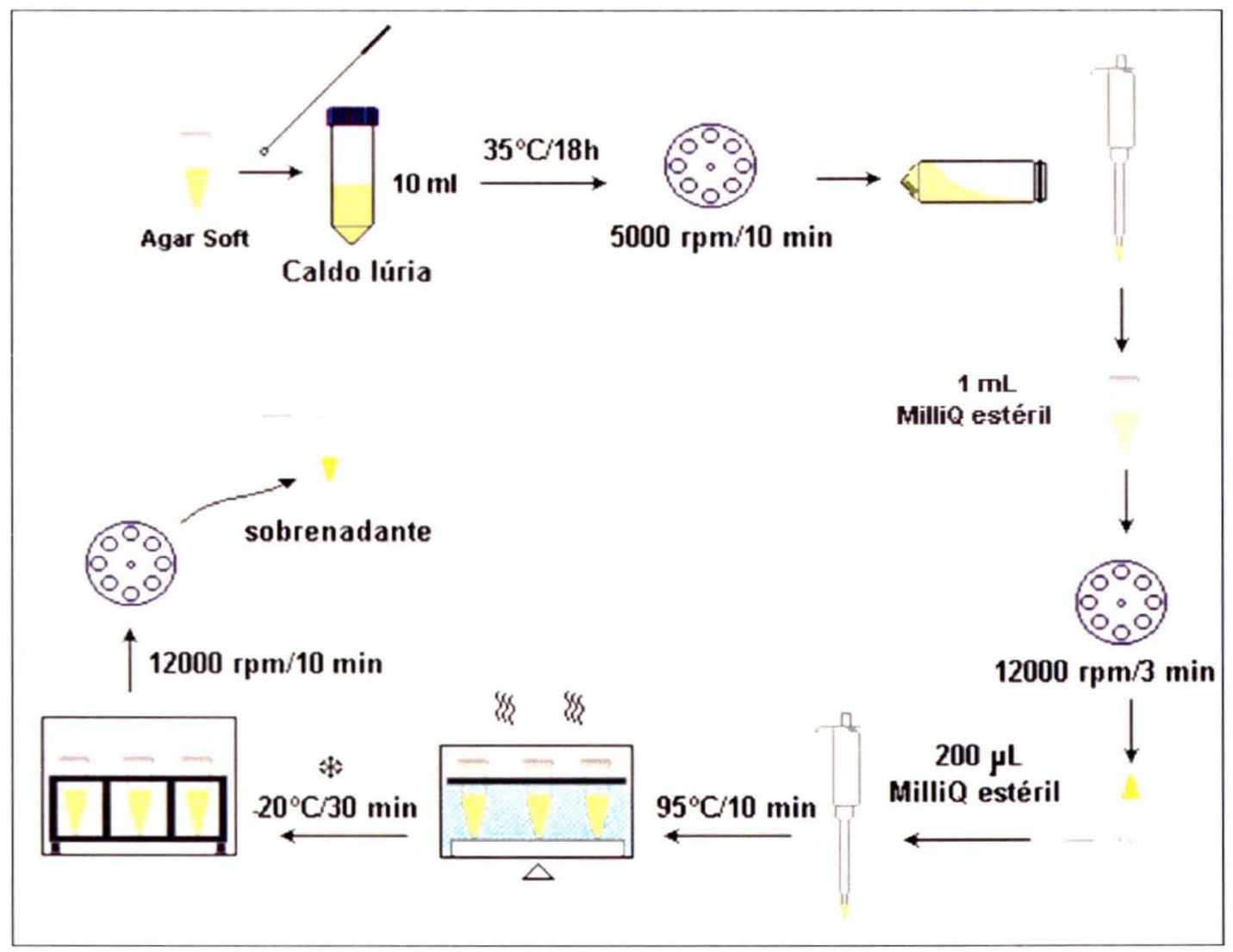

Figura 5: Esquema geral da extração de DNA genômico de cepas de Salmonella spp pelo método do choque-térmico.

\subsubsection{Amplificação do DNA genômico de Salmonella spp a partir da Técnica da Reação em Cadeia da Polimerase (PCR)}

O produto da extração foi submetido à técnica Multiplex PCR para identificação de Salmonella spp, Salmonella Enteritidis e Salmonella Typhimurium descrita por SOUMET e col., 1999 e adaptado pelo Laboratório de Saúde Pública da USP. 
Para a preparação da mistura (master) da Reação em Cadeia da Polimerase foram utilizados os iniciadores (SOUMET e col. 1999) da Invitrogen, conforme segue: ST11-ST15, especifico para o gênero Salmonella spp (ST11: 5'- GCC AAC CAT TGC TAA ATT GGC GCA -3' e ST15: 5'- GGT AGA AAT TCC CAG CGG GTA CTG G - 3' no sentido direto e inverso); S1-S4 especifico para Salmonella Enteritidis (S1: 5'- GCC GTA CAC GAG CTT ATA GA -3' e S4: 5'- ACC TAC AGG GGC ACA ATA AC -3' no sentido direto e inverso); Fli15-Typ04 específico para Salmonella Typhimurium (Fli15: 5'- CGG TGT TGC CCA GGT TGG TAA T -3' e Typ04: 5'- ACT GGT AAA GAT GGC T -3' no sentido direto e inverso).

As concentraçōes padronizadas proporcionais para uma reação de PCR foram: $5 \mu \mathrm{L}$ de amostra de DNA; $0,2 \mu \mathrm{L}$ de taq polimerase

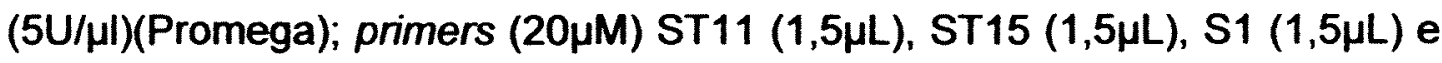

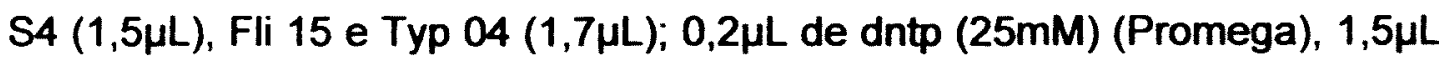
de $\mathrm{MgCl} 25 \mathrm{mM}$ (Promega), 2,5 $\mathrm{L}$ de tampão 10x (Promega) e 6,56 $\mu \mathrm{L}$ de água MilliQ, o que corresponde a um volume final de $25 \mu \mathrm{L}$. Para o cálculo de " $n$ " reações foi utilizada a fórmula:

$\mathrm{C}_{1} \times \mathrm{V}_{1}=\mathrm{C}_{2} \times \mathrm{V}_{2}$,
onde $\mathrm{C}_{1}=$ Concentração Inicial
$\mathrm{V}_{1}=$ Volume Inicial
$\mathrm{C}_{2}=$ Concentração Final
$\mathrm{V}_{2}=$ Volume Final


Após o cálculo das concentrações dos componentes da mistura "master" para a quantidade de reações necessárias, foram transferidos para um tubo de PCR $(0,2 \mathrm{~mL}), 5 \mu \mathrm{L}$ da amostra de DNA e $20 \mu \mathrm{L}$ da mistura.

Para a reação de PCR, os tubos foram dispostos no termociclador (Mastercycler gradient - Eppendorf) programado da seguinte maneira: 1denaturação da fita de DNA a $94^{\circ} \mathrm{C}$ por 5 minutos; 2- realização de 30 ciclos conforme a ordem a saber: 3- desnaturação a $94^{\circ} \mathrm{C}$ por 1 minuto; 4anelamento a $55^{\circ} \mathrm{C}$ por 3 minutos; 5 - extensão a $72^{\circ} \mathrm{C}$ por 1 minuto. Ao término dos 30 ciclos, 6- extensão adicional programada a $72^{\circ} \mathrm{C}$ por 7 minutos, finalizando as reações a uma temperatura constante de $4^{\circ} \mathrm{C}$.

\subsubsection{Visualização de DNA genômico Extraído de Cepas do Gênero Salmonella spp}

O produto da PCR foi então submetido à eletroforese em gel de agarose $1,8 \%$ com intensidade de corrente elétrica de $153 \mathrm{~V}$ por 1 hora e evidenciados com uma solução $0,5 \mu \mathrm{L}$ de Vistra Green (Amersham Pharmacia Biotech). As imagens foram capturadas pelo sistema de aquisição de imagens Epi Chemi II Darkroom (UVP) e o Software Labworks (UVP). Em seguida, a medida dos fragmentos (bandas de DNA) foi comparada com o marcador de peso molecular Ladder $1 \mathrm{~kb}$ (Invitrogen) e determinados pelo Software Gelworks 1D Advanced v. 4.01.

O esquema resumido de todo esse processo encontra-se na Figura 6. 


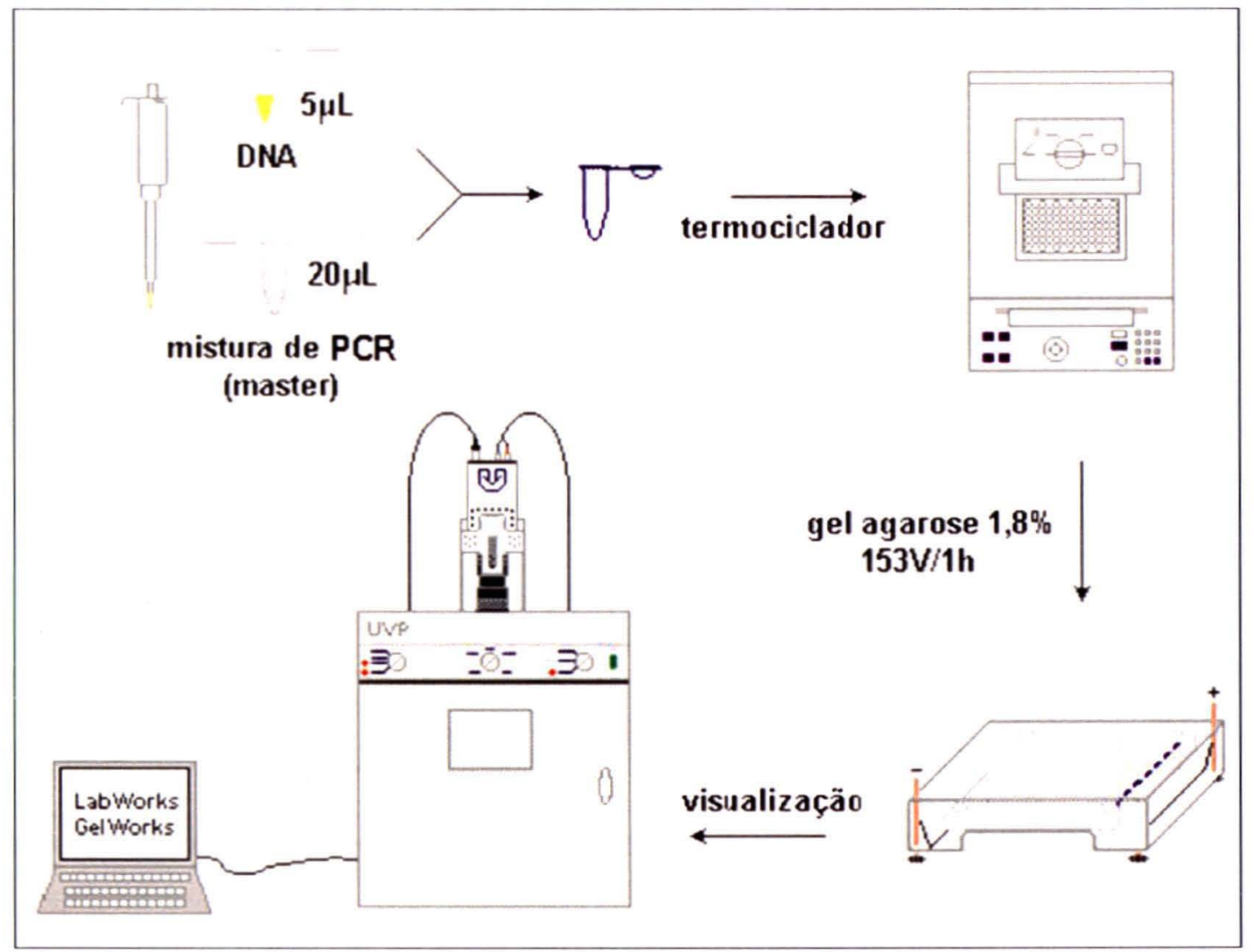

Figura 6: Esquema geral da amplificação e visualização de DNA genômico de cepas do gênero Salmonella pelas técnicas da PCR e eletroforese em gel de agarose. 


\subsection{Ocorrência de Aeromonas spp}

\subsubsection{Enriquecimento das Amostras de Água}

As amostras de água, coletadas com rede de zooplâncton (100 $\mathrm{mL}$ ), foram adicionadas em $100 \mathrm{~mL}$ de Água Peptonada Alcalina (APA) dupla concentração (AnexoVIII), contendo 1\% de cloreto de sódio, pH 8,4 e incubadas por 24 horas a $35^{\circ} \mathrm{C}$. Após esse periodo, cada placa contendo os diferentes meios seletivos foi semeada com uma alçada $(0,3 \mu \mathrm{L})$ do material da superficie do crescimento bacteriano de cada caldo de enriquecimento, para o crescimento do organismo de interesse (Figura 7).

\subsubsection{Enriquecimento das Amostras de Peixe}

As amostras de peixe foram processadas no interior da câmara de fluxo laminar, onde 25 gramas de musculatura cada amostra foram adicionadas a $100 \mathrm{~mL}$ de Água Peptonada Alcalina (APA) (AnexoVIII), contendo $1 \%$ de cloreto de sódio, pH 8,4 e homogeneizadas num liquidificador por aproximadamente 6 segundos. Em seguida foram incubadas por 24 horas a $35^{\circ} \mathrm{C}$. Após esse período, a partir de cada caldo de enriquecimento, foi semeada volumes de $0,3 \mu \mathrm{L}$ do material da superfície do crescimento bacteriano em placas de Petri contendo os diferentes meios seletivos para os organismos em estudo (Figura 7). 


\subsubsection{Isolamento do Microrganismo}

Foram empregados para o isolamento de bactérias do gênero Aeromonas, das amostras de água e peixe, os meios Ágar Sangue Ampicilina contendo $5 \%$ de eritrócitos de carneiro e $10 \mu \mathrm{g} / \mathrm{mL}$ de ampicilina (MATTÉ e col.,1996) bem como o Ágar Amido Ampicilina contendo $10 \mu \mathrm{g} / \mathrm{mL}$ de ampicilina segundo PALUMBO e col. (1985) (AnexoVIII) (Figura 7).

\subsubsection{Isolamento e Identificação das Colônias}

As colônias de Aeromonas spp que apresentaram as caracteristicas descritas para cada um dos meios de isolamento, e ainda teste positivo para a produção da enzima citocromo oxidase (teste de oxidase) foram selecionadas e triadas em meio de Ágar Ferro de Kligler, para a determinação da produção de indol, acidificação da lactose, fermentação da glicose e produção de gás, e então submetidas ao teste de motilidade pela técnica da gota pendente (AnexoVIII) (Figura 7).

Em seguida, os organismos foram submetidos às provas bioquímicas gerais e especificas para cada um dos grupos de organismos a saber: acidificação dos carboidratos - sacarose, manose, manitol, arabinose, inositol, lactose e salicina; crescimento em concentrações de 3, 6, 8 e 10\% de cloreto de sódio e na ausência deste sal; hidrólise da esculina; provas de Voges Proskawer e vermelho de metila; produção de gás a partir da glicose, redução do nitrato, lisina e ornitina descarboxilase e arginina dehidrolase. 
A partir dos resultados obtidos pelas provas bioquímicas os organismos isolados foram identificados por meio da observação da tabela de classificação de espécies do gênero Aeromonas disposto no Quadro 1.

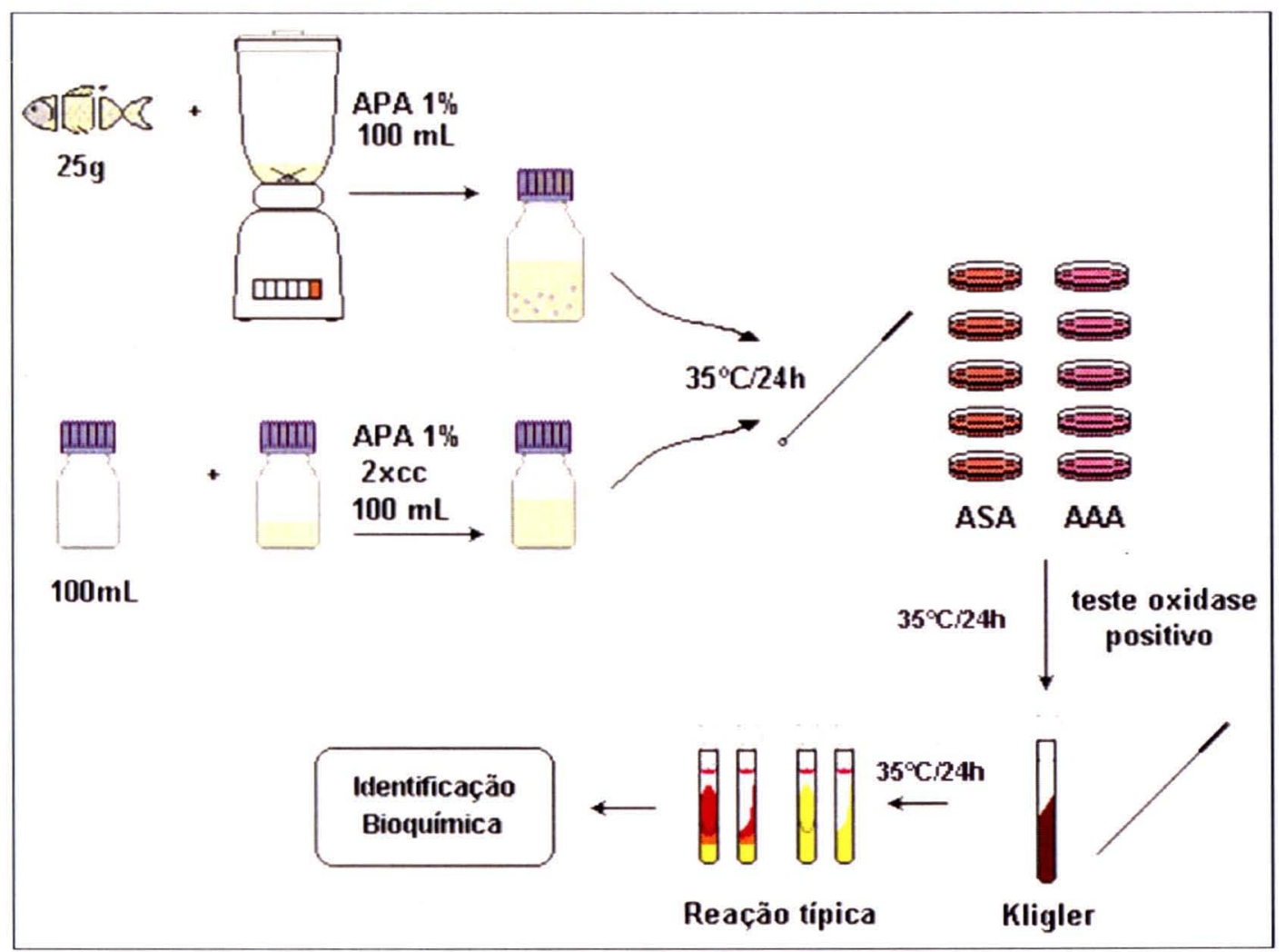

Figura 7: Esquema geral de análise para detecção e identificação de Aeromonas spp, a partir de provas bioquímicas, em amostras de água e peixe. 
Quadro 1. Características bioquímicas para identificação das espécies do gênero Aeromonas.

\begin{tabular}{|c|c|c|c|c|c|c|c|c|c|c|c|}
\hline $\begin{array}{l}\frac{9}{8} \\
\frac{8}{6} \\
\mathbf{w}\end{array}$ & 莡 & $\frac{\text { g }}{5}$ & 害 & $\frac{8}{8}$ & 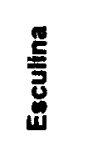 & $\begin{array}{l}\overline{\mathbf{g}} \\
\frac{\mathrm{g}}{\mathrm{I}} \\
\mathrm{x}\end{array}$ & $\frac{\frac{5}{0}}{\overline{0}}$ & $\begin{array}{l}8 \\
\frac{8}{0} \\
\frac{5}{2}\end{array}$ & $\begin{array}{l}8 \\
\frac{8}{8} \\
\frac{8}{8}\end{array}$ & $\begin{array}{l}\overline{\bar{g}} \\
\text { E् }\end{array}$ & $\frac{\text { 들 }}{\frac{\bar{c}}{\mathrm{c}}}$ \\
\hline A. simine & + & + & - & + & V & - & - & - & - & - & + \\
\hline A. hydrophille & + & + & - & + & + & + & + & + & + & + & + \\
\hline 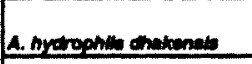 & + & + & - & + & + & + & + & - & NA & + & + \\
\hline A. bostiartum & + & + & - & + & + & \pm & $v+$ & + & $v+$ & + & + \\
\hline A. coviae & + & - & - & + & + & + & + & + & - & + & + \\
\hline A. modia & + & - & - & + & + & + & $v$. & + & - & + & $V+$ \\
\hline A. eucrenophlla & + & - & - & $v+$ & + & + & + & $V+$ & + & + & + \\
\hline A. veronll sobrie & + & + & - & + & - & + & - & V- & + & + & + \\
\hline A. culleicole & + & + & - & + & NA & + & - & - & + & + & + \\
\hline A. veronli veronil & - & + & + & + & + & + & + & - & $V+$ & + & + \\
\hline A. Jenctael & + & + & - & $v+$ & - & + & - & - & + & + & + \\
\hline A. encheleia & + & - & - & $V+$ & + & + & + & - & $V+$ & + & + \\
\hline A. schubertil & + & $V+$ & - & - & - & - & - & - & - & - & + \\
\hline A. trote & + & + & - & V- & - & $V+$ & - & - & $V+$ & + & - \\
\hline A. alloseccharophile & $v+$ & + & $V-$ & + & $V+$ & + & - & $v+$ & + & + & + \\
\hline A. popormi & + & - & - & - & - & + & - & V & + & $V+$ & + \\
\hline A. molluscorum & + & NA & NA & + & + & + & + & + & - & - & + \\
\hline A. salmonicide & $V+$ & V & + & + & $V+$ & + & $V-$ & + & $v+$ & + & $V+$ \\
\hline
\end{tabular}

Fonte: Pidiyar e col., 2002; Abbott e col., 2003; Harf-Monteil e col., 2004; Miñana-Galbis e col. 2004

Nota: $(t)=>85 \%$ de cepas positivas; $(-)=>85 \%$ de cepas negativas; $(V)=50 \% ;(V+)=50$ a $85 \%$ de cepas positivas $(V-)=15$ a $85 \%$ de cepas negativas; $N A=$ não avaliado 


\subsubsection{Extração e Visualização do DNA plasmidial de Cepas do Gênero Aeromonas}

As cepas do gênero Aeromonas que foram isoladas pelos procedimentos microbiológicos tiveram seus DNAs plasmidiais extraídos pelo método descrito por BIRNBOIM e DOLY (1979).

Cada cepa foi semeada em $3,0 \mathrm{~mL}$ de Caldo Lúria, cultivada por 18 horas a $35^{\circ} \mathrm{C}$ e centrifugadas a $5.000 \mathrm{rpm}$ por 10 minutos a $24^{\circ} \mathrm{C}$. O sobrenadante foi desprezado e o sedimento ressuspenso e homogeneizado em $1,0 \mathrm{~mL}$ de salina $0,85 \%$ estéril, o qual foi transferido para um outro tubo tipo "eppendorf". Após este procedimento foi centrifugado a $10.000 \mathrm{rpm}$ por 15 minutos a $24^{\circ} \mathrm{C}$ e o sobrenadante descartado.

Em seguida foram adicionados $100 \mu \mathrm{l}$ de solução I (Anexo iX), o precipitado ressuspenso e incubado em banho de gelo por 30 minutos.

Foram adicionados $200 \mu \mathrm{L}$ de soluçăo II (Anexo IX), homogeneizados por inversão e incubados em banho de gelo por 5 minutos. A seguir foram acrescentados $150 \mu \mathrm{L}$ de solução III (Anexo IX), homogeneizados por inversão e incubados em banho de gelo por 1 hora e 30 minutos.

Após esse período, cada tubo foi centrifugado a $12.000 \mathrm{rpm}$ por 20 minutos a $4^{\circ} \mathrm{C}$. O sobrenadante foi transferido para um outro tubo tipo "eppendorf", no qual foi adicionado $1 \mathrm{~mL}$ de álcool etilico absoluto $99,5 \%$ a $-20^{\circ} \mathrm{C}$. A homogeneização foi realizada por inversão e a incubação por no mínimo 1 hora a $-20^{\circ} \mathrm{C}$ (Figura 8). 


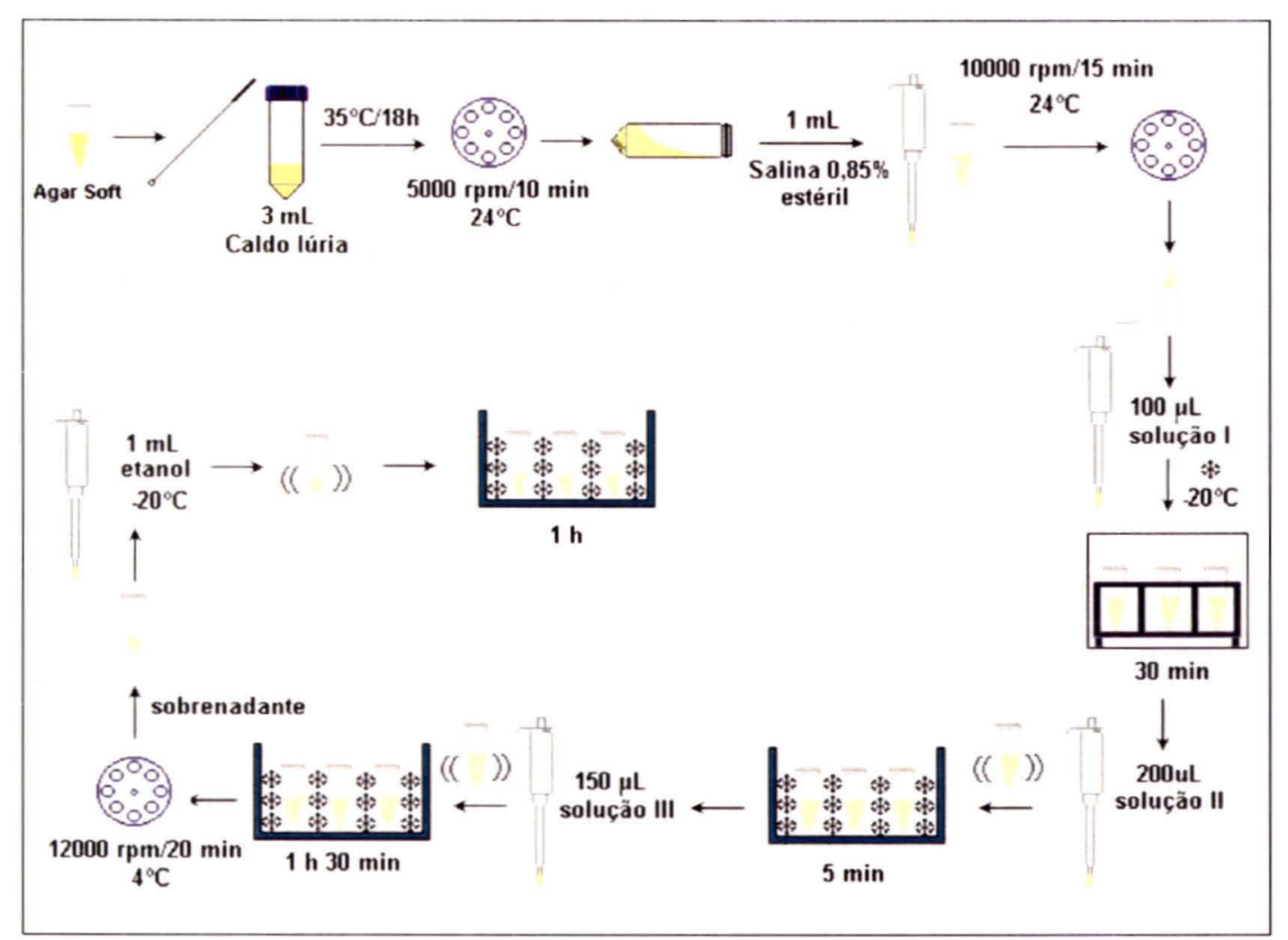

Figura 8: Esquema geral da extração de DNA plasmidial de cepas do gênero Aeromonas

Decorrido o tempo de incubação, cada tubo foi centrifugado a $12.000 \mathrm{rpm}$ por 15 minutos a $4^{\circ} \mathrm{C}$. O sobrenadante foi dispensado com cuidado e o sedimento ressuspenso em $100 \mu \mathrm{L}$ de solução IV (Anexo IX). Em seguida foram adicionados $250 \mu \mathrm{L}$ de álcool etílico absoluto $99,5 \%$ a $20^{\circ} \mathrm{C}$, homogeneizados por inversão e incubados a $-20^{\circ} \mathrm{C}$ por 18 horas.

Após o período de incubação, foram centrifugados a 12.000 rpm por 15 minutos a $4^{\circ} \mathrm{C}$ e o sobrenadante cuidadosamente descartado. $\mathrm{Na}$ seqüência foi lavado com $1 \mathrm{~mL}$ de etanol $70 \%$ a $-20^{\circ} \mathrm{C}$ e centrifugados a $12.000 \mathrm{rpm}$ por 10 minutos a $4^{\circ} \mathrm{C}$. O sobrenadante foi cuidadosamente dispensado e o sedimento colocado para secar sob vácuo por 24 horas. 
O material resultante da extração foi hidratado em $15 \mu \mathrm{L}$ de tampão TEII (Anexo IX) e posteriormente submetido à eletroforese em gel de agarose $1,2 \%$ a uma intensidade de $80 \mathrm{~V}$ por 4 horas. Ao final, o gel de agarose foi corado com brometo de etídio e submetido a uma fonte de luz ultravioleta para detecção das bandas de plasmídios. As imagens foram capturadas pelo sistema de aquisição de imagens Epi Chemi II Darkroom (UVP) e o Software Labworks (UVP). A medida dos fragmentos foi comparada com os marcadores de peso molecular Ladder $1 \mathrm{~kb}$ (Invitrogen) e Hind III (Gibco) e depois determinada pelo Software Gelworks 1D Advanced v. 4.0 (Figura 9).

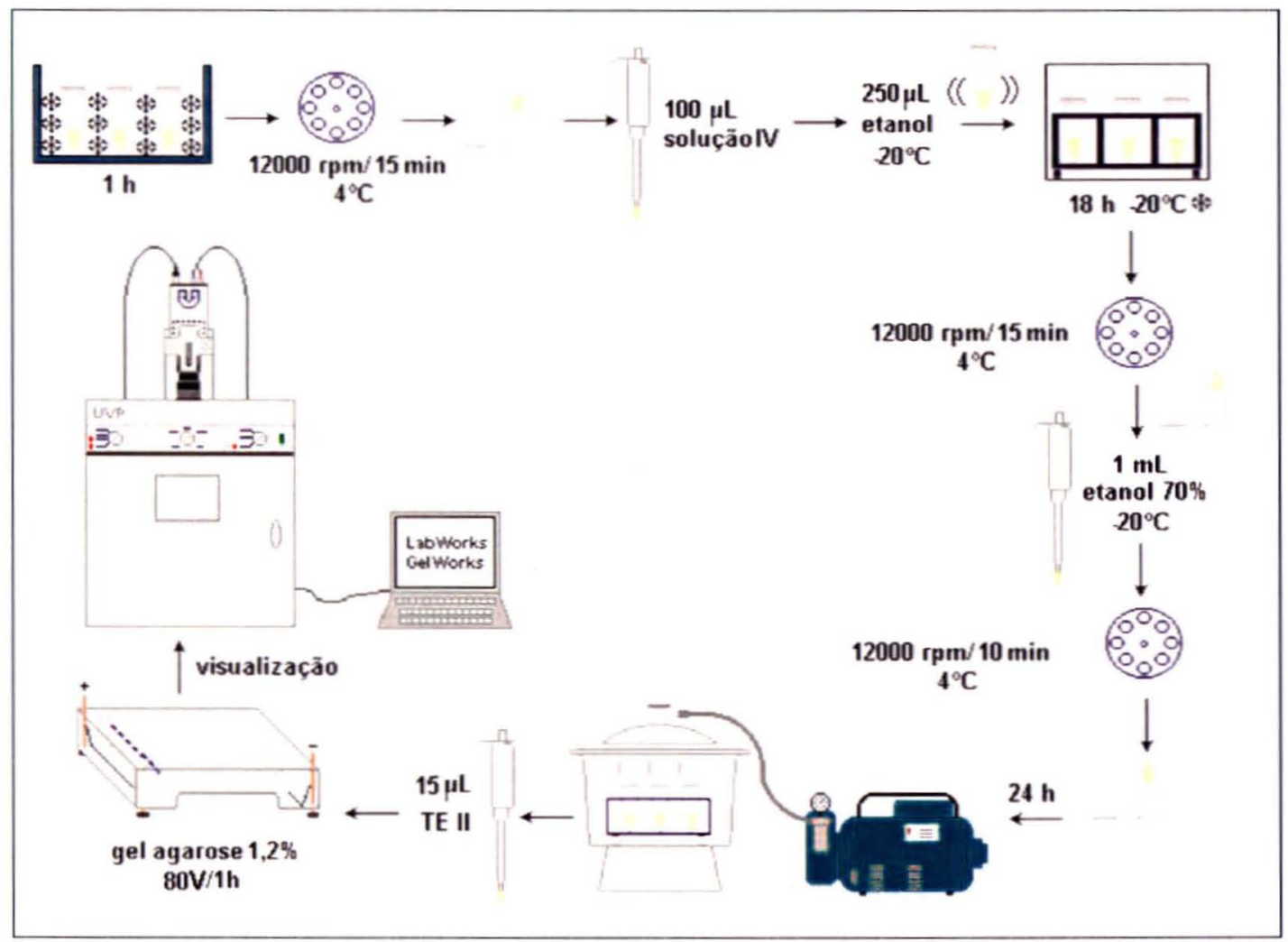

Figura 9: Esquema geral das etapas necessárias para a visualização do DNA plasmidial extraído de cepas do gênero Aeromonas 


\subsubsection{Dados Secundários}

Para relacionar os resultados obtidos com os demais dados obtidos no projeto geral foram utilizados os seguintes dados secundários: potencial hidrogeniônico $(\mathrm{pH})$, temperatura, oxigênio dissolvido, dentre outros foram medidos pela equipe do laboratório de Limnologia do Centro de Estudos de Bacias Hidrográficas do Instituto de Pesca-SP, sob responsabilidade da Dra. Cacilda Thais J. Mercante (MERCANTE e col. 2004, ESTEVES e col. 2003).

Os dados sobre hábito preferencial de tilápias nos pesqueiros analisados, ocorrência de adubação e ração, lançamento de sal grosso, dimilin, sulfato de cobre e formol foram obtidos pela coordenadora geral do projeto Dra. Katharina Eichbaum Esteves do Instituto de Pesca-SP (ESTEVES e col., 2003).

Os resultados referentes aos niveis de contaminação por coliformes fecais e Salmonella spp em amostras de peixe foram analisados por Carlos M. Ishikawa PqC do Instituto de Pesca-SP e Esequiel Liuson (ESTEVES e col. 2003, LIUSON 2003).

Dados sobre o entorno, bacia hidrográfica e presença de microcrustáceos (copépoda) foram disponibilizados pela doutoranda Maria Angela de Abreu Cabianca da Faculdade de Saúde Pública da USP (ESTEVES e col. 2003). 


\subsubsection{Programa Estatístico e Nivel de Significância}

As variáveis numéricas e categóricas obtidas foram submetidas ao teste de correlação de Pearson e Qui-Quadrado $\left(x^{2}\right)$ para a verificação de existência de correlação e associação entre os grupos de organismos pesquisados e ocorrência de alguns produtos quimicos utilizados na água, pelos proprietários. Para isso, foi utilizado o programa estatístico SPSS for Windows v. 8.0 para os quais adotou-se nível de significância $p<0,05$. 


\section{RESULTADOS}

Do total de pesqueiros estudados, foram analisadas $\mathbf{3 0}$ amostras de água quanto à contagem de coliformes fecais e presença de Escherichia coli (E. coli), Salmonella spp e Aeromonas spp, sendo somente esta última igualmente pesquisada nas amostras de peixe.

Além da análise numérica, outras ferramentas também foram exploradas, como a pesquisa estatística e a molecular.

\subsection{Contagem de Coliformes Fecais e Ocorrência de Escherichia coli e Salmonella spp.}

No periodo seco, do total (620) das cepas bacterianas isoladas, foram identificadas 7 (1\%) cepas de Escherichia coli e 13 (2\%) de Salmonella spp.

No período chuvoso, do total (591) das cepas bacterianas, foram isolados, apenas $3(<1 \%)$ cepas de Escherichia coli e $1(<1 \%)$ de Salmonella spp, com predomínio de Aeromonas spp nas duas épocas pesquisadas.

A quantidade de pesqueiros que apresentaram ocorrência das enterobactérias bem como contagem de coliformes fecais, acima do limite preconizado pela legislação CONAMA No $20(01 / 06 / 1986)$ para ambos os períodos, podem ser visualizados na Figura 10. 


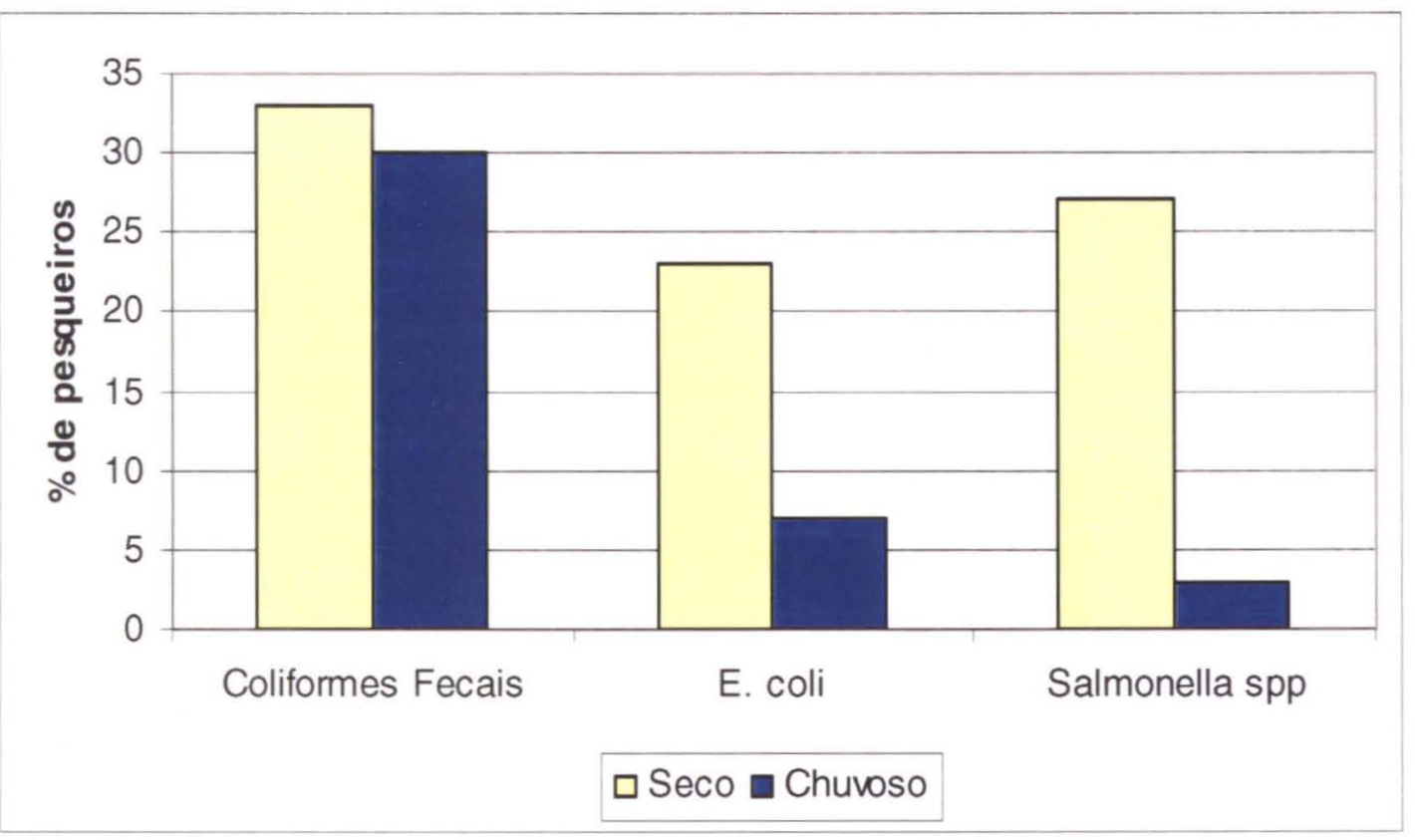

Figura 10: Porcentagem de pesqueiros em desacordo com a legislação CONAMA № $20(01 / 06 / 86)$ para análise de coliformes fecais ( $>10^{3}$ NMP) e presença de E. Coli e Salmonella spp $(n=30)$, set/out2001- fev/mar2002.

Na Figura 11, estão disponíveis as porcentagens de pesqueiros, cujas águas estão em condições microbiológicas inadequadas tanto pelas contagens de coliformes fecais, superiores ao valor permitido pela legislação ambiental, quanto pela presença de cepas de Salmonella spp.

$\mathrm{Na}$ fase seca, pouco mais da metade $(53,3 \%)$ dos estabelecimentos estavam com a qualidade microbiológica de suas águas comprometida para o exercício da atividade, sendo este, resultado superior ao encontrado na fase chuvosa (33,3\%). 


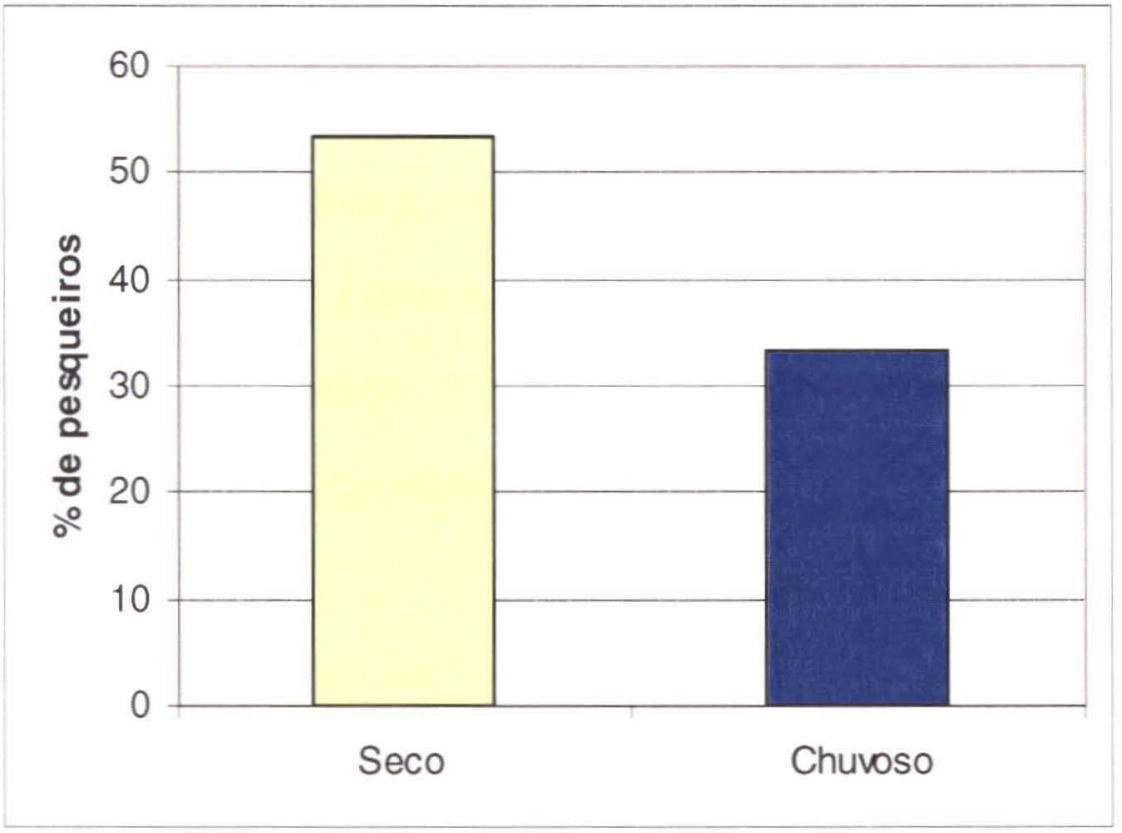

Figura 11: Porcentagem de pesqueiros em desacordo com os limites microbiológicos, segundo contagem de coliformes fecais e presença de Salmonella spp em amostras de água, dos períodos seco e chuvoso $(n=30)$, set/out2001- fev/mar2002.

\subsubsection{Confirmação Molecular de Cepas do Gênero Salmonella}

\subsubsection{Identificação do Gênero Salmonella a partir da Técnica da PCR}

Além da identificação clássica do gênero Salmonella por meio de provas bioquímicas e sorológicas, esse grupo de microrganismo foi submetido a uma etapa confirmatória, através da técnica da Reação em Cadeia da Polimerase (PCR). 
O Quadro 2 permite comparar os resultados obtidos a partir das três provas de identificação para o gênero Salmonella. A utilização dessa técnica molecular possibilitou a confirmação de $14(58 \%)$ cepas em nivel de gênero, de um total de 24 cepas positivas para Salmonella spp, identificada a partir de provas bioquímicas. A pesquisa não demonstrou a presença de Salmonella Enteritidis e Salmonella Typhimurium.

Quadro 2: Comportamento de cepas isoladas de água de pesqueiros, caracterizadas por provas bioquímicas como Salmonella spp, frente a teste sorológico e PCR.

\begin{tabular}{|c|c|c|c|}
\hline \multirow[b]{2}{*}{$\begin{array}{c}N^{\circ} \text { da cepa } \\
\text { de Salmonella spp }\end{array}$} & \multicolumn{3}{|c|}{ Provas } \\
\hline & \begin{tabular}{|c|} 
Bioquímica \\
(IAL)
\end{tabular} & Sorologia & \begin{tabular}{|l} 
Molecular \\
(PCR)
\end{tabular} \\
\hline 1 & $x$ & $x$ & \\
\hline 3 & $x$ & & \\
\hline 5 & $x$ & & \\
\hline 7 & $x$ & & \\
\hline 11 & $x$ & & \\
\hline $19 \mathrm{~A}$ & $x$ & $x$ & $x$ \\
\hline 20 & $x$ & $x$ & $x$ \\
\hline 24 & $x$ & $x$ & $x$ \\
\hline 31 & $x$ & & \\
\hline 32 & $x$ & & \\
\hline 38 & $x$ & & \\
\hline 39 & $x$ & & $x$ \\
\hline 40 & $x$ & & $x$ \\
\hline 41 & $x$ & & \\
\hline 42 & $x$ & $x$ & $x$ \\
\hline 43 & $x$ & $x$ & \\
\hline 45 & $x$ & $x$ & $x$ \\
\hline 67 & $x$ & $x$ & $x$ \\
\hline 69 & $x$ & & $x$ \\
\hline $99 A$ & $x$ & & $x$ \\
\hline 102 & $x$ & & $x$ \\
\hline 105 & $x$ & & $x$ \\
\hline 109 & $\bar{x}$ & & $x$ \\
\hline 148 & $x$ & $x$ & $x$ \\
\hline
\end{tabular}

Nota: $(x)=$ resultado positivo 
Algumas das cepas positivas para o gênero Salmonella, resultantes da aplicação da técnica da PCR podem ser visualizados na Figura 12.

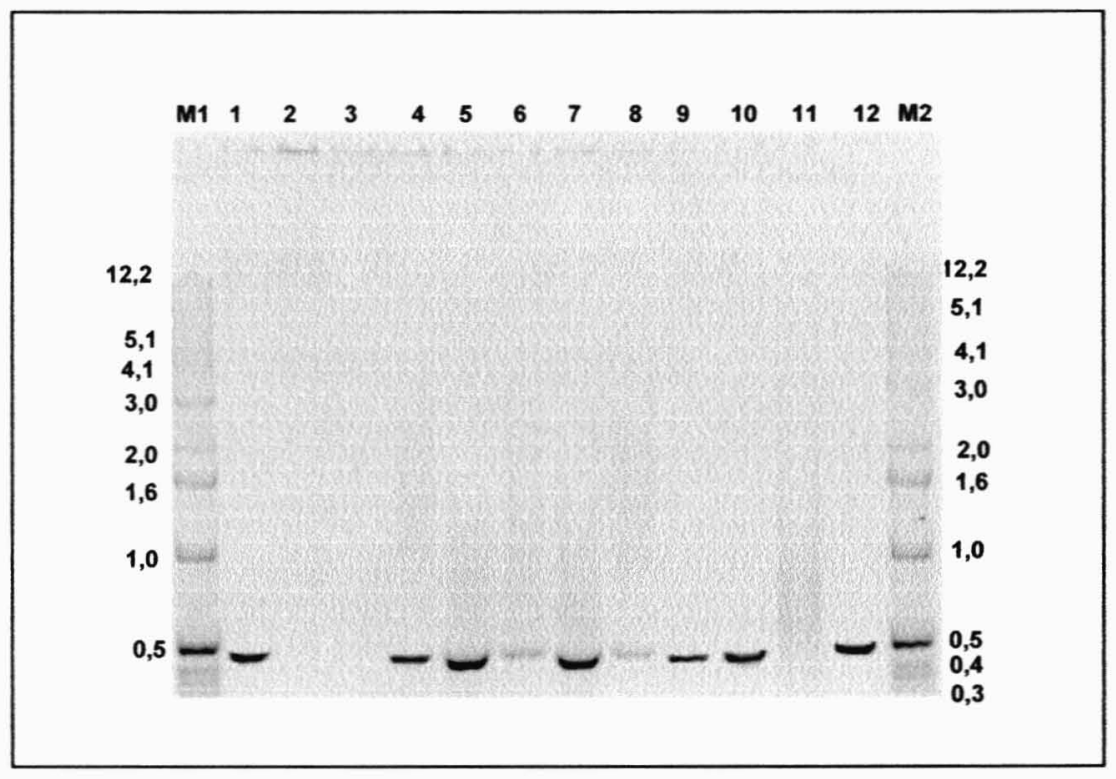

Figura 12: DNA genômico de cepas de Salmonella spp de amostras de água do período seco e chuvoso obtidos pela técnica de PCR. M1 e M2: Ladder $1 \mathrm{~kb}$; linha 1- controle positivo para o gênero Salmonella; linha 2controle negativo; linhas 3, 11- cepas 7 e 31; linhas 4, 5, 6, 7, 8, 9, 10,12cepas $39,67,69,99,105,109,148,40$. 


\subsection{Ocorrência de Aeromonas spp}

Foram isoladas, do total de pesqueiros estudados, $248(40 \%)$ cepas de Aeromonas spp em amostras de água e 352 (58\%) em amostras de peixe, no período seco e no período chuvoso, 219 (37\%) cepas em amostras de água e 370 (63\%) em amostras de peixe.

A quantidade de pesqueiros que apresentou ocorrência de Aeromonas spp está disponível na Figura 13.

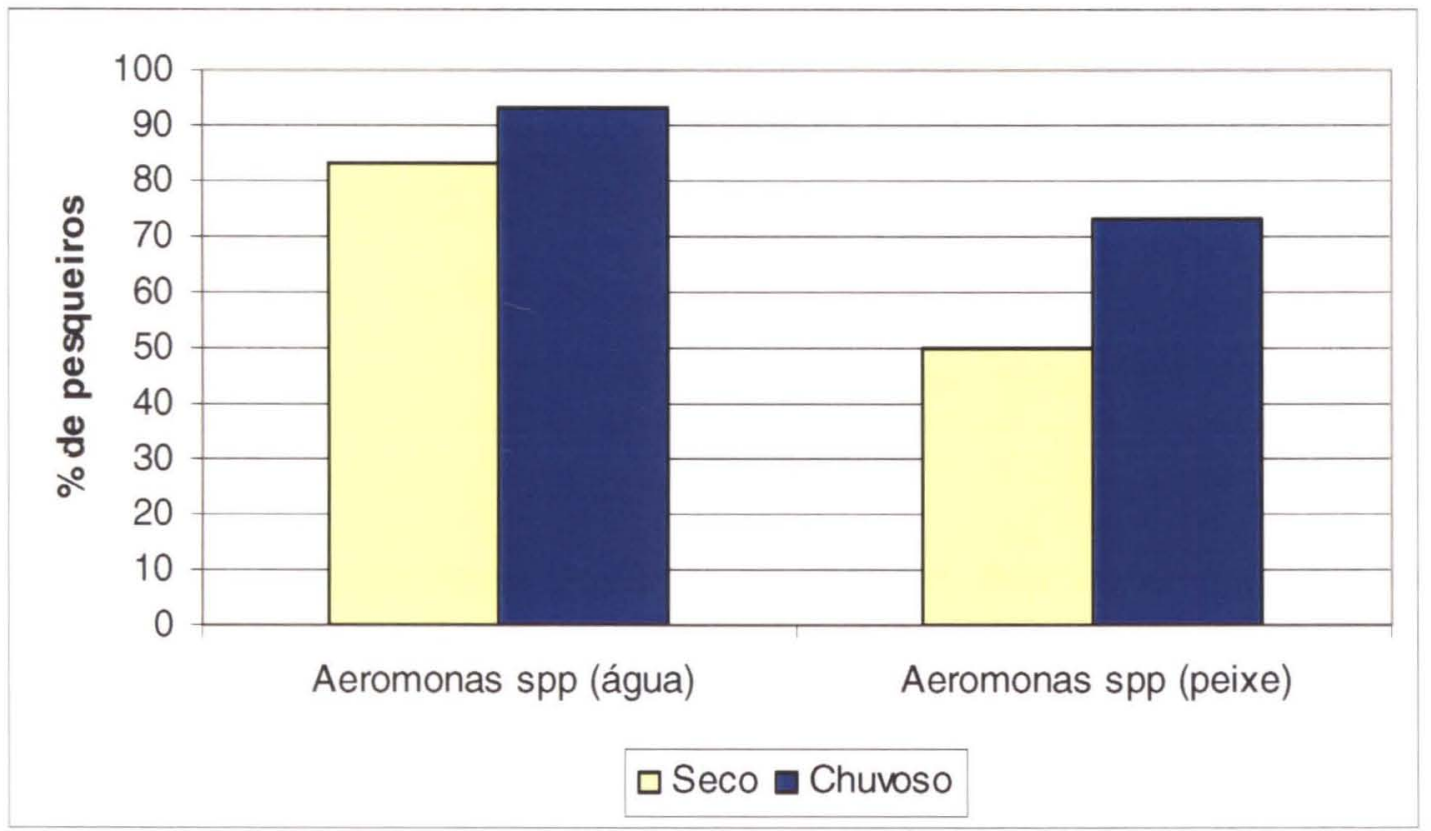

Figura 13: Porcentagem de pesqueiros, nos períodos seco e chuvoso, segundo ocorrência de Aeromonas spp ( $n=30$ ), set/out2001- fev/mar2002. 
Em relação à diversidade de espécies de Aeromonas spp buscouse qualificar e quantificar, o que pode ser observado nas Figuras 14, 15, 16, 17 e 18.

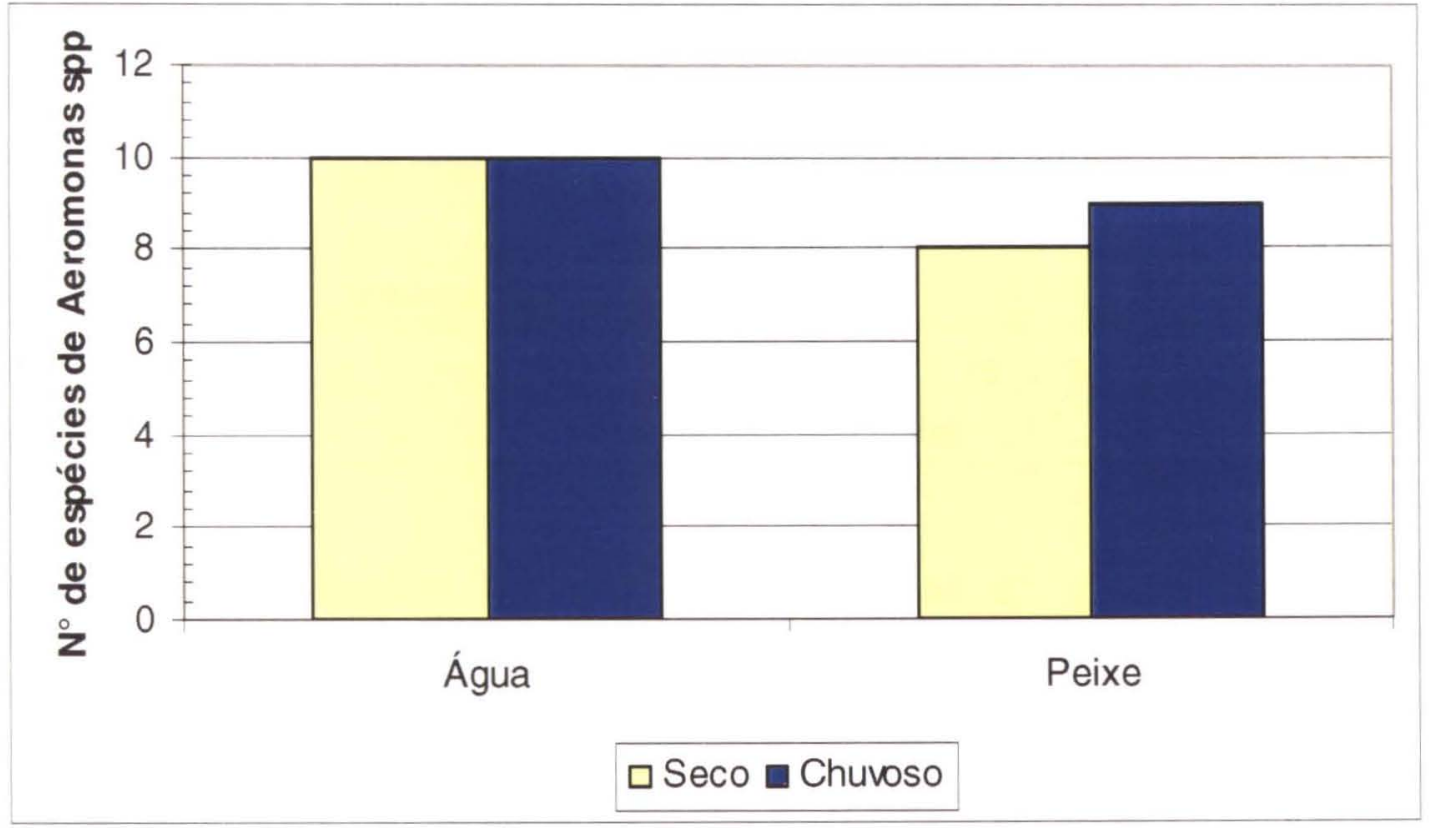

Figura 14: Diversidade de espécies do gênero Aeromonas isoladas de amostras de água e peixe de pesqueiros, no período seco e chuvoso $(n=30)$, set/out2001- fev/mar2002. 


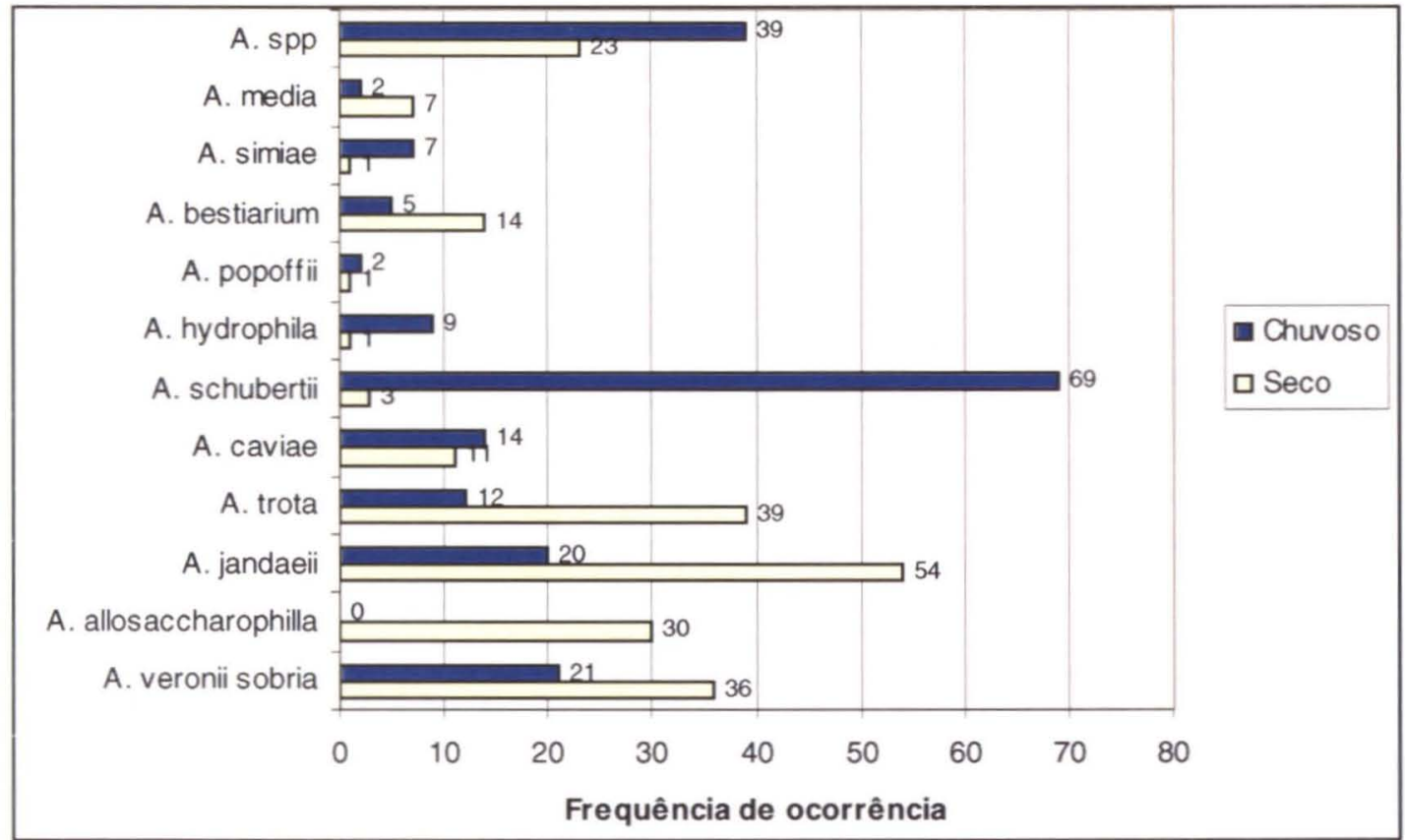

Figura 15: Freqüência de ocorrência de cepas do gênero Aeromonas isoladas das amostras de água dos pesqueiros, no período seco e chuvoso $(n=30)$, set/out2001- fev/mar2002.

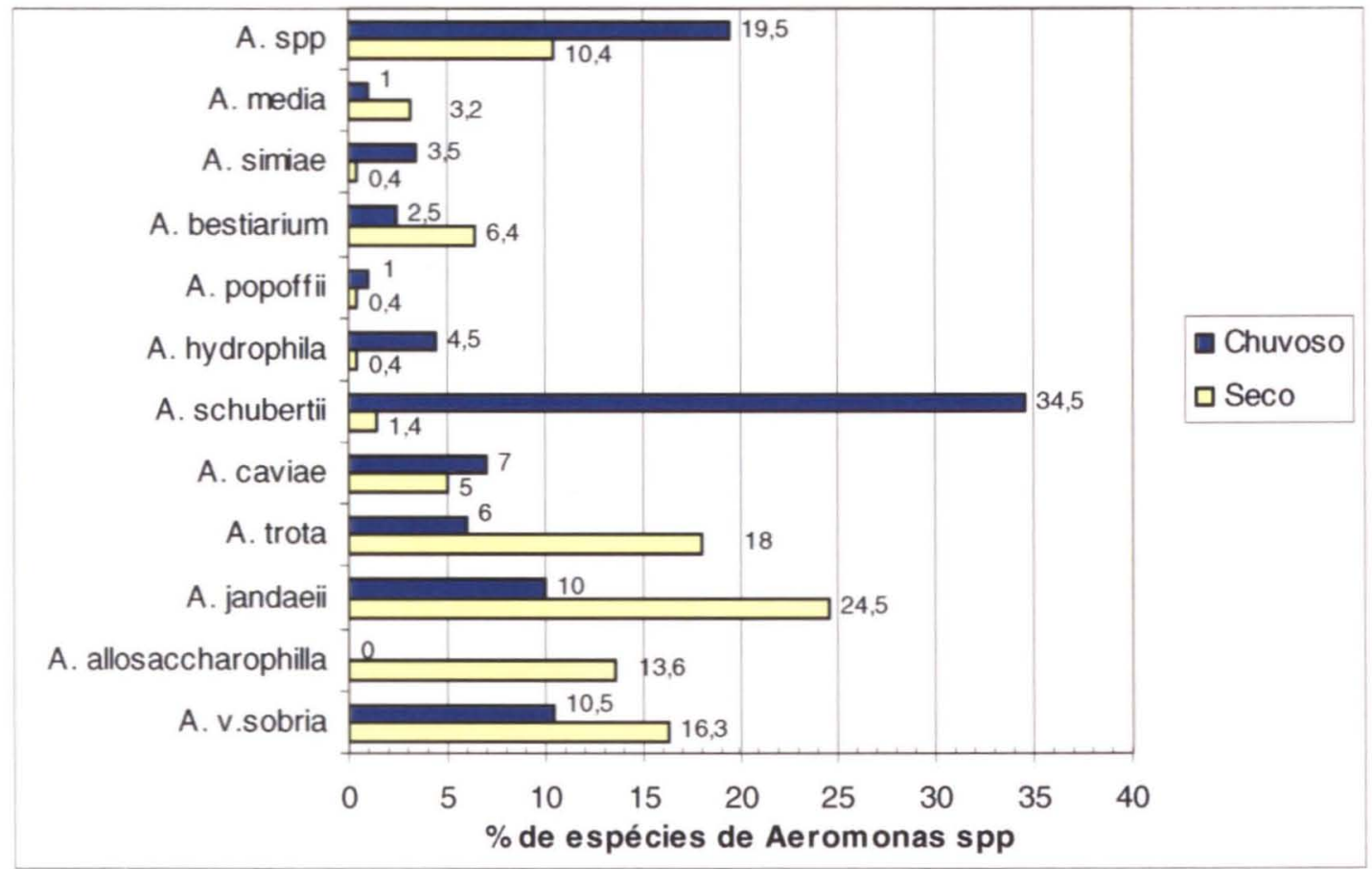

Figura 16: Porcentagem de cepas do gênero Aeromonas isoladas das amostras de água dos pesqueiros, no período seco e chuvoso $(n=30)$, set/out2001- fev/mar2002. 


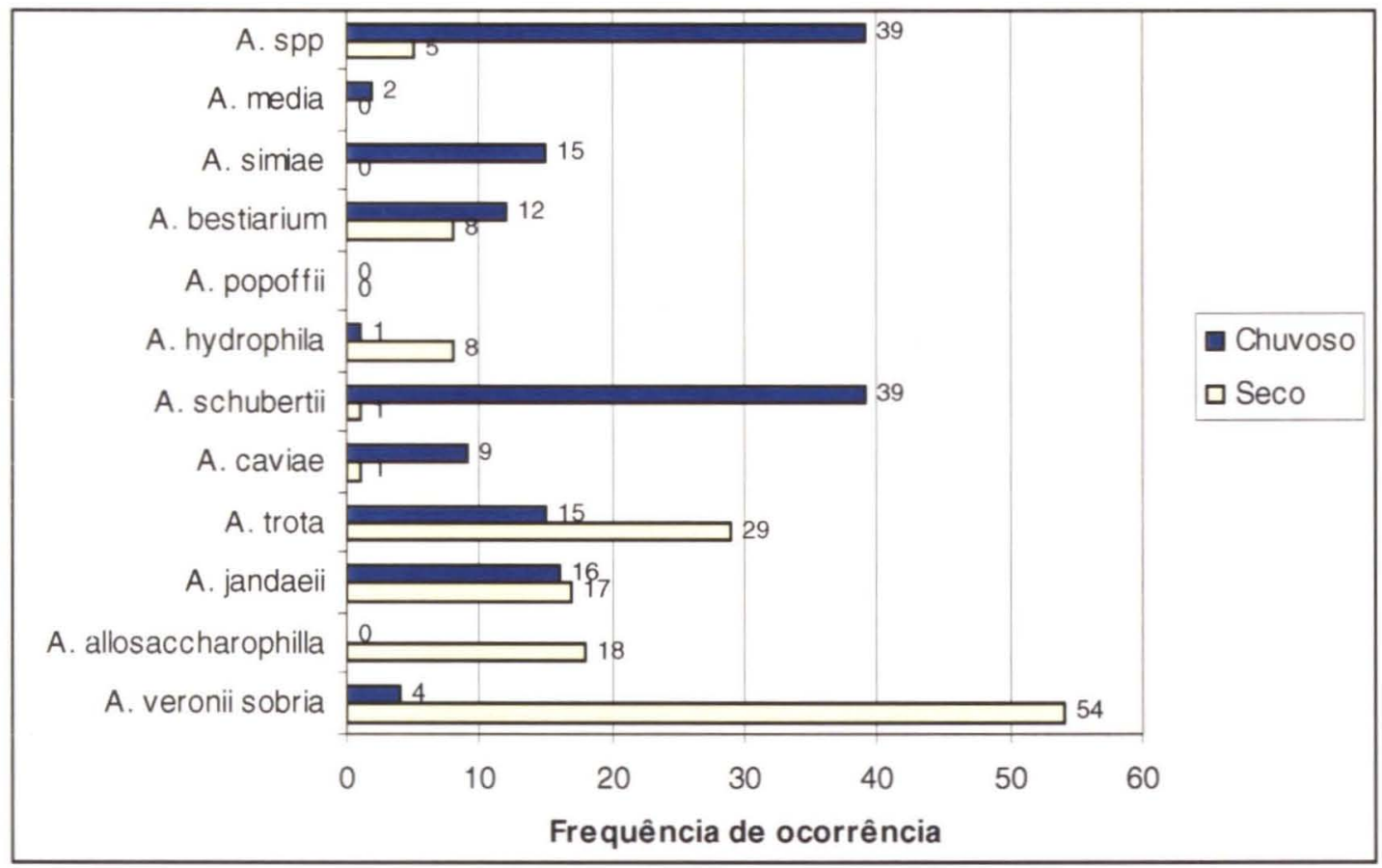

Figura 17: Freqüência de ocorrência de cepas do gênero Aeromonas isoladas das amostras de peixe dos pesqueiros, no período seco e chuvoso $(n=30)$, set/out2001- fev/mar2002.

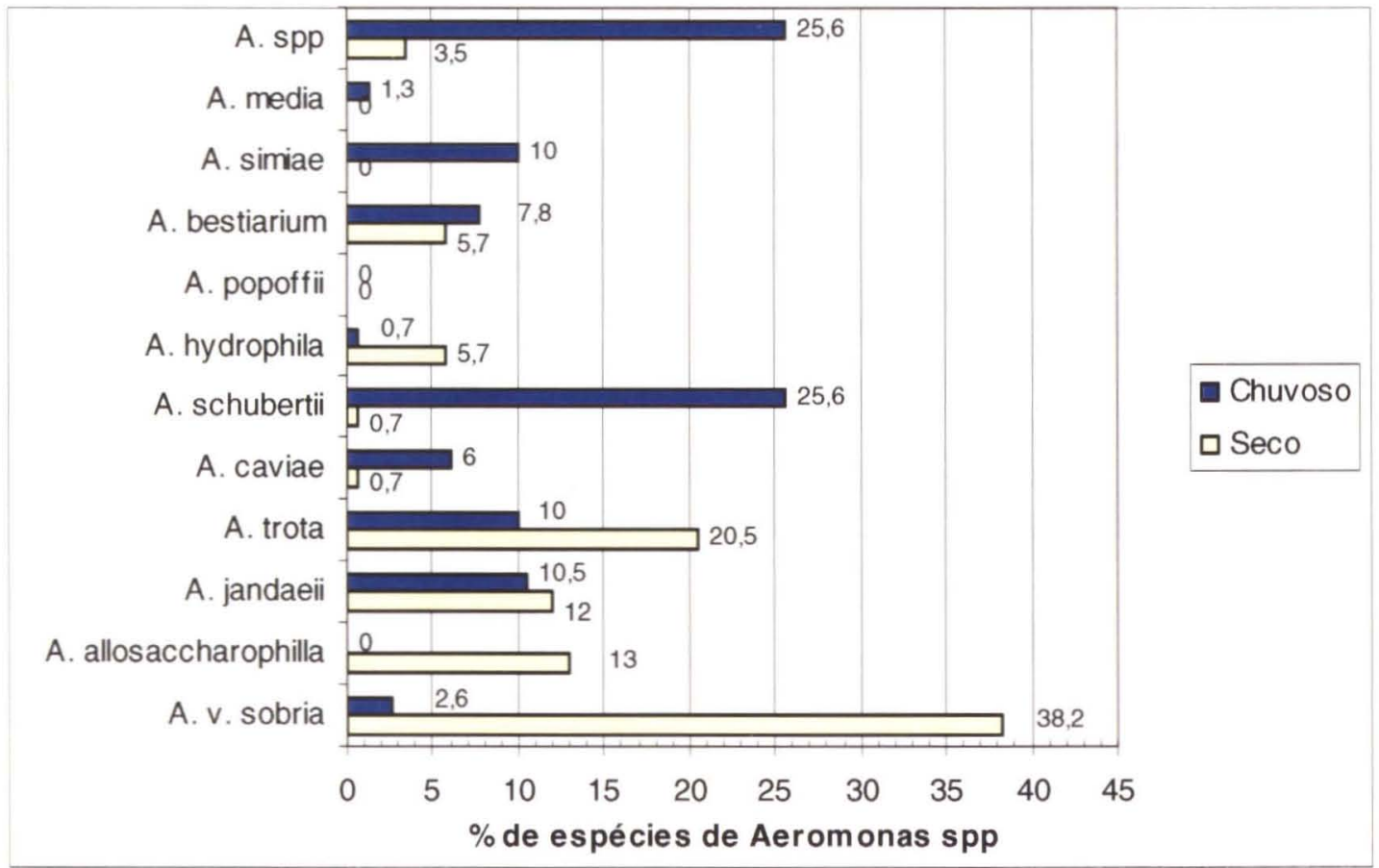

Figura 18: Porcentagem de cepas do gênero Aeromonas isoladas das amostras de peixe dos pesqueiros, no período seco e chuvoso $(n=30)$, set/out2001- fev/mar2002. 


\subsubsection{Ocorrência de DNA Plasmidial em Cepas do Gênero} Aeromonas

Do total (1189) de cepas de Aeromonas spp identificadas através de provas bioquímicas, $515(87 \%)$ foram selecionadas para a extração e estudo do perfil dos DNAs plasmidiais, por compreenderem as espécies patogênicas de maior importância para o homem e outros animais. A porcentagem de cepas de cada espécie que continham pelo menos 1 plasmídio no interior de suas células, em ambas as amostras (água e peixe) e período (seco e chuvoso), foram: A. hydrophila (79\%), A. veronii sobria (73\%), A. jandaei (57\%), A. schubertii (74\%), A. trota (75\%), A. bestiarium (76\%) e A. popoffii (67\%) (Figura 19).

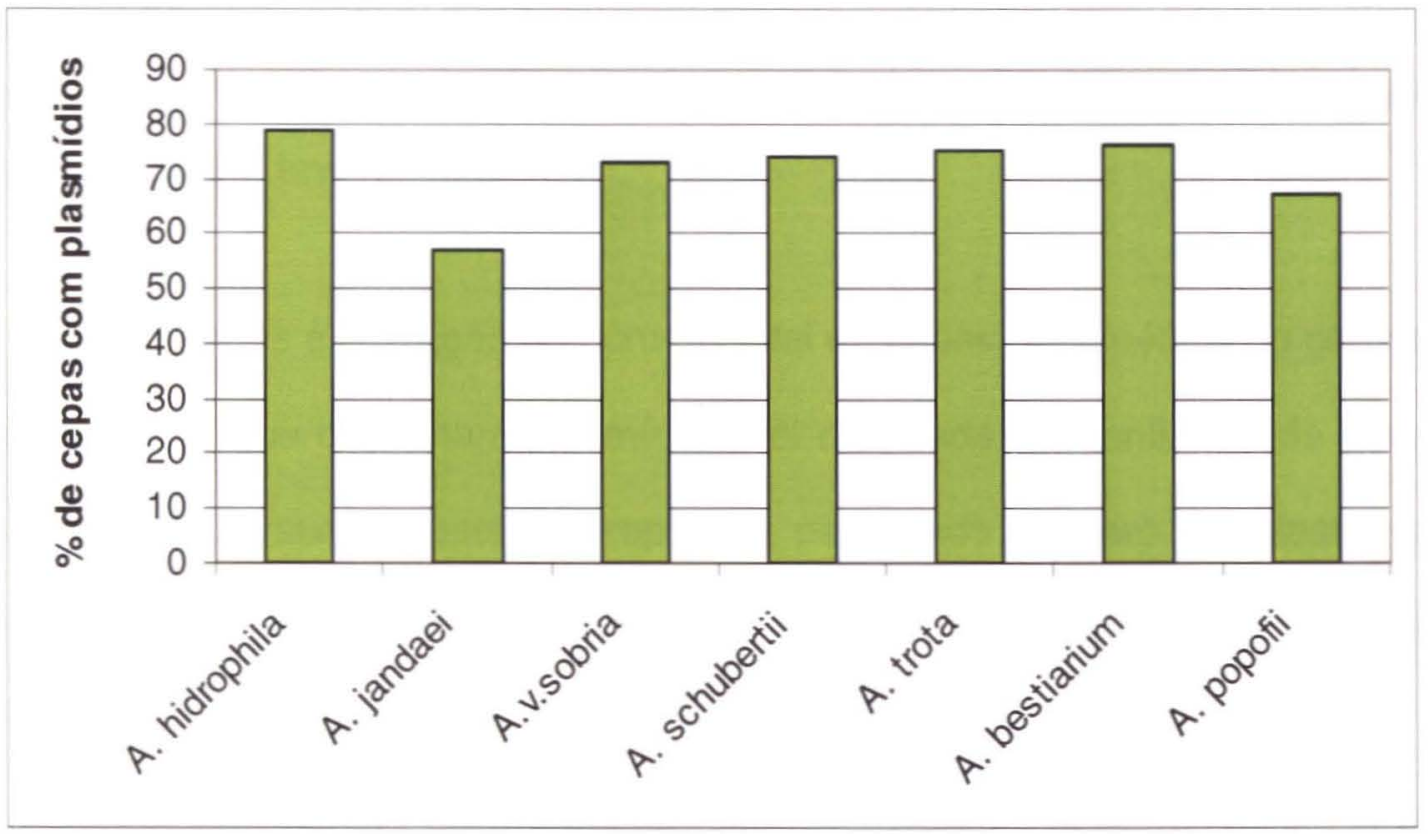

Figura 19: Porcentagem de cepas de espécies do gênero Aeromonas com a presença de plasmídios, isoladas de amostras de água e peixe em ambos os períodos, out/nov2001 - fev/mar2002. 
Na Figura 20 é apresentado a porcentagem de plasmídios, por espécie de Aeromonas spp, por tipo de amostra pesquisada (água/peixe).

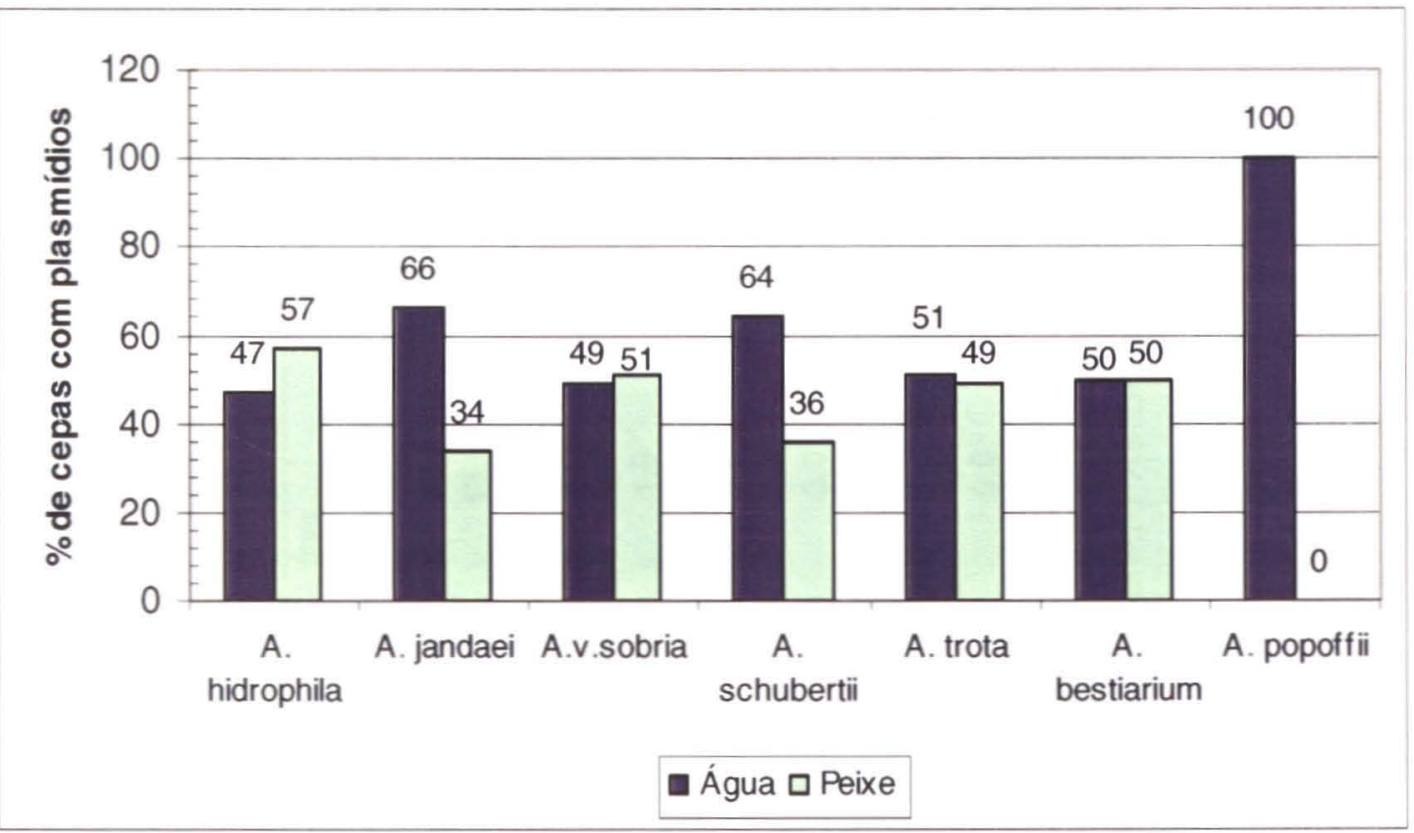

Figura 20: Porcentagem de cepas de espécies do gênero Aeromonas com plasmídios isoladas de amostras de água e peixe de ambos os períodos out/nov2001 - fev/mar2002.

Após a detecção do número total de cepas de espécies do gênero Aeromonas que continham plasmídios, foi calculada a quantidade de cada uma delas e sua respectiva proporção para cada número de plasmídio encontrado, independente da origem da amostra e período o qual pertencia (Tabela 1).

Os pesos moleculares de cada um desses plasmídios, pertencentes a cada espécie de Aeromonas, por origem da amostra e período, também foram averiguados e tabulados como verificado nos Anexos de I a VI. 


\begin{tabular}{|c|c|c|c|c|c|c|c|c|c|c|c|c|c|c|}
\hline \multirow{3}{*}{$\begin{array}{c}\text { N. } \\
\text { plasm }\end{array}$} & \multicolumn{14}{|c|}{ Espécies } \\
\hline & \multicolumn{2}{|c|}{ A. hydrophlla } & \multicolumn{2}{|c|}{ A. jandaei } & \multicolumn{2}{|c|}{ A. v. sobria } & \multicolumn{2}{|c|}{ A. schubertii } & \multicolumn{2}{|c|}{ A. trota } & \multicolumn{2}{|c|}{ A. bestiarlum } & \multicolumn{2}{|c|}{ A. popofii } \\
\hline & $N^{0}$ & $\%$ & $N^{\circ}$ & $\%$ & $\mathrm{~N}^{0}$ & $\%$ & $\mathrm{~N}^{\mathrm{o}}$ & $\%$ & $N^{0}$ & $\%$ & $\mathrm{~N}^{0}$ & $\%$ & $\mathrm{~N}^{0}$ & \\
\hline 0 & 4 & 21,1 & 49 & 43,0 & 31 & 27,0 & 32 & 25,6 & 27 & 24,5 & 7 & 24,1 & 1 & 33,3 \\
\hline 1 & 3 & 15,8 & 20 & 17,5 & 28 & 24,3 & 35 & 28,0 & 29 & 26,4 & 5 & 17,2 & 1 & 33,3 \\
\hline 2 & 5 & 26,3 & 10 & 8,8 & 21 & 18,3 & 11 & 8,8 & 15 & 13,6 & 6 & 20,7 & 0 & 0,0 \\
\hline 3 & 4 & 21,1 & 11 & 9,6 & 9 & 7,8 & 8 & 6,4 & 15 & 13,6 & 6 & 20,7 & 0 & 0,0 \\
\hline 4 & 1 & 5,3 & 8 & 7,0 & 10 & 8,7 & 11 & 8,8 & 9 & 8,2 & 1 & 3,4 & 0 & 0,0 \\
\hline 5 & 0 & 0,0 & 0 & 0,0 & 6 & 5,2 & 7 & 5,6 & 7 & 6,4 & 2 & 6,9 & 0 & 0,0 \\
\hline 6 & 0 & 0,0 & 0 & 0,0 & 4 & 3,5 & 5 & 4,0 & 2 & 1,8 & 2 & 6,9 & 1 & 33,3 \\
\hline 7 & 1 & 5,3 & 4 & 3,5 & 2 & 1,7 & 6 & 4,8 & 3 & 2,7 & 0 & 0,0 & 0 & 0,0 \\
\hline 8 & 1 & 5,3 & 7 & 6,1 & 0 & 0,0 & 10 & 8,0 & 0 & 0,0 & 0 & 0,0 & 0 & 0,0 \\
\hline 9 & 0 & 0,0 & 3 & 2,6 & 0 & 0,0 & 0 & 0,0 & 2 & 1,8 & 0 & 0,0 & 0 & 0,0 \\
\hline 10 & 0 & 0,0 & 1 & 0,9 & 1 & 0,9 & 0 & 0,0 & 0 & 0,0 & 0 & 0,0 & 0 & 0,0 \\
\hline 11 & 0 & 0,0 & 0 & 0,0 & 1 & 0,9 & 0 & 0,0 & 0 & 0,0 & 0 & 0,0 & 0 & 0,0 \\
\hline 12 & 0 & 0,0 & 0 & 0,0 & 1 & 0,9 & 0 & 0,0 & 0 & 0,0 & 0 & 0,0 & 0 & 0,0 \\
\hline 13 & 0 & 0,0 & 1 & 0,9 & 0 & 0,0 & 0 & 0,0 & 1 & 0,9 & 0 & 0,0 & 0 & 0,0 \\
\hline 14 & 0 & 0,0 & 0 & 0,0 & 1 & 0,9 & 0 & 0,0 & 0 & 0,0 & 0 & 0,0 & 0 & 0,0 \\
\hline Total & 19 & 100,0 & 114 & 100,0 & 115 & 100,0 & 125 & 100,0 & 110 & 100,0 & 29 & 100,0 & 3 & 100,0 \\
\hline
\end{tabular}

Tabela 1: Distribuição do número e porcentagem de cepas de espécies do gênero Aeromonas, segundo quantidade de plasmidios detectados. 
Para a visualização das bandas de DNA plasmidial das 515 cepas de Aeromonas spp, estas foram submetidas a eletroforese em gel de agarose $1,2 \%$ por meio de uma cuba de eletroforese horizontal. Em síntese, foi possivel verificar perfis diversificados de DNAs plasmidiais com pesos moleculares, que variaram entre 1,0 a $80 \mathrm{~kb}$, como disposto nas Figuras 21 e 22 . 


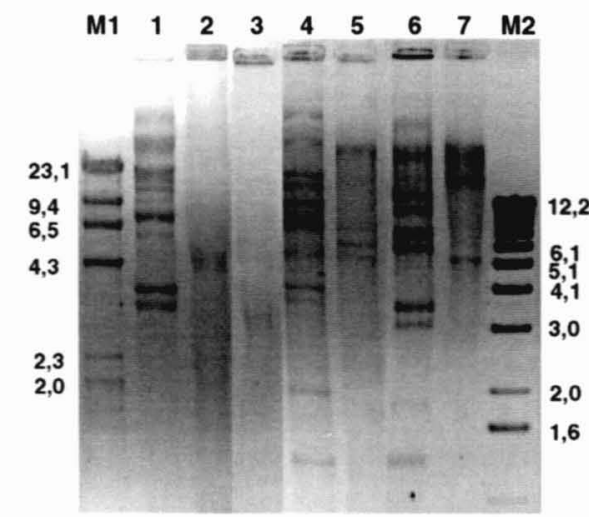

A

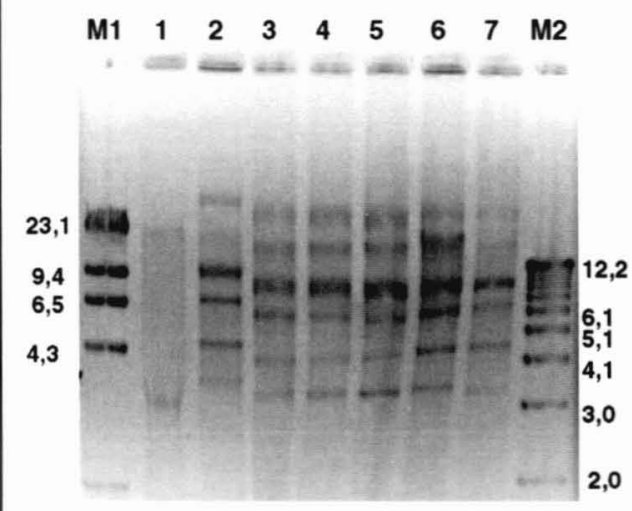

C

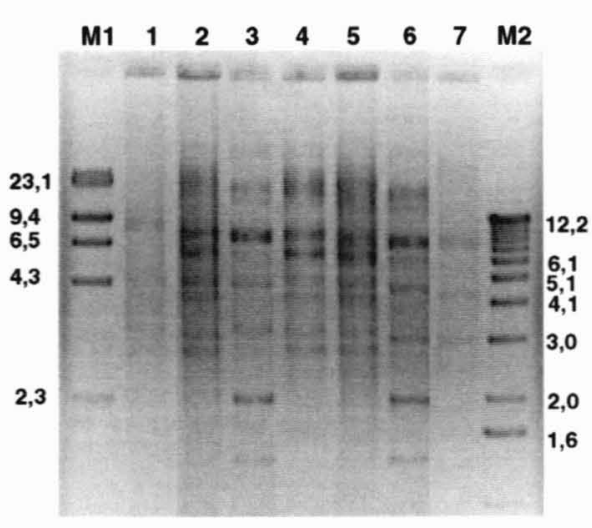

$\mathbf{B}$

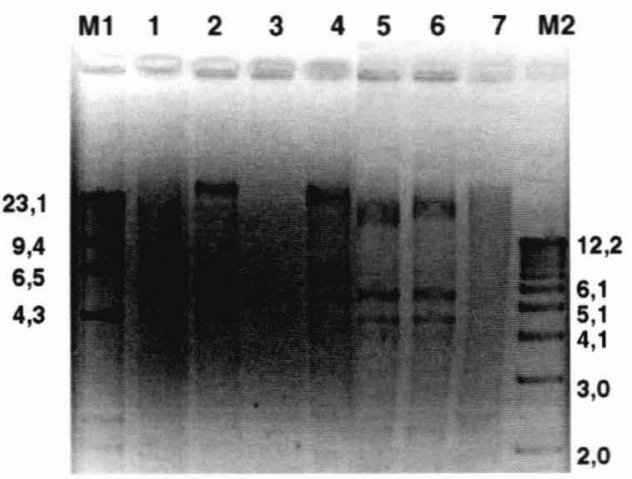

D

Figura 21: Perfil plasmidial de cepas de Aeromonas spp isoladas de amostras de água e peixe dos períodos seco e chuvoso.M1. Hind III e M2: Ladder $1 \mathrm{~kb}$; A: linhas 1, 2, 3, 4, 6 - Aeromonas veroni sobria; linha 5 Aeromonas jandaei; linha 7 - Aeromonas trota; B: linhas 1, 2, 3, 4, 5, 6, 7 Aeromonas jandaei, C: linhas 1, 2, 3, 4, 5, 6, 7 - Aeromonas schubertii; D: Linhas 1, 2, 4, 5, 6 - Aeromonas trota; linha 3 - Aeromonas jandaei; linha 7 - Aeromonas veroni sobria. 


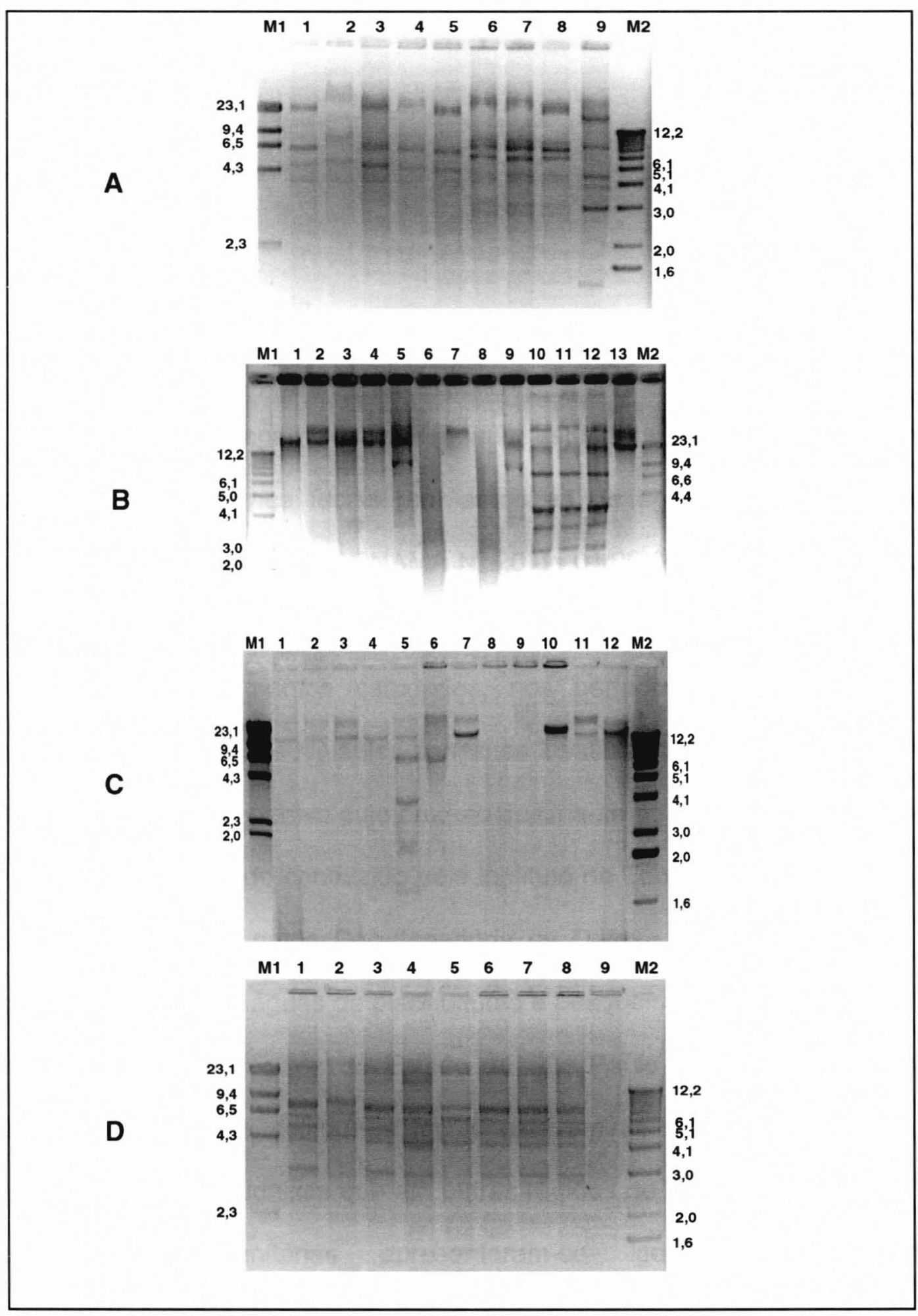

Figura 22: Perfil plasmidial de cepas de Aeromonas spp isoladas de amostras de água e peixe dos períodos seco e chuvoso. M1: Hind III, M2: Ladder 1kb. A:1, 2-Aeromonas trota; 3, 4, 5, 6, 7, 8, 9-Aeromonas jandaei; $\mathrm{B}: 1,2$, 3, 4, 5, 6-Aeromonas hydrophila; 7, 9-Aeromonas bestiarium; 8Aeromonas trota; linhas 10, 11, 12, 13-Aeromonas jandaei; C:1, 2, 3, 4, 5, 8, 11 -Aeromonas bestiarium; 6, 7, 9, 10, 12-Aeromonas hydrophila; D: 1, 2, 3, 4, 5, 6, 7, 8, 9-Aeromonas schubertii. 


\section{DISCUSSÃO}

\subsection{Enterobactérias}

\subsubsection{Coliformes fecais}

A porcentagem de pesqueiros estudados, que apresentaram contagem de coliformes fecais, em amostras de água, acima do limite preconizado pela resolução CONAMA No 20 de 01/06/86 $\left(>10^{3}\right.$ NMP/100mL) está representada na Figura 10 , na qual verifica-se que praticamente $1 / 3$ do total dos estabelecimentos estudados, nos períodos seco e chuvoso, apresentaram condições higiênico-sanitárias insatisfatórios para a prática da atividade da pesca esportiva cujo produto destina-se ao consumo humano.

Outro estudo conduzido pelo Instituto de Tecnologia de Alimentos (ITAL) em parceria com a Coordenadoria de Defesa Agropecuária (CDA) sobre a qualidade de águas de pisciculturas e pesqueiros tipo pesque-pague distribuídos por 40 regiões do Estado de São Paulo, revelou que em 11 delas, os índices de coliformes fecais estavam acima do limite de $10^{3}$ MNP/100mL, o que significa que em outras regiōes do Estado de São Paulo as condições sanitárias apresentaram-se igualmente precárias. (ANONYMUS 2004).

Em outros países, como Itália, Egito, Israel e Estados Unidos, contagens de coliformes fecais acima de $10^{3} \mathrm{MNP} / 100 \mathrm{~mL}$, valor equivalente ao recomendado pela Organização Mundial da Saúde (WHO), também 
foram encontrados em pisciculturas, bem como em lagos e rios onde atividades recreacionais como a pescaria, eram praticadas (WHO 1989, PIANETTI e col. 1998, CRABILL e col. 1999, AN e col. 2002, EL-SHAFAI e col. 2004, HADAS e col 2004).

$\mathrm{Na}$ Figura 10 observa-se ainda uma quantidade relativamente maior de pesqueiros com contagem de coliformes fecais acima de $10^{3} \mathrm{MNP} / 100 \mathrm{~mL}$ em suas águas, na época seca. Esse resultado foi diferente do encontrado na literatura, visto que alguns autores observaram correlação positiva entre elevados níveis de coliformes fecais nos meses mais quentes e chuvosos do ano (MARKOOVÁ e JEEK 1994, PIANETTI e col. 1998, CRABILL e col 1999, PIANETTI e col. 2004).

Este fato pode ser explicado provavelmente pelo comportamento pluviométrico atípico ocorrido em um dos meses de coleta (outubro) correspondente ao período seco do ano de 2001, quando um maior volume pluviométrico foi registrado (Anexo VII).

Nesse sentido, o volume de chuvas pode ter causado um maior aporte de matéria orgânica de origem fecal lançada nas águas dos pesqueiros na época seca, associado também ao movimento das águas provocado pela ação de chuvas e tempestades, responsáveis pela ressuspensão de sedimento carregados de coliformes fecais (AN e col. 2002 e ALM e col. 2003).

Outro fator ambiental que pode ter contribuido para um menor número de coliformes no período chuvoso, corresponde à temperatura média mais elevada das águas registradas nesse período $\left(27,2^{\circ} \mathrm{C}\right)$, quase 
cinco graus a mais que a média calculada no período seco $\left(22,4^{\circ} \mathrm{C}\right)$, já que elevadas temperaturas desfavorecem a sobrevida desses indicadores fecais como constatados por AN e col. (2002), ALM e col. (2003), MENON e col. (2003), NEILL (2004).

MENON e col. (2003) observaram que temperaturas mais elevadas favorecem o desenvolvimento de protozoários que são os principais predadores da comunidade bacteriana, contribuindo, portanto, para o controle da densidade populacional desses organismos, nos meses mais quentes.

Nesse periodo, a densidade da comunidade de algas fotossintetizantes também é favorecida, fator que pode afetar a permanência do grupo fecal no ecossistema aquático, uma vez que o crescimento de algas acarreta numa diminuição nas quantidades de coliformes fecais, como registrado por STEEN e col. (2000).

Associado a ação negativa das algas sobre os coliformes, existe também o fato da radiação solar, no período chuvoso, ser mais intensa do que o período seco, especialmente em países tropicais como o Brasil. De acordo com vários autores, a maior intensidade da radiação solar promove a redução do número de bactérias entéricas, sobretudo do grupo de coliformes (AN e col. 2002, ALM e col. 2003, NEILL 2004). 


\subsubsection{Escherichia coli}

A presença de E. coli em águas de pesqueiros ocorreu, sobretudo, no período seco, conforme observado na Figura 10.

Essa maior ocorrência da E. coli na fase seca, era esperada, uma vez que esta compõe o grupo de coliformes fecais, que ocorreu em maiores contagens $\left(>10^{3} \mathrm{MNP} / 100 \mathrm{~mL}\right)$ neste mesmo período (Figura 10). Nesse sentido, os mesmos fatores ambientais descritos anteriormente para o grupo coliformes também podem ter influenciado a ocorrência de $E$. coli.

Um desses fatores, a ação predatória por parte dos protozoários, foi bem relatada por MENON e col (2003), os quais verificaram uma taxa de mortalidade duas vezes maior das cepas de E.coli em relação às bactérias autóctones do ambiente aquático. Os autores sugerem que essa maior afinidade pelas cepas de E. coli, parece estar relacionada com o seu maior tamanho celular. Observaram também que essa taxa de mortalidade aumentava com a elevação da temperatura das águas.

\subsubsection{Salmonella spp}

O número de pesqueiros que apresentaram cepas de Salmonella spp em suas águas, também foi maior no periodo seco (inverno), assim como descrito para as demais enterobactérias (Figuras 10). Este resultado difere do encontrado por PIANETTI e col. (1998), que verificaram, na Itália, maior ocorrência nos meses de verão. 
Os efeitos dos fatores abióticos, já descritos, sobre o grupo dos coliformes e E. coli podem ser aplicados também ao grupo Salmonella, para o qual, no presente estudo, considerou-se como cepas positivas apenas aquelas confirmadas pela técnica molecular da PCR (Quadro 2 e Figura 12).

O elevado índice pluviométrico ocorrido no mês de outubro (Anexo VII), pode ter favorecido a maior ocorrência de cepas de Salmonella spp no período seco, uma vez que as chuvas são responsáveis pelo maior volume de material orgânico de origem fecal escoado para as águas dos pesqueiros. No presente estudo observou-se a presença de animais de grande e pequeno porte próximos a lagos que estavam a montante das lagoas de pesque-pague (ESTEVES e col. 2003). PIANETTI e col. (1998), também verificaram uma maior freqüência de cepas de Salmonella spp em pontos, ao longo do Rio Foglia (Itália) onde predominavam fazendas com criação de animais de pequeno porte.

Um outro agente que pode estar regulando a população de Salmonella spp no periodo mais quente, é comunidade de protozoários, que como mencionado por MENON e col. (2003), tem uma preferência mais acentuada por essa bactéria, pelo mesmo motivo já exposto para $E$. coli.

Embora esses organismos entéricos dependam de um hospedeiro para sua sobrevivência, têm sua permanência prolongada, graças ao processo de decaimento, pela ação natural da gravidade, na qual encontram um microclima e disponibilidade de nutrientes no sedimento, como será discutido em outro momento (GAUTHIER e ARCHIBALD 2001). 
Com o resultado obtido $(1 / 3)$ de pesqueiros que estavam em desacordo com a legislação para coliformes fecais (Figura 10), os proprietários destes estabelecimentos devem estar mais atentos à ocorrência desses microrganismos potencialmente patogênicos ao homem, nas águas dos pesqueiros, mesmo porque, se também for considerada a presença de cepas de Salmonella spp, a porcentagem de estabelecimentos impróprios para o exercício da atividade de pesca esportiva aumenta para mais da metade $(53,3 \%)$, na época seca e de $33,3 \%$, na chuvosa, como observado na Figura 11.

LIUSON 2003, estudando os mesmos pesqueiros, também verificou que a porcentagem de estabelecimentos que continham peixes impróprios para consumo, quando se baseava na presença de coliformes $(63,3 \%)$, aumentava consideravelmente quando acrescida das amostras de peixe positivas para Salmonella spp (20\%), chegando a $70 \%$.

Diante do exposto, verifica-se que há poucos trabalhos voltados à pesquisa da qualidade microbiológica de águas relacionadas a esse tipo de atividade, de modo que mais pesquisas devem ser estimuladas no sentido de complementar as informações existentes. 


\subsection{Aeromonas spp}

\subsubsection{Ocorrência}

O número de pesqueiros que apresentou cepas de Aeromonas spp em suas amostras de água e peixe foi bastante elevado, tanto na época seca quanto na chuvosa, com um predomínio neste último período, como pode ser observado na Figura 13.

Esses resultados corroboram o estudo conduzido por GAVRIEL $e$ col.(1998), os quais sugeriram a existência de uma relação entre altas densidades de cepas de Aeromonas spp isoladas de reservatórios e períodos de maior precipitação pluviométrico.

PIANETTI e col., em 1998 e 2004 também puderam observar, no período seco, uma grande ocorrência do grupo Aeromonas que pode ter sido favorecida pela menor intensidade dos raios solares associado à menor ocorrência de algas fotossintetizantes (BENCHOKROUN e col. 2003).

Em face dessas informações verifica-se que essa bactéria é bastante adaptada a diversas influências ambientais, exatamente por se tratar de um organismo autóctone do ecossistema aquático e independente de um hospedeiro para sua sobrevivência.

A presença de coliformes fecais nas águas dos pesqueiros também poderiam estar desfavorecendo as cepas de Aeromonas spp; entretanto essa relação ainda é bastante controversa, pois nem todos os 
pesquisadores verificaram o mesmo resultado (PIANETTI e col. 2004). No presente estudo essa correlação também não foi significativa $(p>0,05)$.

Outras correlações e associações entre Aeromonas spp e E. coli e Aeromonas spp e Salmonella spp pesquisadas no presente estudo também não foram estatisticamente significativas. $O$ mesmo foi observado por PIANETTI e col (1998) e ROCHA (2004).

Outra relação descrita na literatura corresponde a associação entre a ocorrência de espécies do gênero Aeromonas spp e populações de copépoda (DUMONTET e col. 1996), entretanto, no presente estudo, essa correlação não foi estatisticamente significativa $(p>0,05)$.

O elevado número de cepas de Aeromonas spp encontrado nas águas dos pesqueiros também se refletiu nas amostras de peixes, tanto no período seco (352) quanto no chuvoso (370).

Esse resultado pode ser visualizado na Figura 13 entre os estabelecimentos analisados, na qual se observa um elevado número de pesqueiros cujos peixes apresentavam-se contaminados por Aeromonas spp. Em metade dos estabelecimentos esse gênero foi registrado nos peixes, sendo este valor mais alto nos meses de maior precipitação pluviométrica (verão), chegando a pouco mais de $70 \%$ do total dos pesqueiros analisados.

Vários autores também reportaram isolados de Aeromonas spp em várias partes do corpo de peixes, inclusive de tilápias, como será descrito no próximo item (OGBONDEMINU e OKOYE 1992, EASA e col. 1995, KHALIL e HUSSEIN 1997, RALL e col. 1998, GONZÁLEZ e col. 2001, 
VIVEKANANDHAN e col. 2003 e HATHA e col. 2004, AL-HARBI e UDDIN 2004).

Esse resultado foi influenciado pela grande quantidade de cepas de Aeromonas spp nas águas dos pesqueiros. São bactérias autóctones do ambiente aquático e portanto, a sua presença pode ser sempre esperada, mas a sua contaminação nos peixes pode ser controlada mais facilmente se estes forem mantidos em águas dentro dos padrões, não apenas microbiológicos, mas também físico-químicos, além de baixa densidade populacional, uma vez que esses fatores atingem diretamente o sistema imunológico dos peixes e que caso não sejam observados, os tornam os animais enfraquecidos e sujeitos a contaminação microbiológica, inclusive por Aeromonas spp.

\subsubsection{Diversidade}

$\mathrm{Na}$ atual pesquisa foi observado, nas amostras de águas e peixes analisadas, tanto para a época seca quanto chuvosa, uma elevada diversidade de espécies do gênero Aeromonas (Figura 14).

Das 18 espécies já descritas em literatura, 11 (61\%) delas foram encontradas nas amostras de água e $10(55,5 \%)$ nas amostras de peixe, independente do período (Figuras 15, 16, 17 e 18). Entre as espécies patogênicas de maior importância em saúde pública e que ocorreram em maior proporção, nas amostras de água foram: $A$. schubertii $(34,5 \%), A$. 
jandaei $(24,5 \%)$, A. trota (18\%) e A. veronii sobria $(16,3 \%)$, independente do período pesquisado (Figura 16).

Para as demais espécies mencionadas anteriormente, não foram encontrados estudos adicionais que complementassem esse resultado, provavelmente porque muitos pesquisadores ainda utilizam a classificação clássica que permite a identificação de apenas três espécies: $A$. sobria, $A$. hydrophila e A. caviae. No presente estudo, a classificação utilizada para Aeromonas spp baseou-se nos artigos mais atuais publicados até 0 momento (Quadro I).

PIANETTI e col. (2004), estudando a presença de espécies de Aeromonas em amostras de água poluída, verificaram uma maior prevalência de cepas de $A$. veronii sobria, ao contrário de $A$. hydrophila que foi a menos freqüente, o que pode ser explicado pelo fato dessa espécie ser encontrada preferencialmente em águas mais limpas. No presente trabalho A. hydrophila também foi a espécie menos isolada (Figuras 15, 16, 17 e 18), confirmando, de certa forma, o elevado grau de poluição presente nas águas dos pesqueiros analisados.

Outro ambiente em que cepas de A. v. sobria foram encontradas em grande quantidade, foi no Rio Foglia (Itália), onde as águas são comumente utilizadas para atividades recreacionais, portanto, com um elevado nivel de impacto (PIANETTI e col. 1998).

Um dos fatores ambientais que pode estar favorecendo na manutenção dessa espécie, foi sugerido por BENCHOKROUN e col. (2003), quando observaram que entre as espécies de Aeromonas pesquisadas, $A$. $v$. 
sobria mostrou-se a mais resistente aos efeitos nocivos dos raios solares quando comparada a A. hydrophila.

Outro estudo com resultados muito semelhantes ao encontrado no presente trabalho foi a pesquisa conduzida por MATTÉ, em 1995, na qual a autora observou maior prevalência de $A$. v. sobria, em águas da Represa Guarapiranga, responsável pelo sistema de abastecimento para significativa parcela da população da Região Metropolitana de São Paulo e utilizada também como local de intensa atividade recreacional, portanto, ambiente tão impactado quanto os pesqueiros estudados.

No presente estudo, outras espécies que ocorreram, porém em número reduzido foram $A$. popoffii, $A$. media, $A$. caviae e $A$. simiae (Figuras $15,16,17$ e 18), que são poucos comentados na literatura e relatados como frequêntes em amostras de água doce pesquisadas: $A$. popoffii (8\%), $A$. media $(7 \%)$ e $A$. caviae $(13 \%)$ quando comparadas a $A$. v. veronii $(44 \%)$ (SOLER e col. 2002).

Em relação às amostras de peixe estudadas, as espécies patogênicas de maior importância em saúde pública e que ocorreram em maior proporção foram: $A$. veronii sobria $(38,2 \%)$, A. schubertii $(25,6 \%), A$. trota $(20,5 \%)$ e $A$. jandaei (12\%) (Figura s 17 e 18).

GONZÁLEZ e col. (2001), também isolaram cepas de $A$. veronii sobria em pisciculturas, sendo a segunda espécie mais prevalente em amostras de Salmor trutta, Oncorhynchus mykiss e Esox lucius, . ao contrário de $A$. schubertii que foi uma das menos freqüentes. 
Resultado similar foi o relatado por BERNARDES e col. (2003), estudando a contaminação por Aeromonas spp em viveiros de pacu (Piaractus mesopotamicus).

Outra espécie isolada em amostras de peixe, porém em pequena quantidade (Figuras 17 e 18), foi a A. hydrophila, responsável por grandes prejuízos aos piscicultores. É capaz de provocar septicemia hemorrágica bacteriana nos peixes, conhecida também como "peste vermelha", "boca vermelha", "peste das enguias de água doce", "ascite infecciosa" entre outros (ALEXANDRINO de PEREZ e col. 2000, SHAO e col. 2004).

Essa espécie acomete principalmente trutas e carpas, mas sua ocorrência também já foi descrita em tilápias (Tilápia rendali, Oreochromis niloticus e Sarotherodon sp) (EASA e col. 1995, KHALIL e HUSSEIN 1997, ALEXANDRINO de PEREZ e col. 2000, GONZÁLES-RODRÍGUEZ e col 2002, VIVEKANANDHAN e col. 2003, HATHA e col. 2004).

Em 2004, HATHA e col., estudando peixes de água doce mantidos em cativeiro, observaram o predominio de $A$. hydrophila (61\%) no interior da cavidade intestinal, seguido por $A$. caviae $(30 \%)$ e A. v. sobria (7\%). Neste caso, A. v. sobria não estava entre as espécies mais prevalentes, como verificado no presente estudo.

Em relação à espécie $A$. schubertii, não há muitas referências a seu respeito, principalmente em amostras ambientais, entretanto é uma bactéria que apresenta muitos fatores de virulência como produção de amilases, proteinases, $\beta$-hemolisinas e toxinas (CARNAHAN e col. 1989, KOKKA e col. 1992). 
Apesar dessa espécie ser mais freqüentemente encontrada em amostras clínicas, no presente estudo foi uma das espécies mais prevalente (Figura 18); contudo, estava ausente na pesquisa realizada por SOLER e col. (2002) com amostras de água doce.

\subsubsection{Perfil Plasmidial}

Entre as espécies submetidas à análise do perfil plasmidial, foram encontradas as seguintes porcentagens quanto à ocorrência de pelo menos 1 plasmidio do total de cepas isoladas para cada uma dessas espécies: $A$. hydrophila $15 / 19$ (79\%), A. veronii sobria $65 / 114$ (73\%), A. jandaei $84 / 115$ (57\%), A. schubertii 103/125 (74\%), A. trota $83 / 110$ (75\%), A. bestiarium 22/29 (76\%) e A. popoffii 2/3 (67\%) (Figura 19 e Tabela 1).

Pesquisa semelhante foi realizada por BROWN e col. (1997), os quais também observaram várias cepas do gênero Aeromonas que continham pelo menos 1 plasmídio, isoladas de amostras ambientais: $A$. hydrophila (11\%), A. veronii sobria $(40 \%)$ e A. caviae. (15\%). Para MATTÉ (1996), o resultado obtido acompanhou a seguinte proporção: $A$. hydrophila $(13,4 \%)$, A. v. sobria $(33,3 \%)$ e $A$. jandaei $(53,3 \%)$, todas provenientes também de amostra ambiental sujeita a contaminação química, física e biológica.

Tanto MATTÉ (1996) como BROWN e col. (1997) não encontraram correlação entre presença de plasmidios e a produção de fatores de virulência entre as cepas estudadas. 
A Figura 20, demonstra a distribuição de espécies de Aeromonas distribuídas entre as amostras pesquisadas, onde é possivel verificar uma grande ocorrência de cepas com plasmídio, nas amostras de água e peixe. RADU e col. (2003) também verificaram plasmídios em $A$. caviae (1), $A$. hydrophila (6) e A. veronii sobria (27) isoladas de 87 amostras de Tilapia mossambica provenientes de um mercado na Malásia. Nesta pesquisa, $A$. veronii sobria estava entre as cepas que apresentou grande quantidade de plasmídios, observado também no presente estudo (Figura 19).

A variedade de tamanhos e quantidades de DNA plasmidiais encontrados podem diferir entre bactérias da mesma espécie ou não, devido a capacidade de transferência e perda de plasmidios no decorrer de sua existência. De maneira geral, a ocorrência de um maior número de plasmídios e altos pesos moleculares em um organismo, indica uma maior quantidade de informaçōes genéticas que podem estar relacionadas a capacidade de resistir a ambientes impactados.

No presente estudo, cada espécie pesquisada apresentou, de maneira geral, um perfil plasmidial caracteristico, constituido por plasmidios de vários tamanhos (Figuras 21 e 22).

A diferença entre a quantidade de bandas de DNA plasmidial encontradas para as diferentes espécies de Aeromonas, sugerem, de modo superficial, a relação entre esses elementos a cada uma das espécies analisadas, onde $A$. veronii sobria demonstrou um predomínio de 10 a 12 plasmídios (Figura 21A); A. jandaeii de 9 a 13 plasmídios (Figuras 21B e 22A); A. schubertii de 7 a 8 plasmídios (Figuras 21C e 22D); A. trota de 5 
plasmídios (Figuras 21D e 22A); $A$. bestiarium de 2 plasmídios e $A$. hydrophila de 1 a 2 plasmídios (Figura 22C). Quanto a A. popoffii, em virtude do reduzido número de cepas isoladas (3), não foi possivel identificar um predomínio de número de plasmídio como verificado nas demais espécies (Tabela 1). Embora essa análise não apresente correlação com as caracteristicas bioquímicas, pode auxiliar futuras pesquisas relacionadas à análise de perfis plasmidiais de espécies do gênero Aeromonas provenientes sobretudo de ecossistemas impactados como os pesqueiros analisados.

Apesar desse ambiente não ter favorecido o predomínio de cepas de $A$. hydrophila, foi a espécie que, proporcionalmente, apresentou mais ocorrência de pelo menos 1 plasmídio, como pode ser observado na Figura 19. Isso pode sugerir uma forma de adaptação da espécie frente ao ambiente impactado dos pesqueiros. Além disso, $47 \%$ das cepas continham plasmídios de alto peso molecular, entre 23,1 a $80 \mathrm{~kb}$, sugerindo maior quantidade de informações presentes nos genes desses plasmídios (Anexo 1).

HANES e CHANDLER (1993), estudando cepas de A. hydrophila resistentes a novobiocina e carbenicilina, verificaram que os genes responsáveis por essa resistência estavam presentes no DNAplasmidial e não no DNAcromossomal como se pensava.

Alguns autores verificaram que essas formas de resistência em isolados de $A$. hydrophila estavam relacionadas ao resultado de 
transferência de genes a partir de cepas de Escherichia coli (SON e col. 1997 e WARREN e col. 2004).

Nessa mesma linha de pesquisa, RHODES e col. (2000), pesquisando a distribuição geográfica de plasmídios relacionados a resistência a oxitetraciclina entre cepas de Aeromonas spp e $E$. coli procedentes de hospitais e pisciculturas, concluiram que esses dois sistemas representavam um único compartimento de grande interação e que estava funcionando como um importante disseminador potencial de plasmídios.

Esses estudos inferem uma importante relação entre presença de plasmídios e resistência a diferentes agentes antimicrobianos, que pode ocorrer em ambientes impactados, demonstrando, com isso, a necessidade de mais pesquisas voltadas ao gênero Aeromonas, especialmente sobre assuntos relacionados à presença de plasmídios codificadores de diferentes tipos de resistência bem como a sua capacidade de recepção e transferência entre bactérias intra e interespecificas. A ocorrência desses plasmidios em bactérias alóctones ou autóctones do ambiente aquático representa uma enorme preocupação de interesse em saúde pública, como verificado também por MATTÉ (1996), PICKUP e col. (2003), HATHA e col. (2004). 


\subsection{Aspectos de Interesse em Saúde Pública}

\subsubsection{Qualidade da Água}

Em face dos resultados obtidos como a ocorrência de elevadas contagens de indicadores de contaminação fecal acima do limite preconizado pelo CONAMA e pela presença de cepas patogênicas de Salmonella spp e Escherichia coli, bem como da alta prevalência de bactérias patogênicas autóctones do ambiente aquático, como o gênero Aeromonas, é fundamental o controle e manejo adequado das águas e peixes pertencentes a esse tipo de sistema de pesca esportiva denominado pesque-pague.

Deficiências em relação ao controle e manejo adequado também foram verificadas em outros pesqueiros do tipo pesque-pague do Estado de São Paulo, onde proprietários e funcionários, a maioria, desqualificados não tinha conhecimento sobre algumas questōes básicas como quantidade de peixes introduzidos no sistema, necessidade de oxigenação, tratamento dos residuos de peixe e esgoto doméstico de modo a evitar a disseminação de doenças, prevalecendo, no entanto, métodos do tipo tentativa e erro (KITAMURA e col. 1999, VENTURIERI 2002).

Esses autores observaram que de forma geral, os resultados indicaram baixa qualidade da água utilizada nos pesqueiros, dado confirmado também no presente estudo, onde mais da metade dos estabelecimentos, no periodo seco, estavam em desacordo com os limites 
microbiológicos recomendados, tanto para contagens de coliformes fecais quanto para presença de Salmonella spp (Figura 11).

Uma das vias de contaminação por esses organismos entéricos pode estar relacionada a diversas fontes como a influência das chuvas no carreamento de fezes de animais domésticos ou selvagens (garças e lontras) que circulam próximos às lagoas e de adubo orgânico proveniente de atividades agrícolas nas proximidades dos pesqueiros, dois aspectos observados em $75 \%$ dos pesqueiros estudados (ESTEVES e col. 2003); ou então despejo de matéria orgância, bem como o lançamento de águas de transporte pré-contaminadas originárias de ecossistemas aquáticos artificiais ou naturais de outras localidades (CRABILL e col. 1997, KITAMURA e col. 1999, VENTURIERI 2002, ALEXANDRINO de PEREZ e CARVALHO FILHO 2003, KELSEY e col. 2004).

Diante do exposto, é fundamental que os piscicultores estejam muito atentos a todas essas possiveis rotas de contaminação, uma vez que quanto maior a quantidade de poluentes nas águas dos pesqueiros, maior será a taxa de doenças e mortalidade dos peixes (KHALIL e HUSSEIN 1997. KOLAR e LODGE 2001, GUZMÁN e col. 2004).

Diante de um ambiente estressante com elevada quantidade de material fecal, nutrientes, algas fotossintetizantes, agentes antimicrobianos, além de elevada densidade íctiia, deficiência de oxigênio dissolvido e baixa qualidade dos alimentos, os peixes tornam-se vulneráveis ao ataque de microrganismos, especialmente bactérias (MARKOOVÁ e JEEK 1994, ALHARBI e UDDIN 2004, CONTE 2004, EL-SHAFAl e col. 2004). 
As bactérias são capazes de ultrapassar as barreiras protetoras, tais como o muco encontrado na superfície do corpo e os glóbulos brancos presentes nas brânquias e intestino, atingindo, desse modo, os diferentes tecidos e órgãos desses animais (OGBONDEMINU e OKOYE 1992, PAUL e DAS GUPTA 1992, FATALL e col. 1993, KHALIL e HUSSEIN 1997, GUZMÁN e col. 2004).

Esse tipo de contaminação, especialmente a bacteriana, aos quais os peixes estão susceptiveis, torna-se mais grave quando se considera o crescente número de bactérias nesse tipo de sistema de aqüicultura, cada vez mais resistentes às múltiplas substâncias antimicrobianas.

Apenas $6,7 \%$ dos proprietários confirmaram a utilização de antibióticos em suas lagoas (ESTEVES e col. 2003), porém sabe-se que essa prática é largamente empregada entre os piscicultores como medida preventiva de enfermidades que acometem os peixes (CDC 1999, VIVEKANANDHAN e col. 2002, LALUMERA e col. 2004).

Diversos autores têm relatado a ocorrência de enterobactérias e espécies do gênero Aeromonas isoladas do ambiente aquático ou de amostras de peixes, resistentes a inúmeros antibióticos, incluindo não somente aqueles recomendados pelo Ministério da Agricultura e do Abastecimento disposto na Instrução Normativa $n^{\circ} 42$ de 20/12/99 para uso na aqüicultura (tetraciclina, eritromicina e oxitetraciclina), como também a carbenicilina, estreptomicina, cloranfenicol, ampicilina, bacitracin, cefalotina, cefoxitina, amoxicilina, lincomicina, meticilina, novobiocina, oxacilina, penicilina, 
rifampicina e trimetoprim-sulfametoxazol, vancomicina, kanamicina, sulbactam-ampicilina, gentamicina, polimixina B, ciprofloxacina, flouroquinolona e cefalosporina (ARVANITIDOU e col. 1997, URRIZA e col. 2000, SOLER e col. 2002, VIVEKANANDHAN e col. 2002, COSTA 2003, RADU e col. 2003, YAN e col. 2003).

Apesar de a maioria dos proprietários não terem confirmado o uso de antibióticos nas águas dos pesqueiros estudados, estes relataram a utilização de alguns produtos em caso de doenças, como dimilin, sal grosso, formol e sulfato de cobre (ESTEVES e col. 2003). Embora não tenha havido correlação estatisticamente significativa entre esses produtos e número de cepas isoladas de Aeromonas e enterobactérias pesquisadas, foi possível observar várias cepas de Aeromonas spp contendo plasmidios que são estruturas relacionadas à resistência aos diversos tipos de agentes antibactericidas (Figuras 21 e 22).

Assim, pode-se sugerir que a ocorrência desses elementos extracromossômicos nas cepas de Aeromonas spp analisadas, podem estar relacionada às diversas substâncias antimicrobianas e ao elevado grau de eutrofização (MERCANTE e col. 2004) e contaminação fecal presentes nas águas dos pesqueiros estudados.

Embora a presença desses plasmidios nas células bacterianas não seja uma condição vital para sua sobrevivência, pode aumentar as suas chances de sobrevivência quando mantidas em ambientes impactados como os sistemas intensivos de pesca. 
Até mesmo para bactérias alóctones ao ecossistema aquático, como as enterobactérias, DNA plasmidial não analisado na presente pesquisa, alguns autores relataram que essas bactérias carregam plasmídios em suas células bem como possuem a capacidade de transferilos a outras bactérias do mesmo gênero ou não, como as Aeromonas spp (ARANA e col 1997, ALM e col 2003, PICKUP e col. 2003, HATHA e col. 2004 e WARREN e col. 2004).

Diante dessas informações, verifica-se que o manejo dessas águas destinadas à recreação devem ser muito bem administrada, uma vez que qualquer alteração física, química ou biológica, refletirá sobre a comunidade microscópica e macroscópica do meio aquático, muitas vezes não perceptivel a curto prazo.

\subsubsection{Qualidade do Peixe}

A ocorrência de contagens de coliformes fecais, acima do limite preconizado pelo CONAMA $\left(10^{3} \mathrm{MNP} / 100 \mathrm{~mL}\right)$, o qual equivale ao mesmo valor recomendado pela Organização Mundial da Saúde (WHO 1989), é muito importante como parâmetro indicador da qualidade da água, uma vez que elevados niveis de coliformes fecais nas águas de pesqueiros podem comprometer a qualidade microbiológica dos peixes.

Diversos autores relataram a ocorrência de coliformes fecais, Escherichia coli, Salmonella spp e Aeromonas spp em peixes provenientes 
do sistema aquícola não somente na pele dos peixes (tilápias, em sua maioria), mas nas brânquias, no intestino, figado, rins e musculatura, principalmente porque a contagem de coliformes fecais nas águas onde os peixes eram mantidos, chegava próxima a $10^{3} \mathrm{UFC} / 100 \mathrm{~mL}$ ou superiores a esta (POLPRASERT e col. 1984, MARA e CAIRNCROSS 1989, OGBONDEMINU e OKOYE 1992, PAL e DAS GUPTA 1992, FATALL e col. 1993, EASA e col. 1995, KHALIL e HUSSEIN 1997, GONZÁLEZ e col. 2001, SORUM e L'ABÉE-LUND 2002, LIMA e REIS 2002, VIVEKANANDHAN e col. 2003, AL-HARBI e UDDIN 2004, EL-SHAFAI e col. 2004, GUZMÁN e col. 2004, HATHA e col. 2004).

Essa informação é muito importante, principalmente porque se pensava que a esterilidade era condição inerente do tecido muscular dos peixes (OGAWA e MAIA 1999). Em pisciculturas e sistemas de pesca esportiva, onde os peixes permanecem confinados por um certo tempo e ao final são destinados ao consumo, é fundamental que a qualidade microbiológica de suas águas sejam constantemente monitoradas por técnicos especializados.

No presente estudo, $30 \%$ dos pesqueiros analisados apresentou contagens de coliformes fecais, em suas águas, acima do permitido pelo CONAMA $\left(10^{3} \mathrm{MNP} / 100 \mathrm{~mL}\right)$, resultado que influenciou a contagem de coliformes fecais sobre a superficie das tilápias pesquisadas da seguinte maneira: $63,3 \%$ dos pesqueiros apresentaram pelo menos 1 amostra de

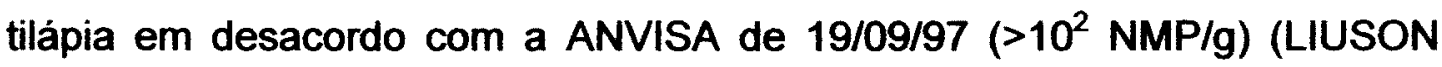
2003). 
Esses dados são muito importantes pois indicam que mesmo que a qualidade da água de um pesqueiro esteja em acordo com a legislação, não significa que os peixes também estarão, já que a proporção observada de pesqueiros em desacordo com a legislação, para cada uma das amostras, não foi semelhante, tanto que não foi verificada correlação estatisticamente significativa entre as amostras de água e peixe fora do padrão permitido $(p>0,05)$.

Em face das informações acima, verifica-se que uma grande quantidade das tilápias provenientes dos pesqueiros analisados apresentou elevadas contagens de coliformes fecais sobre a sua superfície (LIUSON 2003). Essa contaminação, entretanto, pode ser muito mais generalizada, ou seja, outras regiōes do peixe podem estar contaminadas, uma vez que esses animais se encontram em condição de estresse, o que determina enfraquecimento de seu sistema de defesa e também porque muitos alimentavam-se do sedimento (ESTEVES e col. 2003).

Esse comportamento alimentar das tilápias favorece a ocorrência de uma flora microbiana predominantemente constituída por enterobactérias (E. coli, Salmonella spp) e por Aeromonas spp, que uma vez no trato intestinal podem contaminar o tecido muscular como relatado por AL-HARBI e UDDIN (2004).

A sobrevivência desses organismos nos sedimentos é favorecida pela baixa temperatura e ausência de radiação solar, elevada presença de nutrientes e proteção contra ação de predadores, funcionando como um verdadeiro reservatório poluidor do ambiente e potencial risco à saúde dos 
peixes e dos consumidores (CRABILL e col 1999, LINDER e col 1999, AN e col. 2002, ALM e col. 2003, AL-HARBI e UDDIN 2004).

Em vista dessas informaçōes, os usuários de pesque-pague devem estar atentos quanto à escolha dos pesqueiros, não se importando somente com a piscosidade; mas com a transparência da água;.comportamento natatório dos peixes e presença de animais próximos às lagoas. Como consumidores devem tomar muito cuidado com o manuseio correto desse alimento proveniente de águas, muitas vezes, inadequadas para a prática da atividade.

De modo geral, uma das medidas que podem auxiliar na manutenção de peixes mais sadios dentro de um ambiente de lagoas como os pesque-pague são: a inexistência de animais de pequeno e grande porte à montante das lagoas de pesca; o lançamento, em excesso, de matéria orgânica (ração); altas densidades de peixes em qualquer um dos períodos do ano; utilização apenas de águas de nascente; aumento da capacidade de vazão entre os lagos; limpeza periódica dos tanques e monitoramento da qualidade das águas e dos peixes utilizados.

\subsubsection{Boas Práticas de Manipulação}

Foi constatado em vários paises, que a maioria dos surtos de toxinfecções alimentares estava relacionada ao consumo do pescado, resultado do manuseio inadequado do alimento, sobretudo em 
estabelecimentos comerciais com serviço de restaurante e até mesmo em lares, durante o preparo de refeições GERMANO e col. (1993).

As precauções com o consumo de alimentos provenientes de atividades recreacionais como os pesque-pague, devem ser redobradas, uma vez que, representam uma importante rota de contaminação ao homem por dispersarem patógenos aquáticos capazes de provocar graves impactos na economia e na saúde pública, como mencionados anteriormente,

O consumidor deve ser cuidadoso nos procedimentos empregados, desde o momento da captura dos peixes até o momento de consumi-los.

Após a morte do peixe, inicia-se a autólise determinada por suas próprias enzimas. Durante esse estágio, o número de microrganismos presentes sobre a pele, brânquias e no interior da cavidade intestinal aumentam rapidamente com a penetração em vários tecidos através do sistema vascular, os quais liberam enzimas, iniciando a etapa de decomposição. Por isso, devem ser acondicionados em isopor juntamente com gelo em pequenos pedaços para que a maior parte da superfície dos peixes permaneça refrigerada.

É fundamental que o gelo utilizado seja de boa qualidade, proveniente de água potável, para que o peixe não se contamine com microrganismos presentes nesse produto (VIEIRA e col. 1997, PIMENTEL 2000, FALCÃO e col. 2002).

Falcão e col. (2002), analisando a qualidade microbiológica de gelos provenientes de seis estabelecimentos comerciais do município de 
Araraquara, São Paulo, puderam isolar cepas de E. coli e Salmonella Enteritidis. Igualmente, VIEIRA e col. (1997) isolaram espécies patogênicas de Aeromonas em gelo utilizado em mercados de peixe no município de Mucuripe, Fortaleza

O gênero Aeromonas apresenta uma grande capacidade de sobreviver a baixas temperaturas, variando entre 2 e $10^{\circ} \mathrm{C}$, principalmente em alimentos rico em proteínas como a carne de peixes (CASTROESCARPULLI e col. 2003). Essas bactérias têm sua patogenicidade aumentada com o decréscimo da temperatura em decorrência do aumento da expressividade de seus fatores de virulência (KIROV 1997).

O manipulador deve ser cuidadoso ao manusear o peixe recém capturado, já que a carga microbiana presente no animal é extremamente elevada, sendo mais acentuada quanto maior o grau de poluição das águas. Os microrganismos presentes na superficie, nas guelras e vísceras dos peixes representam uma potente fonte de contaminação que pode ocorrer durante a manipulação do peixe. (EASA e col. 1995, GONZÁLEZ e col. 2001, RADU e col. 2003, CONTE 2004, EL SHAFAl e col. 2004, GUZMÁN e col. 2004).

Em grande parte dos pesqueiros, oferece-se o serviço de limpeza e filetamento dos peixes, porém na maioria das vezes, essa manipulação do peixe é realizada por funcionários sem o menor preparo e conhecimento sobre as boas práticas de manipulação, comprometendo a qualidade dos filés, principalmente através da contaminação cruzada (VENTURIERI 2002). 
A contaminação cruzada é extremamente perigosa, especialmente se o peixe não for submetido a uma cocção adequada ou se for ingerido cru como sashimi, prato da culinária japonesa que vem se popularizando muito no Brasil e que costuma ser preparado em vários estabelecimentos pesqueiros do Estado de São Paulo (GERMANO 1993, VENTURIERI 2002, HAMADA-SATO e col. 2004).

Além do perigo da contaminação cruzada, o tecido muscular desses peixes já pode estar contaminado por microrganismos patogênicos resistentes provenientes do próprio ambiente dos quais o peixe advém, como descrito anteriormente, potencializando ainda mais o risco à saúde dos consumidores.

Esse prato está associado a diversos surtos de gastrenterites de origem alimenticia relacionado, sobretudo ao gênero Aeromonas, em especial a $A$. hydrophila, tanto que, em 1984, a FDA (Food Drug Administration) incluiu a espécie na lista dos principais patógenos de origem alimentar (ISONHOOD e DRAKE 2002).

Considerando a discussão de todas essas informações referentes à ocorrência de indicadores fecais nas águas dos pesqueiros, contaminações dos peixes pelo excesso de carga microbiológica, presença de bactérias patogênicas emergentes de interesse em saúde pública e principalmente o manejo inadequado praticado nesse tipo de sistema, destinado ao lazer e sobretudo ao consumo do peixe capturado, mais pesquisas devem ser estimuladas em relação à qualidade microbiológica de águas de pesqueiros, que são extremamente escassos tanto no Brasil 
quanto em outros países, a fim de alertar e orientar de forma correta os piscicultores, proprietários de pesqueiros tipo pesque-pague e os usuários. 


\section{CONCLUSÕES}

O presente estudo permitiu concluir que:

- No periodo seco, mais da metade $(53,3 \%)$ dos estabelecimentos estavam com a qualidade microbiológica de suas águas comprometida para o exercicio da atividade, segundo presença de coliformes fecais, considerando o limite estabelecido pelo CONAMA No 20 de 01/06/86, e ocorrência de cepas de Salmonella spp; enquanto que na fase chuvosa, essa proporção foi de $33,3 \%$.

- Verificou-se que as provas bioquímicas (IAL) e sorológicas não evitaram alguns resultados falso positivos, confirmados posteriormente pela técnica molecular, a qual possibilitou a identificação de 14 (58\%) cepas em nivel de gênero, de um total de 24 cepas positivas para Salmonella spp, identificadas a partir de provas bioquímicas. A pesquisa não demonstrou a presença de Salmonella Enteritidis e Salmonella Typhimurium.

- Uma alta proporção de pesqueiros $(>80 \%)$ continha cepas de Aeromonas spp presentes em suas águas, tanto no período seco quanto chuvoso.

- As espécies de Aeromonas spp patogênicas mais prevalentes nas amostras de água na fase seca foram: $A$. jandaei $(24,5 \%), A$. trota (18\%) e $A$. veronii sobria (16,3\%), enquanto que na fase chuvosa foram: A schubertii (34,5\%), A. veronii sobria $(10,5 \%)$ e $A$. jandaeii $(10 \%)$.

- As espécies de Aeromonas spp patogênicas mais prevalentes nas amostras de peixe na fase seca foram: $A$. veronii sobria $(38,2 \%), A$. 
trota $(20,5 \%), A$. jandaeii $(12 \%)$, enquanto que na fase chuvosa foram: A schubertii $(25,6 \%)$, A. jandaei $(10,5 \%)$ e A.trota (10\%).

- Uma alta proporção de cepas atípicas de Aeromonas (Aeromonas spp) foram identificadas nas amostras de água $(19,5 \%)$ e peixe $(25,6 \%)$.

- Entre as cepas pesquisadas, as espécies que apresentaram pelo menos 1 plasmídio, em ambos amostras (água e peixe) e periodos (seco e chuvoso), foram: $A$. hydrophila (79\%), A. veronii sobria $(73 \%)$, A. jandaei (57\%), A. schubertii (74\%), A. trota (75\%), A. bestiarium $(76 \%)$ e A. popoffii (67\%), sugerindo a existência de genes relacionados à resistência nessas bactérias.

- Não foi verificada correlação entre coliformes fecais e ocorrência de Aeromonas spp em nenhuma das épocas estudadas $(p>0,05)$.

- Não foi verificada correlação entre cepas de Salmonella spp e ocorrência de Aeromonas spp em nenhuma das épocas estudadas $(p>0,05)$. 


\section{Recomendações Gerais}

- Deve-se evitar o lançamento de matéria orgânica em excesso nas águas dos pesqueiros, de modo que a saúde dos peixes mantenha-se em equilíbrio.

- A presença de animais próximos a lagoas localizadas a montante das lagoas de pesca devem ser evitados para que as mesmas não sejam contaminadas por material de origem fecal.

- E aconselhável um monitoramento periódico da qualidade microbiológica das águas dos pesqueiros desde que realizada por um profissional competente.

- Deve-se restringir o uso abusivo de agentes antimicrobianos nas águas das lagoas, para que se evite a evolução de linhagens mais resistentes de bactérias. $\mathrm{O}$ tratamento preventivo ou curativo dos peixes, deve ser orientado por um veterinário qualificado.

- É fundamental a limpeza periódica dos tanques e a retirada do sedimento, para que se previna doenças em peixes que venham a se alimentar de sedimento. 


\section{REFERÉNCIAS}

Aabo S, Rasmussen OF, Rossen L, Sorensen PD, Olsen JE. Salmonella identification by the polymerase chain reaction. Mol Cell Probes 1993; 7 : 171-178.

Abbott SL, Cheung WKW, Janda JM. The genus Aeromonas: biochemical characteristics, atypical reactions, and phenotypic identification schemes. Clin Microbiol 2003; 41 (6): 2348-2357.

Agarwal A, Makker A, Goel SK. Application of the PCR technique for a rapid, specific and sensitive detection of Salmonella spp in foods. Mol Cell Probes 2002; 16: 243-250.

Alberts B, Bray D, Johnson A, Lewis $J$, Raff $M$, Roberts $K$ et al. Fundamentos da biologia celular - uma introdução à biologia molecular da célula. $2^{\mathrm{a}}$ ed. Porto Alegre: ARTMED , 2002.

Alexandrino de Perez AC, Carvalho Filho AC. Manual de procedimentos higiênicos e sanitários para a criação de peixes saudáveis. São Paulo; 2003 [Manual do Programa de Pesquisa em Políticas Públicas - Secretaria da Agricultura e Abastecimento do Estado de São Paulo].

Alexandrino de Perez AC, Okumura MP, Baldassi L, Kuroda CK, Wakasa YS. Ocorrência de Aeromonas hydrophila em Truta arco-íris (Oncorhynchus mykiss) e cultivo intensivo - relato de caso. B Inst Pesca 2000; 26 (1): 117119.

Alexandrino de Perez AC. Manual de prevenção de doenças em pisciculturas. São Paulo; 1998 [Boletim Técnico 23 - Instituto de Pesca da Secretaria da Agricultura e Abastecimento].

Al-Harbi AH, Uddin MN. Seasonal variation in the intestinal bacterial flora of Irbid tilapia (Oreochromis niloticus $\times$ Oreochromis aureus) cultured in earthen ponds in Saudi Arabia. Aquaculture 2004; 229: 37-44. 
Ali A, Carnahan AM, Altwegg M, Lüthy-Hottenstein J, Josephe J. Aeromonas bestiarium sp nov. (formely genomospecies DNA group 2 A. hydrophila), a new species isolated from non-human sources. Med Microbiol Lett 1996; 5: 156-65.

Allen DA, Austin B, Colwell RR. Aeromonas media, a new species isolated from river water. Int J Syst Bacteriol 1983; 33: 599-604.

Alm EW, Burke J, Spain A. Fecal indicator bacteria are abundant in wet sand at freshwater beaches. Wat Res 2003; 37: 3978-3982.

Altwegg $M$, Geiss HK. Aeromonas as an human pathogen. Crit Vet Microbiol 1989; 16: 253-286.

American Public Health Association. Standard Methods for the Examination of Water and Wastewater. $19^{\text {th }}$ ed. Washington: APHA, 1995.

An Y-J, Kampbell DH, Breidenbach GP. Escherichia coli and total coliforms in water and sediments at lake marinas. Environ Pollut 2002; 120: 771-778.

An Y-J, Kampbell DH, Sewell GW. Water quality of three marinas in Lake Texoma. Trans Am Geo Union 2000; 81 (Suppl 48): F 385.

Anonymus. Pesca em águas contaminadas. Rev FAPESP 2004; 97:62.

Arana I, Justo JI, Muela A, Pocino M, Iriberri J, Barcina I. Influence of a survival process in a freshwater system upon plasmid transfer between Escherichia coli strains. Microbiol Ecol 1997; 33: 41-49.

Arvanitidou M, Tsakris A, Constantinidis TC, Katsouyannopoulos VC. Transferable antibiotic resistance among Salmonella strains isolated from surface waters. Wat Res 1997; 31 (5): 1112-1116.

Ashbolt NJ, Grabow WOK, Snozzi M. Indicators of microbial water quality. In: Fewtrell L e Bartram J editors. Water quality: guidelines standards and health (WHO) London: IWA Publishing; 2001. p. 289-316 
Ausubel FM, Brent R, Kingston RE, Moore DD, Seidman JG, Smith JA e col. Short Protocols in Molecular Biology. $3^{\text {th }}$ ed. United States: John Wiley \& Sons, 1995.

Back CN, Pinheiro A, Reibnitz MGR. Estudo microbiológico das águas efluentes de viveiros de peixe. [documento on line] 1998. Disponivel em: <URL:http://www.ufsc.br/ccb> [2004 abr 18].

Barnes AC, Hasting TS, Amyes GB. Amoxicilinn resistance in Scottish isolates of Aeromonas salmonicida. J Fish Dis 1994; 17: 357-363.

Bauab TM, Fernandes M, Falcão DP. Marcadores de virulência em Aeromonas spp isoladas de materiais clínicos humanos e de água doce. Ver Cienc Farm 2001; 22 (1): 131-145.

Benchokroun S, Imziln B, Hassani L. Solar inactivation of mesophilic Aeromonas by exogenous photooxidation in high-rate algal pond treating waste water. J Appl Microbiol 2003; 94: 531-538.

Bernardes MVS, Mesquita AJ, Silva PC, Rios ER, Macedo MC, Borges GT et al. Aeromonas spp em viveiros de criação intensiva de pacu (Piaractus mesopotmicus). [Apresentado no XXII Congresso Brasileiro de Microbiologia, 2003 novembro 17-20; Florianópolis, Santa Catarina, Brasil].

Birnboim, HC, Doly JA. Rapid alkaline extraction procedure for screening recombinant plasmid DNA. Nucleic Acid Res 1979; 7(6): 1513.

Borchardt, MA, Stemper ME, Standridge. Aeromonas isolates from human diarrheic stool and groundwater compared by pulsed-field gel electrophoresis. Em Infect Dis 2003; 9 (2): 224-228.

Brandi G, Sisti M, Schiavano GF, Salvaggio L, Albano A. Survival of Aeromonas hydrophila, Aeromonas caviae e Aeromonas sobria in soil. $\mathbf{J}$ Appl Bacteriol 1996; 81: 439-444. 
Brasil, MAA. Plano nacional de controle de residuos em produtos de origem animal - Instrução normative $n^{\circ} 42$ de 20 de dezembro de 1999.

BrasilL MMA. Conselho Nacional do Meio Ambiente - CONAMA. Resolução $n^{\circ} 20$ de 18 de junho de 1986. Diário Oficial da União de 30/7/86. Classificação das águas doces, salobras e salinas do território Nacional. Disponivele m<URL:http://www.mma.gov.br/port/conama/res/res86/res2086. html> [2001 set 23].

Brown RL, Sanderson K, Kirov SM. Plasmids and Aeromonas virulence. FEMS Immunol Med Microbiol 1997; 17:217-23.

Bulhões CCC, Rossi Júnior $O D$. Ocorrência de bactérias do gênero Aeromonas em queijo-de-minas frescal artesanal. Arq Bra Med Vet Zootec 2002; 54 (3).

Cabral A. Diversidade de Aeromonas spp em ambientes aquáticos do Estado de São Paulo. São Bernardo do Campo-SP; 2000. [Monografia Faculdade de Ciências Biológicas e da Saúde da Universidade Metodista de São Paulo].

Carnahan AM, Behram S, Joseph SW. Aerokey II: A flexible key for identifying clinical Aeromonas species. J Clin Microbiol 1991a; 29 (12): 2843-49.

Carnahan AM, Chakraborty T, Fanning GR, Verma D, Ali A, Janda JM, Joseph SW. Aeromonas trota sp. nov., an ampicillin - susceptible species isolated from clinical specimens. J Clin Microbiol 1991b; 29 (6): 1206-10.

CARNAHAN AM, MARIL MA, FANNING GR, PASS MA, JOSEPH SW. Characterization of Aeromonas schubertii strains recently isolated from traumatic wound infections. J Clin Microbiol 1989; 27 (8): 1826-1830.

Castro-Escarpulli G, Figueras MJ, Aguilera-Arreola G, Soler L, FernandezRendón, Aparicio GO et al. Characteriation of Aeromonas spp isolated from 
frozen fish intended for human consumption in Mexico. Int J Food Microbiol 2003; 84: 41-49.

Centers for Disease Control and Prevention. Surveillance for waterbornedisease outbreaks - United states 1999-2000. MMWR 2002; 51: 1-28.

Centers for Disease Control and Prevention. Use of antimicrobial agents in aquaculture: potential for public health impact [documento on line] 1999. Avaliable from:<URL:http://www.natlaquaculture.org/pdf/cdc520Memo\%20to $\% 20$ the $\% 20$ Record.pdf.htm> [2004 set 16].

Chapman PA, Ellin M, Ashton R, Shafique W. Comparison of culture, PCR and immunoassays for detecting Escherichia coli $O 157$ following enrichment culture and immunomagnetic separation performed on naturally contaminated raw meat products. Int J Food Microbiol 2001; 68: 11-20.

Chopra I, O'Neill AJ, Miller K. The role of mutators in the emergence of antibiotic-resistant bacteria. Drug Resist Updates 2003; 137-145.

Colwell RR, Macdonell MT, Deley J. Proposal to recognize the family Aeromonadaceae fam. Nov. Int J Syst Bacteriol 1986; 36 (3): 473-7.

Conte FS. Stress and the welfare of cultured fish. Appl Anim Behav Sci 2004; 86: 205-223.

Costa AB. Caracterização de bactérias do complexo Aeromonas isoladas de peixes de água doce e sua atividade patogênica. Piracicaba-SP; 2003. [Tese de Doutorado - Escola Superior de Agricultura "Luiz de Queiroz" da USPI.

Crabill C, Donald R, Snelling J, Foust R, Southam G. The impact of sediment fecal coliform reservoirs on seasonal water quality in Oak Creek, Arizona. Wat Res 1999; 33 (9): 2163-2171.

D' Aoust JY. Salmonella species. In: Doyle MP et al., editors. Food microbiology, fundamentals and frontiers. $1^{\text {st }}$ ed. Washington: ASM Press; 1997. p. 135-136. 
Dalsgaard I, Nielsen B, Larsen JL. Characterization of Aeromonas salmonicida subsp. salmonicida: a comparative study of strains of different geographic origin. J Appl Bacteriol 1994; 77: 21-30.

Defrancesco KA, Cobbold RN, Rice DH, Besser TE, Hancock DD. Antimicrobial resistance of commensal Escherichia coli from dairy cattle associated with recent multi-resistant salmonellosis outbreaks. Vet Microbiol 2004; 98: 55-61.

Dorsch M, Ashbolt NJ, Cox PT, Goodman AE. Rapid identification of Aeromonas species using 165 rDNA targed oligonucleotide primers. A molecular approach based on screening of environmental isolates. J Appl Bacteriol 1994; 77: 722-6.

Doyle MP, Zhao T, Meng J, Zhao. Food Microbiology, fundamental and frontiers. Washington: ASM Press; 1997. p. 171.

Dumontet S, Krovacek K, Baloda SB, Grottoli R, Pasquale V, Vanucci S. Ecological relationship between Aeromonas and Vibrio spp and planktonic copepods in the coastal marine environment in southern Italy. Comp Immunol Infect Dis 1996; 19 (3): 245-254

Easa M El-S, Shereif MM, Shaaban Al, Mancy KH. Public health implications of waste water reuse for fish production. Wat Sci Tech 1995; 11: 145-152.

El-Shafai SA, Gijzen HJ, Nasr FA, El-Gohary FA. Microbial quality of tilapia reared in fecal-contaminated ponds. Environ Res 2004; 95: 231-238

Elzéby JP. Revised Salmonella nomenclature: designation of Salmonella enterica (ex Kauffmann and Edwards 1952) Lê Minor and Popoff 1987 sp nov nom ver as the neotype species of the genus Salmonella Lignieres 1900 (Approved Lists 1980), rejection of the name Salmonella choleraesuis (Smith 1894) Weldin 1927 (Approved Lists 1980), and conservation of the name Salmonella typhi (Schroeter 1886) Warren and Scott 1930 (Approved Lists 1980). Request for an opinion. Int J Syst Bacteriol 1999; 49: 927-930. 
Ervik A, Thorsen B, Eriksen V, Lunestad BT, Samuelsen OB. Impact of administering antibacterial agents on wild fish and blue mussels Mytilus edulis in the vicinity of fish farms. Dis Aqua Org 1994; 18: 45-51.

Esteve C, Gutiérrez MC, Ventosa A. Aeromonas encheleia sp nov., isolated from European eels. Int J Syst Bacteriol 1995; 45 (3): 462-6.

Esteves KE, Mercante CT, Sant'ana CL, Azevedo MP, Matté MH, Balian SC et al. Diagnóstico ecológico-sanitário de pesqueiros da região metropolitana de São Paulo. São Paulo: FAPESP; 2003. (Processo 01/04081-8)

Falcão DP, Lustri WR, Bauab TM. Incidence of non-O1 Vibrio cholerae and Aeromonas spp. in fresh water in Araraquara, Brazil. Curr Microbiol 1998; 37: 28-31.

Falcão JP, Dias AMG, Correa EF, Falcão DP. Microbiological quality of ice used to refrigerate foods. Food Microbiol 2002; 19: 29-276.

Fatall B, Dotan A, Parpari L, Tchorsh Y, Cabelli VJ. Microbiological purification of fish grown in fecally contaminated commercial fishpond. Wat Sci Technol 1993; 27: 303-311.

Garrit GM, Winters M, Searles DB. Taxonomic outline of the procaryotic genera Bergey's manual of systematic bacteriology [document on line].Bergey's manual trust. $2^{\text {nd }}$ ed. Version 4.01. New York: Springer-Verlag; 2001. Available from <URL: http://www.cme.msu.edu/bergeys/april/2001genus.pdf>.[2004 fev 26].

Gauthier F, Archibald F. The ecology of "fecal indicator" bacteria commonly found in pulp and paper mill water systems. Wat Res 2001; 35: 2207-2218.

Gavriel AA, Landre JPB, Lamb AJ. Incidence of mesphilic Aeromonas within a public drinking water supply in north-east Scotland. J Appl Microbiol 1998; 84: $383-392$ 
Germano PML, Oliveira, JCF, Germano, MIS. O pescado como causa de toxinfecções bacterianas. Higiene Alimentar 1993; 7 (28): 40-45.

Gibott A, Saridakis HO, Pelayo JS, Tagliari KC, Falcão DP. Prevalence and virulence properties of Virio cholerae non-O1, Aeromonas spp. and Plesiomonas shigelloides isolated from Cambé stream (State of Paraná, Brazil). J Appl Microbiol 2000; 89: 70-5.

Gonzáles-Rodriguez MN, Sanz JJ, Santos A, Otero A, López-García ML. Foodborne pathogenic bacteria in prepackaged fresh retail portions of farmed rainbow trout and salmon stored at $3^{\circ} \mathrm{C}$. Int J Food Microbiol 2002; 76: 135 141.

González CJ, Santos JA, Garcia-Lópes ML, Gonzáles N, Otero A. Mesophilic aeromonads in wild and aquacultured freshwater fish. J Food Prot 2001; 64 (5): 687-691.

Gooding CM e Choudary PV. Comparison of different primers for rapid detection of Salmonella using the polymerase chain reaction. Mol Cell Probes 1999; 13: 341-347.

Grassi MA, Civera T, Turi RM. Isolation of cytotoxic Aeromonas spp from food. Vet Res Comm 2003; 27: 305-306.

Graziano da Silva J. O novo rural brasileiro. Campinas-SP: UNICAMP-IE; 1999. Coleção pesquisas, 1 ; p. 93-100.

Guzmán MC, Bistoni MA, Tamagnini LM, Gonzáles RD. Recovery of Escherichia coli in fresh water fish, Jenynsia multidentata and Bryconamericus iheringi. Wat Res 2004; 38: 2368-2374.

Hamada-Sato N, Kazushige U, Kobayashi T, Imada C, Watanabe E. Quality assurance of raw fish base on HACCP concept. Food Control [periódico on line] 2004. Availiable from: <URL: Http://www.sciencedirect .com> [2004 Out 21]. 
Hanes DE, Chandler DKF. The role of a 40-megadalton plasmid in the adherence and hemolytic properties of Aeromonas hydrophila. Microbial Pathog 1993; 15: 313-317.

Hanninen ML, Oivanen P, Hirvelä-Koski V. Aeromonas species in fish, fisheggs, shrimp and freshwater. Int J Food Microbiol 1997; 34: 17-26.

Harf-Monteil C, Le Flèche A, Riegel P, Prevost G, Bermond D, Grimont PAD et al. Aeromonas simiae sp. nov. isolated from monkey faeces. IJSEM 2004; 54: 481-485.

Hatha M, Vivekanandhan AA, Joice GJ, Christol. Antibiotic resistance pattern of motile aeromonads from farm raised fresh water fish. [documento on line] 2004. Disponivel em: <URL:http://www.sciencedirect.com> [2004 out 12].

Hickman-Brenner FW, Fanning GR, Arduino MJ, Brenner DJ, Farmer III JJ. Aeromonas schubertii, a new manitol-negative species found in human clinical specimens. J Clin Microbiol 1988; 26 (8): 1561-4.

Hickman-Brenner FW, Mac Donald KL, Steigerwalt AG, Fanning GR, Brenner DJ, Farmer III JJ. A. veronii a new ornithine descarboxilase positive species that may cause diarrhea. J Clin Microbiol 1987; 25 (5): 900-6.

Holmes P, Niccolls LM, Sartory DP. The ecology of mesophilic Aeromonas in the aquatic environent. In: Austin B, Altwegg M, Gosling PJ e Joseph S editors The genus Aeromonas. England; 1996. p. 127-50.

Houston CW, Chopra AK, Rose JM, Kurosky A. Review of Aeromonas enterotoxins. Experientia 1991; 47: 424-9.

Huys G, Kampfer P, Altwegg M, Kersters I, Lamb A, Coopman R et al. Aeromonas popoffii sp. Nov., a mesophilic bacterium isolated from drinking water production plants and reservoirs. Int J Syst Bacteriol 1997; 47 (4): 1165-71. 
Huys $G$, Pearson $M$, Kämpfer $P$, Denys $R$, Cnockaert $M$, Inglis $V$ et al. Aeromonas hydrophila subsp. ranae subsp. nov., isolated from septicaemic farmed frogs in Thailand. Int J Syst Evol Microbiol 2003; 53: 885-891.

Inglis V, Yimer E, Bacon EJ, Ferguson S. Plasmid-mediated antibiotic resistance in Aeromonas salmonicida isolated from Atlantic salmon, Salmo salar L, in Scotland. J Fish Dis 1993; 16: 593-599.

Isonhood JH, Drake M. Aeromonas species in foods. J Food Prot 2002; 65: (3): 575-582.

Janda JM, Abbott SL, Khashe S, Kellogg GH, Shinada T. Further studies on biochemical characteristics and serologic properties of the genus Aeromonas. J Clin Microbiol 1996; 34: 1930-3.

Jayaram M, Mehta S, Uzri D, Velmurugan S. Segregation of the yeast plasmid: similarities and contrasts with bacterial plasmid partitioning. Plasmid 2004; 51: 162-178.

Jitrapakdee S, Tassanakajon A, Boonsaeng V, Piankijagum S, Panyim S. A simple, rapid and sensitive detection of salmonella in food by polymerase chain reaction. Mol Cell Probes 1995; 9: 375-382.

Joseph SW, Aeromonas gastrointestinal disease: a case study in causation? In: Austin B et al., editors The genus Aeromonas. London: Wiley. P; 1996. p. 311-335.

Joseph SW, Carnahan A. The isolation, identification, and systematics of the motile Aeromonas species. Ann Rev Fish Dis 1994; 4: 315-343.

Kaznowski A. Identification of Aeromonas strains of different origin to the genomic species level. J Appl Microbiol 1998; 84: 423-30.

Kelsey H, Porter DE, Scott G, Neet M, White D. Using geographic information system and regression analysis to evaluate relationships 
between land use and fecal coliform bacterial pollution. J Exp Mar Biol Ecol 2004; 298: 197-209.

Khalil MT, Hussein HA. Use of wastewater for aquaculture: an experimental field study at a sewage treatment plant, Egypt. Aqua Res 1997; 28: 859-865.

Khardori N e Fainstein V. Aeromonas and Plesiomonas as etiological agents. Ann Rev Microbiol 1988; 42: 395-419.

Kirov SM, O"Donovan LA, Sanderson K. Functional characterization of type IV pili expressed on diarrea-associated isolates of Aeromonas species. Infect Immunol 1999; 67: 5447-54.

Kirov SM. Aeromonas and Plesiomonas species. In: Doyle MP et al., editors. Food microbiology, fundamentals and frontiers v1. Washington: ASM Press; 1997. p. 265-87.

Kirov SM. The public health significance of Aeromonas spp in foods. Int $\mathbf{J}$ Food Microbiol 1993; 20: 179-98.

Kitamura PC, Lopes RB, Castro Jr, de Queiros JF. Avaliação ambiental e econômica dos lagos de pesca esportiva na bacia do Rio Piracicaba. Bol Industr Animal 1999; 56(1): 95-107.

Kokka RP, Lindquist D, Aboott SL, Janda JM. Structural and pathogenic properties of Aeromonas schubertii. Infect Immunol 1992; 60 (5): 20752085.

Kolar CS, Lodge DM. Progress in invasion biology: predicting invaders. Trends Ecol Evol 2001; 16 (4): 199-204.

Koneman EW, Allen SD, Janda WM, Schreckenberger PC, Winn Jr WC. Diagnóstico microbiológico - texto e atlas colorido $5^{\mathrm{a}}$ ed. Brasil: MEDSI 2001. 
Lalumera GM, Calamari D, Galli P, Castiglioni S, Crosa G, Fanelli R. Preliminary investigation on the environmental occurrence and effects of antibiotics used in aquaculture in Italy. Chemosphere 2004; 54: 661-668.

Lima MG, Reis RB. Incidência de Salmonella spp. Comparação entre metodologias de detecção em amostras de pacu (Piaractus mesopotamicus) de rio de cultivado comercializadas no município de Cuiabá - MT. Higiene Alimentar 2002; 16 (101): 43-49.

Linder CE, Nogueira-Pinto JPA, Roça RO. Salmonella sp em sistemas intensivos de criação de peixes tropicais de água doce [Apresentado ao $\mathrm{XX}$ Congresso Brasileiro de Microbiologia, 1999 out 24-28; Salvador, Bahia, Brasil].

Liuson E. Pesquisa de coliformes totais, fecais e Salmonella spp em tilápias de pesqueiros da região metropolitana de São Paulo. São PauloSP; 2003. [Dissertação de Mestrado-Faculdade de Medicina Veterinária da USP].

Lovshin LL. Tilapia culture in Brazil. In: Costa-Pierce e Rakocu JE, editors. Tilapia aquaculture in the américas v2. $1 \mathrm{ed}$. Louisiana: The World Aquaculture Society, 2000. p. 133-140.

Mara D, Cairncross S. Guidelines for the safe use of wastewater and excreta in agriculture and aquaculture: measures for public health protection. World Health Organization, Geneva.

Markoová R, Jeek J. Indicator bacteria and limnological parameters in fish ponds. Wat Res 1994; (28): 2477-2485.

Martinez-Murcia AJ, Esteves C, Garay E, Collins MD. Aeromonas allosaccharophilla sp. nov., a new mesophilic member of the genus Aeromonas. FEMS Microbiol Lett 1992; 91: 199-206. 
Martins ML, Rosabel FM, Yano, T. Incidence of toxic Aeromonas isolated from food and human infection. FEMS Immunol Med Microbiol 2002; 32 : 237-242.

Martins MT. Salmonella no ambiente aquático: significado sanitário. São Paulo-SP; 1979. [Tese de doutorado - Instituto de Ciências Biomédicas da USP].

Matté MH, Matté GR, Gil AI, Lanata CF, Huq A; Colwell RR. Molecular epidemiology of Aeromonas arequipa isolated from diarrhea in Arequipa Perú. [Apresentado ao $9^{\text {th }}$ International Simposyum on Aeromonas/Plesiomonas, 1999 maio 28-29; Chicago, Illinois, USA].

Matté MH, Nitrini, SMOO, Matté GR. Aeromonas relacionadas com infecções no homem: aspectos epidemiológicos, ecológicos, laboratoriais, de virulência e relativos à saúde pública. Laes \& Haes 1996; 104: 62-74.

Matté MH. Pesquisa de Aeromonas spp. potencialmente patogênicas em alguns pontos da represa de Guarapiranga destinados à recreação e captação para abastecimento público, São Paulo, SP. São Paulo-SP; 1995. [Dissertação de Mestrado-Faculdade de Saúde Pública da USP].

Menon P, Billen G, Servais P. Mortality rates of autochthonous and fecal bacteria in natural aquatic ecosystems. Wat Res 2003; 37: 4151-4158.

Mercante CTJ, Cabianca MA, Silva D, Costa SV, Esteves KE. Water quality in fee-fishing ponds located in the São Paulo metropolitan region, Brazil: analysis of the eutrophication process. Acta Lim Bras 2004; 16. In press.

Merino S, Rubire S, Knochel S, Tomás JM. Emerging pathogens: Aeromonas spp. Int J Food Microbiol 1995; 28: 157-168.

Messi P, Guerrieri E, Bondi M. Survival of an Aeromonas hydrophila in an artificial mineral water microcosm. Wat Res 2002; 36: 3410-3415. 
Michel C, Keroualt B, Martin C. Chloramphenicol and florfenicol susceptibility of fish pathogenic bacteria isolated in France: comparison of minimum inhibitory concentration, using recommended provisory standards for fish bacteria. J Appl Microbiol 2003; 95: 1008-1015.

Miñana-Galbis D, Farfán M, Fusté MC, Lorén JG. Aeromonas moluscorum sp nov. Isolated from bivalve molluscs. [documento on line] 2004. Available from: <URL:http://dx.doi.org/10.1099/ijs.0.63202-0> [2004 jun 15].

Nayduch D, Honko A, Noblet GP, Stutzenberger F. Detection of Aeromonas caviae in the common housefly Musca domestica by culture and polymerase chain reaction. Epidemiol Infect 2001; 127: 561-566.

Neill M. Microbiological indices for total coliform and $E$. coli bacteria in estuarine waters. Mar Pollut Bull [periódico on line] 2004. Availiable from: <URL: Http://www.sciencedirect .com> [2004 Out 21].

Noble RT, Moore DF, Leecaster MK, Mcgee CD, Weisberg. Comparison of total coliform, fecal coliform, and enterococcus bacterial indicator response for ocean recreational water quality testing. Wat Res 2003; 37: 1637-1643.

Ogawa M, Maia EL. Manual de pesca, ciência e tecnologia do pescado. Ceará: Loyola; 1999.

Ogbondeminu FS, Okoye FC. Microbiological evaluation of an untreated domestic wastewater aquaculture system. J Aqua Trop 1992; 7: 27-34.

Pal D, Das Gupta C. Microbial pollution in water and its effect on fish. J Aqua Anim Health 1992; 4: 32-39.

Palumbo AS, Maxino F, Williams AC, Buchanan RL, Thayer DW. StarchAmpicillin Agar for the quantitative detection of Aeromonas hydrophila. Appl Environm Microbiol 1985; 50 (4): 1027-30. 
Pessoa GVA e Peixoto ES. Caldo Selenito Novobiocina. Um meio de maior seletividade para o isolamento de Salmonella nas fezes. Rev Adolfo Lutz $1971 ; 31: 1-3$.

Pessoa GVA, Silva EAM. Meios de rugai e lisina - motilidade combinados em um só tubo para identificação presuntiva de enterobactérias. Rev Adolfo Lutz $1972 ; 32: 97-100$.

Pianetti A, Baffone W, Bruscolini F, Barbieri E, Biffi MR, Salvaggio $L$ et al. Presence of several pathogenic bacteria in the metauro and foglia rivers (Pesaro-Urbino, Italy). Wat Res 1998; 32 (5): 1515-1521.

Pianetti A, Sabatini L, Bruscolini F, Chiaverini F, Cecchetti G. Faecal contamination indicators, salmonella, vibrio and aeromonas in water used for the irrigation of agricultural products. Epidemiol Infect 2004; 132: 231-238.

Pickup RW, Rhodes G, Hermon-Taylor J. Monitoring bacterial pathogens in the environment: advantages of a multilayered approach. Curr Opinion Biotechnol 2003; 14: 319-325.

Pidiyar V, Kasnowski A, Narayan NB, Patole M, Shouche YS. Aeromonas culicicola sp. nov., from the midgut of Culex quinquefasciatus. Int J Syst Evol Microbiol 2002; 52: 1723-1728.

Pimentel LPS. Características físico-químicas e microbiológicas do gelo utilizado na conservação de pescado comercializado em supermercados da grande São Paulo, Brasil. São Paulo-SP; 2000 [Dissertação de Mestrado-Faculdade de Saúde Pública da USP].

Polo F, Figueras MJ, Inza I, Sala J, Fleisher JM, Guarro. Relationship between presence of Salmonella and indicators of faecal pollution in aquatic habitats. FEMS Microbiol Lett 1998; 160: 253-256.

Polprasert $\mathrm{C}$, Udom S, Choudry $\mathrm{KH}$. Septage disposal in waste recycling ponds. Wat Res 1984; 18: 519-528. 
Popoff MY, Bockemühl J, Gheesling LL. Supplement 2001 (no. 45) to the Kauffmann-White scheme. Res Microbiol 2003; 154: 173-174.

Popoff, M. Aeromonas In: Murray RGE e col., editors. Bergey's Manual of Systematic Bacteriology v. 1. Baltmore/ London: Willians \& Wilkins. 1984. p. $545-8$.

Radu S, Ahmad N, Ling FH, Reezal A. Prevalence and resistance to antibiotics for Aeromonas species from retail fish in Malaysia. Int $\mathbf{J}$ Food Microbiol 2003; 81: 261-266.

Rall VLM, laria ST, Heidtmann S; Pimenta FC, Gamba RC, Pedroso DMM. Aeromonas species isolated from pintado fish (Pseudoplatystoma sp): virulence factors and drug susceptibility. Rev Microbiol 1998; 29 (3): 222227.

Ralph H, Schubert W e Hegazi M. Aeromonas eucrenophila species nova. Aeromonas caviae a Later and Illgilimata Synonym of Aeromonas punctata. Zbl Backt Hyg 1988; 268: 34-9.

Razzolini MTP. Pesquisa de Aeromonas e suas toxinas em águas de consumo humano provenientes de caixa d'água e bebedouros. São Paulo-SP. 1998. [Dissertação de Mestrado - Universidade Mackenzie].

Ribeiro MAG, Kubo E, Mainardes-Pinto CSR. Efeito do adubo orgânico e da dosagem do fertilizante químico no aumento do fitoplâncton $e$ do zooplâncton. B Inst Pesca 1997; 24: 57-64

Rivera ING, Martins, MT. Bactérias enteropatogênicas no ambiente aquático. Rev Cienc Farm 1996; 17: 115-136.

Rocha SM. Estudo da ocorrência do gênero Aeromonas em sistemas de tratamento de esgotos por lagoas de estabilização no Município de Lins -SP. São Paulo-SP; 2004. [Tese de Doutorado-Faculdade de Saúde Pública da USP]. 
Rodhes G, Huys G, Swings J, McGann P, Hiney M, Smih P et al. Distribution of oxytetraciclin resistance plasmids between aeromonads in hospital and aquaculture environments: implication of $\operatorname{Tn} 1721$ in dissemination of the tetracyclin resistance determinant Tet A. Appl Environ Microbiol 2000; 66 (9): 3883-3890.

Schubert RHW. Genus II. Aeromonas. In: Krieg NR et al., editors. Bergey's Manual of Systematic Bacteriology. Baltimore: Williams \& Wilkins. 1974; 1 : $345-8$

Schubert RW, Hegazi M. Aeromonas eucrenophila species nov Aeromonas caviae a latter and illegitimate synonym of Aeromonas punctata. Zbl Bakt Hyg 1988; 268: 34-39.

Scoglio ME, Di Pietro A, Delia S, Mauro A, Lagana P. Virulence factor in vibrios and aeromonads isolated from seafoods. Microbiol 2001;24: 273280.

Seepersadsingh N, Adesiyun AA. Prevalence and antimicrobial resistance of Salmonella spp in pet mammals reptiles, fish aquarium water and birds in Trinidad. J Vet Med B 2003; 50: 488-493.

Senanayake SN, Ferson MJ, Botham SJ, Belinfante RT. A child with Salmonella enterica serotype Paratyphi B infection acquired from a fish tank. MJA 2004; 180: 250.

Shao J-Z, Liu J, Xiang L-X. Aeromonas hydrophila induces apoptosis in Carassius auratus lymphocytes in vitro. Aquaculture 2004; 229: 11-23.

Shereif MM, Easa M El-S, El-Samra MI, Mancy KH. A demonstration of wastewater treatment for reuse applications in fish production and irrigation in Suez, Egypt. Wat Sci Tech 1995; 32 (11): 137-144.

Soler L, Figueras MJ, Chacón MR, Vila J, Marco F, Murcia-Martinez AJ, Guarro J. Potencial virulence and antimicrobial susceptibility of Aeromonas 
popoffii recovered from freswater and seawater. FEMS Immunol Med Microbiol 2002; 32: 243-247.

Son R, Rusul G, Sahilah AM, Zainuri A, Raha AR, Salmah I. Antibiotic resistance and plasmid profile of Aeromonas hydrophila isolates from cultured fish, Telapia (Telapia mossambica). Lett Appl Microbiol 1997; 24: 479-482.

Soriano JM, Bico H, Moltó JC, Mañes J. Assessment of the microbiological quality and wash treatments of lettuce served in university restaurants. Int $\mathbf{J}$ Food Microbiol 2000; 58: 123-8.

Sorum H, L'Abée-Lund. Antibiotic resistance in food-related bacteria a result of interfering with the global web of bacterial genetics. Int J Food Microbiol 2002; 78: 43-56.

Soumet C, Ermel G, Rose N, Rose V, Drouin P, Salvat G, Colin P. Evaluation of a Multiplex PCR assay for simultaneous identification of Salmonella sp., Salmonella Enteritidis and Salmonella Typhimurium from environmental swabs of poultry houses. Lett Appl Microbiol 1999; 28: 113-117.

Steen $P$ van der, Brenner A, Shabtai $Y$, Oron G. Improved fecal coliform decay in integrated duckweed and algal ponds. Wat Sci Tech 2000; 42 (10): 33-370.

Toze S. PCR and the detection of microbial pathogens in water and wastewater. Wat Res 1999; 33 (17): 3545-3556.

Urriza GM, Pineau L, Capdepuy M, Roques C, Caumette P, Quentin C. Antimicrobial resistance of mesophilic Aeromonas spp. isolated from two European rives. J Antim Chemoth 2000; 46, 297-301.

Uyttendaele $M$, Neyts $K$, Vanderswalmen $H$, Notebaert $E$, Debevere J. Control of Aeromonas on minimally processed vegetables by decontamination with lactic acid, chlorinated water, or thyme essential oil solution. Int J Food Microbiol 2004; 90: 263-271. 
Vassiliadis $P$. The Rappaport-Vassiliadis (RV) enrichment medium for the isolation of Salmonellas: an overview. J Appl Bacteriol 1983; 54: 69-76.

Venturieri R. Pesque-Pague no Estado de São Paulo, vetor de desenvolvimento da piscicultura e opção de turismo e lazer. São Paulo: ECO Associação para Estudos do Ambiente; 2002. p. 11.

Vieira RHSF, Souza OV, Patel TR. Bacteriological quality of ice used in Mucuripe Market, Fortaleza, Brazil. Food Control 1997, 8 (2): 83-85.

Vila J, Ruiz J, Gallardo F, Vargas M, Soler L, Figueras MJ, Gascon J. Aeromonas spp and Traveler's Diarrhea: Clinical features and antimicrobial resistance. Emerging Infectious Diseases. 2003; 9 (5): 552-555.

Vivekanandhan G, Savithamani K, Hatha AAM, Lakshmanaperumalsamy P. Antibiotic resistance of Aeromonas hydrophila isolated from marketed fish and prawn of South India. Int J Food Microbiol. 2002; 76: 165-168.

Vivekanandhan G, Savithamani K, Lakshmanaperumalsamy P. Influence of $\mathrm{pH}$, salt concentration and temperature on the growth of Aeromonas hydrophila. J Environ Biol 2003; 24 (4): 373-379.

Warren WJ, Jeter RM, Kimbrough RC, Zak JC. Population patterns and antimicrobial resistance of Aeromonas in urban playa lakes. Can J Microbiol 2004; 50: 397-404.

Webster LF, Thompson BC, Fulton MH, Chestnut DE, Dolah RFV, Leight AK et al. Identification of sources of Escherichia coli in South Carolina estuaries using antibiotic resistance analysis. J Exp Mar Biol Ecol 2004; 298: 179195.

World Health Organization. Health guidelines for the use of wastewater in agriculture and aquaculture. Report. Geneva; 1989. (WHO - Technical Report Series, 778). 
Yan SS, Pendrak ML, Abela-Ridder B, Punderson JW, Fedorko DP, Foley SL. An overview of Salmonella typing public health perspectives. Clin Appl Immunol Rev 2003; 4: 189-204. 


\section{GLOSSÁRIO}

Aloctone: organismo que não pertence, originalmente, ao habitat em que se encontra no momento.

Bacteremia: condição em que há bactérias no sangue.

Bactéria entérica: nome comum para bactérias da familia Enterobacteriaceae, que habita o trato intestinal de seres humanos e outros animais.

Bactérias gram-negativas: bactérias que perdem a cor da violeta de genciana após serem descoradas pelo álcool, permanecendo o rosa após tratamento com safranina, devido as características de sua parede celular.

Bergey's Manual: referência taxonômica padrão das bactérias.

Beta-hemólise: produção de uma zona clara ao redor das colônias em conseqüência do efeito da lise total das hemácias.

Biofilme: comunidade microbiana que usualmente se forma como uma camada de lodo em uma superficie.

Biologia molecular: ciência que trata da sintese e caracterização de DNA e proteínas pelos organismos vivos.

Cepa: grupo de células derivado de uma única célula.

Coliformes: bacilos gram-negativos aeróbicos ou anaeróbicos facultativos, formadores de endósporos, que fermentam a lactose com formação de ácido e gás em 48 horas a $35^{\circ} \mathrm{C}$; são usados como organismo indicador para testes de pureza bacteriológica.

Colônia: clone de células bacterianas em um meio sólido, que é visível a olho nu.

Cultura de enriquecimento: cultura obtida em meio de cultura usado para o isolamento preliminar, que favorece o crescimento de um microrganismo em particular.

Denaturação ou desnaturação: alteração drástica na conformação de uma proteina ou ácido nucléico pelo calor ou tratamento químico, resultando em perda da função biológica. 
DNA: polinucleotídio de fita dupla, formado a partir de duas cadeias separadas de unidades de desoxirribonucleotideos; carreador da informação genética.

Enterotoxina: exotoxina que causa gastroenterite.

Enzima hemolítica: enzimas que lisam os eritrócitos.

Enzimas proteoliticas: enzimas que agem sobre as proteinas.

Eutrófico: corpo d'água caracterizado por altas concentraçōes de nutrientes e alta produtividade.

Infecção: invasão ou proliferação de microrganismos no corpo.

kb: kilo base.

Lise: destruição de uma célula pela ruptura da membrana plasmática.

Meio seletivo: meio de cultura designado para suprimir o crescimento de microrganismos indesejados e favorecer o crescimento daqueles desejados.

Mesófilo: bactéria que cresce preferencialmente em uma faixa de temperatura entre $25^{\circ} \mathrm{C}$ e $40^{\circ} \mathrm{C}$.

Método do número mais provável (NMP): determinação estatistica do número de coliformes por $100 \mathrm{~mL}$ de água ou $100 \mathrm{~g}$ de alimento.

Patogenicidade: capacidade de um microrganismo de causar doença superando as defesas do hospedeiro.

Patógeno emergente: microrganismo desconhecido, alterado ou conhecido, mas que não estava em evidência, que estejam envolvidos com o aumento de casos de determinada doença em uma população.

Patógeno oportunista: microrganismo que normalmente não causa doença, mas que pode se tornar patogênico sob certas circunstâncias

Patógeno: organismo causador de doença.

Peso molecular: soma dos pesos atômicos de todos os átomos que compõem uma molécula.

Plasmidio: pequena molécula circular de DNA que pode estar presente em bactérias, que se replica independentemente do cromossomo.

Polimerase: termo geral para designar uma enzima que catalisa a adição de subunidades a um polímero, por exemplo, a DNA polimerase sintetiza DNA. 
Primer de RNA: fita curta de RNA, usada para iniciar a síntese da fita intermediária de DNA, e para iniciar a reação da cadeia de polimerase.

Reação em cadeia da polimerase (PCR): técnica utilizando a DNA polimerase para fazer múltiplas cópias de um molde de DNA in vitro.

Resultado falso-positivo: reação de positividade (aglutinação) entre a bactéria alvo e o anti-soro específico, mas que, na realidade, não corresponde à espécie ou gênero pesquisado.

Septicemia:proliferação de bactérias no sangue, acompanhada de febre; algumas vezes causa lesão de órgãos.

Sorologia: ramo da imunologia que estuda as reaçōes antígeno-anticorpo.

Sorotipo: variação dentro de uma espécie; também chamado sorovar

Taxonomia: ciência que estuda a classificação dos organismos.

Testes sorológicos: técnicas para identificação de grupos de microrganismos com base reação a anticorpos especificos.

Virulência: grau de patogenicidade de um microrganismo. 
ANEXOS 


\section{Anexo I}

\section{Aeromonas hydrophila}

\begin{tabular}{|c|c|c|c|c|}
\hline Amostra & Periodo & No de plasmidios & Peso molecular (kb) & $\mathbf{N}^{\circ}$ da Cepa \\
\hline A & $\mathrm{CH}$ & 0 & & 486 \\
\hline A & $\mathrm{CH}$ & 0 & & 514 \\
\hline A & $\mathrm{CH}$ & 0 & & 515 \\
\hline A & $\mathrm{CH}$ & 0 & & 577 \\
\hline A & $\mathrm{CH}$ & 1 & 80 & 604 \\
\hline A & $\mathrm{CH}$ & 2 & $80 ; 23,1$ & 498 \\
\hline A & $\mathrm{CH}$ & 2 & $33 ; 16,2$ & 432 \\
\hline A & $\mathrm{CH}$ & 2 & 5,$5 ; 3,3$ & 663 \\
\hline A & SE & 3 & $33 ; 16,2 ; 6,5$ & 140 \\
\hline A & $\mathrm{CH}$ & 7 & $80 ; 53 ; 23,1 ; 16,2 ; 3,8 ; 3,3 ; 2,3$ & 511 \\
\hline $\mathbf{P}$ & SE & 1 & 16,2 & $3 A$ \\
\hline $\mathbf{P}$ & SE & 1 & 80 & 50 \\
\hline $\mathbf{P}$ & SE & 2 & $80 ; 23,1$ & 3B \\
\hline $\mathbf{P}$ & $\mathrm{CH}$ & 2 & $33 ; 16,2$ & 463 \\
\hline $\mathbf{P}$ & SE & 3 & $80 ; 43 ; 23,1$ & 4 \\
\hline $\mathbf{P}$ & SE & 3 & $80 ; 43 ; 23,1$ & $7 A$ \\
\hline $\mathbf{P}$ & SE & 3 & $80 ; 43 ; 23,1$ & 78 \\
\hline $\mathbf{P}$ & SE & 4 & $80 ; 43 ; 23,1 ; 9,4$ & $8 A$ \\
\hline
\end{tabular}

Nota: $A=a ́ g u a ; P=$ peixe; $C H=$ período chuvoso; $S E=$ periodo seco

\section{Aeromonas popofiii}

\begin{tabular}{ccccc} 
Amostra & Período & $N^{0}$ de plasmidios & Peso molecular $(\mathbf{k b})$ & $\mathbf{N}^{\mathbf{0}}$ da cepa \\
\hline $\mathrm{A}$ & $\mathrm{CH}$ & 0 & & 565 \\
$\mathrm{~A}$ & $\mathrm{CH}$ & 1 & 80 & 735 \\
$\mathrm{~A}$ & $\mathrm{SE}$ & 6 & $80 ; 33 ; 23,1 ; 9,4 ; 6,5 ; 4,4$ & 52 \\
\hline
\end{tabular}

Nota: $\mathrm{A}=a$ gua; $\mathrm{P}=$ =peixe; $\mathrm{CH}=$ período chuvoso; $\mathrm{SE}=$ período seco 


\section{Anexo II}

\section{Aeromonas jandaei}

\begin{tabular}{|c|c|c|c|c|}
\hline Amostra & Período & $\begin{array}{c}N^{\circ} \text { de } \\
\text { plasmidios }\end{array}$ & Peso molecular (kb) & $\begin{array}{c}N^{N} \\
\text { da copa }\end{array}$ \\
\hline A & $\mathrm{SE}$ & 0 & & 7 \\
\hline A & SE & 0 & & 9 \\
\hline A & $\mathrm{SE}$ & 0 & & 16 \\
\hline A & SE & 0 & & 30 \\
\hline A & SE & 0 & & 34 \\
\hline A & SE & 0 & & 67 \\
\hline A & SE & 0 & & 83B \\
\hline A & SE & 0 & & $85 \mathrm{~A}$ \\
\hline A & SE & 0 & & 90 \\
\hline A & SE & 0 & & 95 \\
\hline A & SE & 0 & & 103 \\
\hline A & SE & 0 & & 129 \\
\hline A & SE & 0 & & 130 \\
\hline A & SE & 0 & & 149 \\
\hline A & $\mathrm{SE}$ & 0 & & 150 \\
\hline A & SE & 0 & & 156 \\
\hline A & SE & 0 & & 178 \\
\hline A & SE & 0 & & 181 \\
\hline A & SE & 0 & & 209 \\
\hline A & SE & 0 & & 211 \\
\hline A & SE & 0 & & 215 \\
\hline A & SE & 0 & & 220 \\
\hline A & SE & 0 & & $278 B$ \\
\hline A & SE & 0 & & 281 \\
\hline A & SE & 1 & 23,1 & 12 \\
\hline$A$ & $\mathrm{SE}$ & 1 & 23,1 & 19 \\
\hline A & SE & 1 & 80 & 55 \\
\hline A & SE & 1 & 80 & 58 \\
\hline A & SE & 1 & 80 & 61 \\
\hline A & SE & 1 & 80 & $153 B$ \\
\hline A & SE & 1 & 80 & 227 \\
\hline A & SE & 1 & 1,6 & 242 \\
\hline A & SE & 1 & 23,1 & 293 \\
\hline A & SE & 1 & 23,1 & 297 \\
\hline A & $\mathrm{SE}$ & 2 & $33 ; 23,1$ & 5 \\
\hline A & SE & 2 & $80 ; 23,1$ & 13 \\
\hline A & SE & 2 & $33 ; 23,1$ & 46 \\
\hline A & $\mathrm{SE}$ & 2 & $80 ; 23,1$ & 154 \\
\hline A & SE & 3 & $33 ; 23,1 ; 3,3$ & 11 \\
\hline A & $\mathrm{SE}$ & 3 & $80 ; 33 ; 23,1$ & 62 \\
\hline A & SE & 3 & 3,$8 ; 2,8 ; 2,0$ & 100 \\
\hline A & SE & 3 & 9,$4 ; 4,4 ; 3,3$ & 188 \\
\hline A & SE & 3 & 6,$5 ; 4,1 ; 3,0$ & 213 \\
\hline
\end{tabular}




\section{Continuação}

\section{Aeromonas jandaei}

\begin{tabular}{|c|c|c|c|c|}
\hline Amostra & Periodo & $\begin{array}{l}\text { No de } \\
\text { plasmidios }\end{array}$ & Peso molecular (kb) & $\begin{array}{c}N^{\circ} \\
\text { da cepa }\end{array}$ \\
\hline A & SE & 3 & 3,$3 ; 2,8 ; 2,3$ & 228 \\
\hline A & SE & 3 & 4,$3 ; 3,3 ; 2,3$ & 334 \\
\hline A & SE & 4 & 23,$1 ; 6,5 ; 5,5 ; 4,4$ & $101 \mathrm{~B}$ \\
\hline A & SE & 4 & 23,$1 ; 6,5 ; 4,4 ; 4,1$ & $168 \mathrm{~B}$ \\
\hline A & SE & 4 & 23,$1 ; 6,5 ; 4,4 ; 4,1$ & 170 \\
\hline A & SE & 4 & 23,$1 ; 6,5 ; 4,4 ; 4,1$ & 171 \\
\hline A & SE & 4 & 23,$1 ; 16,2 ; 1,6 ; 1,3$ & 233 \\
\hline A & SE & 4 & 23,$1 ; 6,5 ; 4,3 ; 3,0$ & 290 \\
\hline A & SE & 8 & 23,$1 ; 6,4 ; 4,4 ; 3,3 ; 2,8 ; 2,0 ; 1,6 ; 1,0$ & 51 \\
\hline A & SE & 8 & 23,$1 ; 8,0 ; 6,5 ; 5,8 ; 4,4 ; 4,1 ; 3,3 ; 3,0$ & 175 \\
\hline A & SE & 8 & 23,$1 ; 8,0 ; 6,5 ; 5,8 ; 4,4 ; 4,1 ; 3,3 ; 3,0$ & 176 \\
\hline A & SE & 8 & 23,$1 ; 8,0 ; 6,5 ; 5,8 ; 4,4 ; 4,1 ; 3,3 ; 3,0$ & 177 \\
\hline A & SE & 8 & 23,$1 ; 16,2 ; 6,5 ; 5,5 ; 4,4 ; 4,1 ; 3,3 ; 3,0$ & 194 \\
\hline A & SE & 9 & $80 ; 23,1 ; 16,2 ; 6,5 ; 5.5 ; 4,4 ; 4,1 ; 3,3 ; 3.0$ & 192 \\
\hline A & SE & 9 & $80 ; 23,1 ; 16,2 ; 6,5 ; 5,5 ; 4,4 ; 3,3 ; 2,3 ; 1,3$ & 193 \\
\hline A & SE & 9 & $33 ; 23,1 ; 16,2 ; 6,5 ; 5,5 ; 4,4 ; 3,3 ; 2,3 ; 1,3$ & 195B \\
\hline A & SE & 10 & $80 ; 23,1 ; 16,2 ; 6,5 ; 4,4 ; 4,1 ; 3,8 ; 3,3 ; 2,0 ; 1,3$ & 187 \\
\hline A & SE & 13 & $\begin{array}{c}33 ; 23,1 ; 16,2 ; 6,5 ; 5,5 ; 5,1 ; 4,4 ; 4,1 ; 3,3 ; 3,0 ; \\
2,3 ; 2,0 ; 1,3\end{array}$ & 196 \\
\hline A & $\mathrm{CH}$ & 0 & & 345 \\
\hline A & $\mathrm{CH}$ & 0 & & 424 \\
\hline A & $\mathrm{CH}$ & 0 & & 455 \\
\hline A & $\mathrm{CH}$ & 0 & & 536 \\
\hline A & $\mathrm{CH}$ & 0 & & 539 \\
\hline A & $\mathrm{CH}$ & 0 & & 540 \\
\hline A & $\mathrm{CH}$ & 0 & & 544 \\
\hline A & $\mathrm{CH}$ & 0 & & 552 \\
\hline A & $\mathrm{CH}$ & 0 & & 599 \\
\hline A & $\mathrm{CH}$ & 0 & & 606 \\
\hline A & $\mathrm{CH}$ & 0 & & 617 \\
\hline A & $\mathrm{CH}$ & 0 & & 626 \\
\hline A & $\mathrm{CH}$ & 0 & & 629 \\
\hline$A$ & $\mathrm{CH}$ & 0 & & 664 \\
\hline A & $\mathrm{CH}$ & 1 & 80 & 499 \\
\hline A & $\mathrm{CH}$ & 1 & 2,3 & 602 \\
\hline A & $\mathrm{CH}$ & 3 & $33 ; 23,1 ; 6,5$ & 428 \\
\hline A & $\mathrm{CH}$ & 3 & 23,$1 ; 4,4 ; 4,1$ & 527 \\
\hline A & $\mathrm{CH}$ & 8 & $80 ; 23,1 ; 16,2 ; 9,4 ; 6,5 ; 5,5 ; 4,4 ; 3,3$ & 363 \\
\hline A & $\mathrm{CH}$ & 8 & $80 ; 23,1 ; 16,2 ; 9,4 ; 6,5 ; 5,5 ; 4,4 ; 3,3$ & 380 \\
\hline $\mathbf{P}$ & SE & 0 & & 53 \\
\hline$P$ & SE & 0 & & 105 \\
\hline$P$ & SE & 1 & 80 & 140 \\
\hline $\mathbf{P}$ & SE & 1 & 80 & 151 \\
\hline
\end{tabular}




\section{Continuação}

\section{Aeromonas jandaei}

\begin{tabular}{|c|c|c|c|c|}
\hline Amostra & Periodo & $\begin{array}{c}N^{\circ} \text { de } \\
\text { plasmídios }\end{array}$ & Peso molecular (kb) & $\begin{array}{c}N^{\circ} \\
\text { da cepa }\end{array}$ \\
\hline $\mathbf{P}$ & $\mathrm{SE}$ & 1 & 80 & 146 \\
\hline $\mathbf{P}$ & SE & 1 & 33 & 210 \\
\hline $\mathbf{P}$ & SE & 1 & 80 & 243 \\
\hline $\mathbf{P}$ & SE & 2 & $33 ; 23,1$ & $17 \mathrm{~B}$ \\
\hline $\mathbf{P}$ & SE & 2 & $33 ; 23,1$ & 21 \\
\hline $\mathbf{P}$ & SE & 2 & $33 ; 23,3$ & 26 \\
\hline $\mathbf{P}$ & SE & 3 & $33 ; 23,1 ; 5,8$ & 219 \\
\hline $\mathbf{P}$ & SE & 3 & $80 ; 43 ; 23,1$ & $16 \mathrm{~A}$ \\
\hline $\mathbf{P}$ & SE & 4 & $33 ; 6,5 ; 5,5 ; 4,4$ & 233 \\
\hline $\mathbf{P}$ & SE & 4 & $33 ; 6,5 ; 5,5 ; 4,4$ & 237 \\
\hline $\mathbf{P}$ & SE & 7 & $80 ; 43 ; 23,1 ; 6,5 ; 3,3 ; 2,3 ; 2,0$ & $9 A$ \\
\hline $\mathbf{P}$ & SE & 7 & $80 ; 43 ; 23,1 ; 6,5 ; 3,3 ; 2,3 ; 2,0$ & $9 \mathrm{~B}$ \\
\hline $\mathbf{P}$ & SE & 7 & $80 ; 43 ; 23,1 ; 6,5 ; 3,3 ; 2,3 ; 2,0$ & $9 \mathrm{C}$ \\
\hline $\mathbf{P}$ & $\mathrm{CH}$ & 0 & & 281 \\
\hline $\mathbf{P}$ & $\mathrm{CH}$ & 0 & & 465 \\
\hline $\mathbf{P}$ & $\mathrm{CH}$ & 0 & & 486 \\
\hline $\mathbf{P}$ & $\mathrm{CH}$ & 0 & & 488 \\
\hline $\mathbf{P}$ & $\mathrm{CH}$ & 0 & & 496 \\
\hline $\mathbf{p}$ & $\mathrm{CH}$ & 0 & & 519 \\
\hline $\mathbf{P}$ & $\mathrm{CH}$ & 0 & & 547 \\
\hline $\mathbf{P}$ & $\mathrm{CH}$ & 0 & & 555 \\
\hline $\mathbf{P}$ & $\mathrm{CH}$ & 0 & & 603 \\
\hline $\mathbf{P}$ & $\mathrm{CH}$ & 1 & 80 & 347 \\
\hline $\mathbf{P}$ & $\mathrm{CH}$ & 1 & 80 & 587 \\
\hline $\mathbf{P}$ & $\mathrm{CH}$ & 1 & 5,5 & 606 \\
\hline $\mathbf{P}$ & $\mathrm{CH}$ & 2 & $33 ; 16,2$ & 325 \\
\hline $\mathbf{P}$ & $\mathrm{CH}$ & 2 & $80 ; 16,2$ & 594 \\
\hline $\mathbf{P}$ & $\mathrm{CH}$ & & $33 ; 23,1$ & 613 \\
\hline $\mathbf{P}$ & $\mathrm{CH}$ & 7 & 23,$1 ; 9,4 ; 5,5 ; 4,4 ; 3,3,2,8 ; 2,0$ & 467 \\
\hline
\end{tabular}

Nota: $A=a g u a ; P=$ peixe; $C H=$ periodo chuvoso; $S E=$ periodo $s e c o$ 


\section{Anexo III}

\section{Aeromonas trota}

\begin{tabular}{|c|c|c|c|c|}
\hline Amostra & Periodo & N do plasmidio & Peso molecular (kb) & $\boldsymbol{N}$ da copa \\
\hline$A$ & SE & 0 & & 4 \\
\hline A & SE & 0 & & 6 \\
\hline A & SE & 0 & & 24 \\
\hline A & SE & 0 & & 64 \\
\hline$A$ & SE & 0 & & 66 \\
\hline A & SE & 0 & & $83 \mathrm{~A}$ \\
\hline A & SE & 0 & & $85 B$ \\
\hline$A$ & SE & 0 & & $86 A$ \\
\hline A & SE & 0 & & $86 B$ \\
\hline A & SE & 0 & & 92 \\
\hline A & SE & 0 & & $101 \mathrm{~A}$ \\
\hline A & SE & 0 & & 117 \\
\hline A & SE & 0 & & 135 \\
\hline A & SE & 0 & & 141 \\
\hline A & SE & 0 & & 221 \\
\hline A & SE & 1 & 80 & 25 \\
\hline A & SE & 1 & 80 & 54 \\
\hline A & SE & 1 & 80 & 56 \\
\hline A & SE & 1 & 80 & 138 \\
\hline A & SE & 1 & 80 & 143 \\
\hline A & $S E$ & 1 & 80 & 147 \\
\hline A & SE & 1 & 80 & 152 \\
\hline A & SE & 1 & 80 & $153 \mathrm{~A}$ \\
\hline A & SE & 1 & 80 & 158 \\
\hline A & SE & 2 & $33 ; 23,1$ & 15 \\
\hline A & SE & 2 & $33 ; 23,1$ & 69 \\
\hline A & SE & 2 & 23,$1 ; 6,5$ & 217 \\
\hline A & SE & 3 & $80 ; 33 ; 23,1$ & 10 \\
\hline A & SE & 3 & $80 ; 33 ; 23,1$ & 57 \\
\hline A & SE & 3 & 23,$1 ; 5,5 ; 4,3$ & 99 \\
\hline A & SE & 3 & $80 ; 43 ; 9,4$ & 329 \\
\hline A & SE & 4 & $33 ; 23,1 ; 5,5 ; 3,8$ & 3 \\
\hline A & SE & 4 & 23,$1 ; 5,5 ; 4,3 ; 3,3$ & 14 \\
\hline A & SE & 4 & 23,$1 ; 6,5 ; 4,3 ; 3,3$ & 65 \\
\hline A & SE & 4 & 6,$5 ; 4,4 ; 2,8 ; 2,3$ & 88 \\
\hline A & SE & 4 & 23,$1 ; 6,5 ; 4,4 ; 4,1$ & 163 \\
\hline A & SE & 4 & 23,$1 ; 6,5 ; 4,4 ; 4,1$ & 167 \\
\hline A & SE & 5 & 23,$1 ; 16,2 ; 6,5 ; 5,5 ; 4,4$ & 102 \\
\hline A & SE & 5 & 23,$1 ; 16,2 ; 6,5 ; 5,5 ; 4,4$ & 104 \\
\hline A & SE & 5 & $80 ; 23,1 ; 5,5 ; 4,4 ; 4,1$ & 160 \\
\hline A & SE & 5 & $80 ; 23,1 ; 5,5 ; 4,4 ; 4,1$ & 161 \\
\hline A & SE & 6 & $43 ; 33 ; 23,1 ; 9,4 ; 6,5 ; 4.4$ & 50 \\
\hline A & SE & 6 & $80 ; 16,2 ; 6,5 ; 3,8 ; 3,3 ; 2,3$ & 191 \\
\hline A & SE & 7 & $80 ; 43 ; 23,1 ; 9,4 ; 6,5 ; 4,4 ; 3,3$ & 59 \\
\hline A & SE & 7 & 3,$8 ; 2,8 ; 2,3 ; 1,8 ; 1,6 ; 1,3$ & 93 \\
\hline
\end{tabular}




\section{Continuação}

\section{Aeromonas trota}

\begin{tabular}{|c|c|c|c|c|}
\hline Amostra & Periodo & N de plasmidio & Peso molecular (kb) & No da capa \\
\hline A & SE & 13 & $\begin{array}{l}33 ; 23,1 ; 16,2 ; 6,5 ; 5,5 ; 5,1 ; 4,4 ; 4,1 ; 3,3 ; 3,0 ; 2,3 \\
2,0 ; 1,3\end{array}$ & 197 \\
\hline A & $\mathrm{CH}$ & 0 & & 623 \\
\hline A & $\mathrm{CH}$ & 1 & 80 & 504 \\
\hline A & $\mathrm{CH}$ & 1 & 4,4 & 535 \\
\hline A & $\mathrm{CH}$ & 1 & 80 & 579 \\
\hline A & $\mathrm{CH}$ & 1 & 80 & 613 \\
\hline A & $\mathrm{CH}$ & 1 & 80 & 614 \\
\hline A & $\mathrm{CH}$ & 1 & 80 & 618 \\
\hline A & $\mathrm{CH}$ & 1 & 80 & 625 \\
\hline A & $\mathrm{CH}$ & 2 & $80 ; 23,1$ & 481 \\
\hline A & $\mathrm{CH}$ & 2 & $80 ; 23,1$ & 574 \\
\hline A & $\mathrm{CH}$ & 3 & $80 ; 33 ; 6,5$ & 437 \\
\hline$A$ & $\mathrm{CH}$ & 4 & $80 ; 4,4 ; 3,3 ; 2,8$ & 487 \\
\hline$P$ & SE & 0 & & 27 \\
\hline$P$ & SE & 0 & & 36 \\
\hline $\mathbf{P}$ & SE & 0 & & 38 \\
\hline $\mathbf{P}$ & SE & 0 & & 39 \\
\hline $\mathbf{P}$ & SE & 0 & & 49 \\
\hline $\mathbf{P}$ & SE & 0 & & 51 \\
\hline $\mathbf{P}$ & SE & 0 & & 54 \\
\hline $\mathbf{P}$ & SE & 0 & & 83 \\
\hline $\mathbf{P}$ & SE & 0 & & 161 \\
\hline$P$ & SE & 0 & & 163 \\
\hline$P$ & SE & 1 & 80 & 89 \\
\hline$P$ & SE & 1 & 80 & 41 \\
\hline$P$ & SE & 1 & 2,8 & 92 \\
\hline $\mathbf{P}$ & SE & 1 & 80 & 141 \\
\hline$P$ & SE & 1 & 80 & 145 \\
\hline $\mathbf{P}$ & SE & 1 & 80 & 200 \\
\hline$P$ & SE & 1 & 33 & 192 \\
\hline$P$ & SE & 2 & $33: 23,1$ & $2 A$ \\
\hline $\mathbf{P}$ & SE & 2 & $33 ; 23,1$ & $2 B$ \\
\hline$P$ & SE & 2 & $33 ; 23,1$ & 20 \\
\hline $\mathbf{P}$ & SE & 2 & $33 ; 23,1$ & 22 \\
\hline $\mathbf{P}$ & SE & 2 & $33 ; 23,1$ & 23 \\
\hline$P$ & SE & 2 & $33 ; 23,1$ & 25 \\
\hline$P$ & SE & 2 & 2,$0 ; 1,3$ & 195 \\
\hline$P$ & SE & 2 & $33 ; 23,1$ & 222 \\
\hline$P$ & SE & 3 & 4,$4 ; 3,3 ; 2,3$ & 48 \\
\hline $\mathbf{P}$ & SE & 3 & 9,$4 ; 4,4 ; 3,3$ & $78 B$ \\
\hline$P$ & SE & 3 & $80 ; 4,1 ; 3,8$ & 109 \\
\hline$P$ & SE & 3 & $80 ; 23,1 ; 5,8$ & 218 \\
\hline$P$ & SE & 3 & $33 ; 23,1 ; 5,8$ & 226 \\
\hline $\mathbf{P}$ & SE & 4 & 16,$2 ; 9,4 ; 6,5 ; 4,4$ & 32 \\
\hline
\end{tabular}




\section{Continuação}

\section{Aeromonas trota}

\begin{tabular}{|c|c|c|c|c|}
\hline Amostra & Periodo & N de plasmidio & Peso molecular (kb) & $\mathbf{N}$ da cepa \\
\hline $\mathbf{P}$ & SE & 4 & $33 ; 6,5 ; 5 ; 4,4$ & 224 \\
\hline $\mathbf{P}$ & SE & 5 & 16,$2 ; 9,4 ; 5,8 ; 4,4 ; 3,8$ & 43 \\
\hline $\mathbf{P}$ & SE & 5 & 16,$2 ; 9,4 ; 5,8 ; 4,4 ; 3,8$ & 44 \\
\hline $\mathbf{P}$ & SE & 7 & 16,$2 ; 9,4 ; 6,5 ; 5,8 ; 5,1 ; 4,4 ; 3,3$ & 37 \\
\hline $\mathbf{P}$ & SE & 9 & $80 ; 43 ; 633 ; 23,1 ; 9,4 ; 6,5 ; 2,3 ; 1,6 ; 1,3$ & $1 \mathrm{~A}$ \\
\hline $\mathbf{P}$ & SE & 9 & $80 ; 43 ; 633 ; 23,1 ; 9,4 ; 6,5 ; 2,3 ; 1,6 ; 1,3$ & 18 \\
\hline $\mathbf{P}$ & $\mathrm{CH}$ & 0 & & 346 \\
\hline $\mathbf{P}$ & $\mathrm{CH}$ & 1 & 33 & 289 \\
\hline $\mathbf{P}$ & $\mathrm{CH}$ & 1 & 23,1 & 328 \\
\hline $\mathbf{P}$ & $\mathrm{CH}$ & 1 & 80 & 560 \\
\hline$P$ & $\mathrm{CH}$ & 1 & 80 & 600 \\
\hline$P$ & $\mathrm{CH}$ & 1 & 80 & 601 \\
\hline $\mathbf{P}$ & $\mathrm{CH}$ & 1 & $\mathbf{3 , 3}$ & 610 \\
\hline$P$ & $\mathrm{CH}$ & 2 & 23,$1 ; 3,3$ & 345 \\
\hline$P$ & $\mathrm{CH}$ & 2 & $80 ; 23,1$ & 590 \\
\hline$P$ & $\mathrm{CH}$ & 3 & 9,$4 ; 3,3 ; 3,0$ & 283 \\
\hline$P$ & $\mathrm{CH}$ & 3 & $80 ; 23,1 ; 16,2$ & 593 \\
\hline $\mathbf{P}$ & $\mathrm{CH}$ & 3 & $80 ; 23,1 ; 16,2$ & 599 \\
\hline $\mathbf{P}$ & $\mathrm{CH}$ & 3 & $80 ; 23,1 ; 16,2$ & 602 \\
\hline$P$ & $\mathrm{CH}$ & 3 & 23,$1 ; 3,8 ; 1,6$ & 607 \\
\hline $\mathbf{p}$ & $\mathrm{CH}$ & 5 & $33 ; 5,5 ; 4,4 ; 2,8 ; 2,3$ & 278 \\
\hline
\end{tabular}

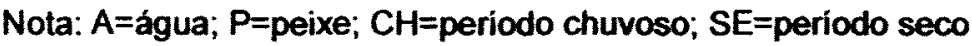




\section{Anexo IV}

\begin{tabular}{|c|c|c|c|c|}
\hline \multicolumn{5}{|c|}{ Aeromonas veronii sobria } \\
\hline Amostra & Período & $\begin{array}{c}\text { No de } \\
\text { plasmidios }\end{array}$ & Peso molecular (kb) & $\begin{array}{c}N^{\infty} \\
\text { da cepa }\end{array}$ \\
\hline A & SE & 0 & & 119 \\
\hline A & SE & 0 & & 122 \\
\hline A & SE & 0 & & 124 \\
\hline A & SE & 0 & & 127 \\
\hline A & SE & 0 & & 132 \\
\hline A & SE & 0 & & 137 \\
\hline A & $\mathrm{SE}$ & 0 & & 148 \\
\hline A & SE & 0 & & 162 \\
\hline A & SE & 0 & & 169 \\
\hline A & SE & 0 & & 190 \\
\hline A & SE & 0 & & 214 \\
\hline A & SE & 0 & & 218 \\
\hline A & SE & 0 & & 323 \\
\hline A & SE & 1 & 23,1 & 43 \\
\hline A & SE & 1 & 23,1 & $82 B$ \\
\hline A & SE & 1 & 23,1 & 157 \\
\hline A & SE & 1 & 23,1 & 189 \\
\hline A & SE & 1 & 80 & 223 \\
\hline A & SE & 1 & 80 & 224 \\
\hline A & SE & 1 & 80 & 256 \\
\hline A & SE & 1 & 23,1 & 274 \\
\hline A & SE & 1 & 80 & 289 \\
\hline A & SE & 1 & 23,1 & 291 \\
\hline A & SE & 2 & $33 ; 23,1$ & $82 A$ \\
\hline A & SE & 2 & 23,$1 ; 3,3$ & 128 \\
\hline A & SE & 2 & $80 ; 23,1$ & 155 \\
\hline A & SE & 2 & $80 ; 23,1$ & 241 \\
\hline A & SE & 2 & $80 ; 23,1$ & 296 \\
\hline A & SE & 3 & $80 ; 3,3 ; 2,8$ & 131 \\
\hline A & SE & 4 & $80 ; 4,4 ; 3,8 ; 2,8$ & 123 \\
\hline A & SE & 4 & $80 ; 4,4 ; 3,8 ; 2,8$ & 125 \\
\hline A & SE & 4 & 5,$8 ; 4,1 ; 3,0 ; 2,8$ & 183 \\
\hline A & SE & 5 & 23,$1 ; 16,2 ; 3,3 ; 1,6$ & $230 \mathrm{~A}$ \\
\hline A & SE & 5 & 23,$1 ; 16,2 ; 3,3 ; 1,6$ & $230 \mathrm{~B}$ \\
\hline A & SE & 6 & 9,$4 ; 5,5 ; 4,3 ; 3,8 ; 2,8 ; 2,3$ & 94 \\
\hline A & SE & 6 & $80 ; 4,4 ; 3,8 ; 3,3 ; 2,8 ; 1,6$ & 120 \\
\hline A & $\mathrm{CH}$ & 0 & & 543 \\
\hline A & $\mathrm{CH}$ & 0 & & 555 \\
\hline A & $\mathrm{CH}$ & 1 & 23,1 & 563 \\
\hline A & $\mathrm{CH}$ & 1 & 23,1 & 567 \\
\hline A & $\mathrm{CH}$ & 1 & 80 & 576 \\
\hline A & $\mathrm{CH}$ & 2 & $80 ; 23.1$ & 533 \\
\hline A & $\mathrm{CH}$ & 2 & $33 ; 6,5$ & 595 \\
\hline A & $\mathrm{CH}$ & 2 & $33 ; 6,6$ & 596 \\
\hline
\end{tabular}




\section{Continuação}

\section{A. veronii sobria}

\begin{tabular}{|c|c|c|c|c|}
\hline Amostra & Periodo & $\begin{array}{c}\text { No de } \\
\text { plasmidios }\end{array}$ & Peso molecular (kb) & $\begin{array}{c}\mathbf{N}^{\mathbf{O}} \\
\text { da cepa }\end{array}$ \\
\hline A & $\mathrm{CH}$ & 3 & $33 ; 23,1 ; 6,5$ & 560 \\
\hline A & $\mathrm{CH}$ & 3 & $80 ; 33 ; 6,5$ & 578 \\
\hline A & $\mathrm{CH}$ & 3 & $80 ; 33 ; 6,6$ & 580 \\
\hline A & $\mathrm{CH}$ & 3 & $80 ; 33 ; 6.5$ & 592 \\
\hline A & $\mathrm{CH}$ & 4 & $80 ; 33 ; 23,1 ; 6,5$ & 561 \\
\hline A & $\mathrm{CH}$ & 4 & $80 ; 23,1 ; 5,5 ; 3,3$ & 597 \\
\hline A & $\mathrm{CH}$ & 4 & $80 ; 23,1 ; 5,5 ; 3,3$ & 598 \\
\hline A & $\mathrm{CH}$ & 4 & $80 ; 23,1 ; 5,5 ; 3,3$ & 600 \\
\hline A & $\mathrm{CH}$ & 4 & $80 ; 23,1 ; 5,5 ; 3,6$ & 601 \\
\hline A & $\mathrm{CH}$ & 6 & $80 ; 16,2 ; 5,5 ; 3,0 ; 2,8 ; 1,8$ & 582 \\
\hline A & $\mathrm{CH}$ & 5 & $80 ; 5,5 ; 3,0 ; 2,8 ; 1,8$ & 589 \\
\hline A & $\mathrm{CH}$ & 7 & $80 ; 16,2 ; 5,5 ; 4,4 ; 3,0 ; 2,8 ; 1,8$ & 590 \\
\hline $\mathbf{P}$ & SE & 0 & & 30 \\
\hline $\mathbf{P}$ & SE & 0 & & 31 \\
\hline $\mathbf{P}$ & SE & 0 & & 34 \\
\hline $\mathbf{P}$ & SE & 0 & & 42 \\
\hline $\mathbf{P}$ & SE & 0 & & 75 \\
\hline $\mathbf{P}$ & SE & 0 & & 85 \\
\hline$P$ & SE & 0 & & 103 \\
\hline $\mathbf{P}$ & SE & 0 & & 111 \\
\hline $\mathbf{P}$ & SE & 0 & & 117 \\
\hline $\mathbf{P}$ & SE & 0 & & 132 \\
\hline $\mathbf{P}$ & SE & 0 & & 149 \\
\hline $\mathbf{P}$ & SE & 0 & & 166 \\
\hline $\mathbf{P}$ & SE & 1 & 80 & 93 \\
\hline $\mathbf{P}$ & SE & 1 & 23,1 & 115 \\
\hline $\mathbf{P}$ & SE & 1 & 23,1 & 122 \\
\hline $\mathbf{P}$ & SE & 1 & 33 & 128 \\
\hline $\mathbf{P}$ & SE & 1 & 33 & 129 \\
\hline $\mathbf{P}$ & SE & 1 & 33 & 133 \\
\hline $\mathbf{P}$ & SE & 1 & 80 & 134 \\
\hline $\mathbf{P}$ & SE & 1 & 6.5 & 154 \\
\hline $\mathbf{P}$ & SE & 1 & 80 & 172 \\
\hline $\mathbf{P}$ & SE & 1 & 80 & 173 \\
\hline $\mathbf{P}$ & SE & 1 & 80 & 174 \\
\hline$P$ & SE & 1 & 33 & 108 \\
\hline $\mathbf{P}$ & SE & 1 & 33 & 206 \\
\hline $\mathbf{P}$ & SE & 1 & 80 & 214 \\
\hline $\mathbf{P}$ & SE & 1 & 33 & 106 \\
\hline$P$ & SE & 2 & 3,$3 ; 2,0$ & 94 \\
\hline $\mathbf{P}$ & SE & 2 & $23,1: 3,8$ & 112 \\
\hline $\mathbf{P}$ & SE & 2 & $80 ; \mathbf{3 , 8}$ & 118 \\
\hline $\mathbf{P}$ & SE & 2 & 23,$1 ; 3,3$ & 121 \\
\hline $\mathbf{P}$ & SE & 2 & 3,$8 ; 3,3$ & 123 \\
\hline
\end{tabular}




\section{Continuação}

\section{A. veronii sobria}

\begin{tabular}{|c|c|c|c|c|}
\hline Amostra & Periodo & $\begin{array}{c}N^{\circ} \text { de } \\
\text { plasmidios }\end{array}$ & Peso molacular (kb) & $\begin{array}{c}N^{p} \\
\text { da cepa }\end{array}$ \\
\hline $\mathbf{P}$ & SE & 2 & $33 ; 3,8$ & 127 \\
\hline $\mathbf{P}$ & SE & 2 & $33 ; 3,8$ & 131 \\
\hline $\mathbf{P}$ & SE & 2 & $80 ; 23,1$ & 171 \\
\hline $\mathbf{P}$ & SE & 2 & $80 ; 33$ & $126 \mathrm{~A}$ \\
\hline $\mathbf{P}$ & SE & 2 & $80 ; 4,4$ & 179 \\
\hline $\mathbf{P}$ & SE & 2 & $80 ; 4,4$ & 185 \\
\hline $\mathbf{P}$ & SE & 2 & $33 ; 23,1$ & 205 \\
\hline $\mathbf{P}$ & SE & 2 & $33 ; 23,1$ & 221 \\
\hline $\mathbf{P}$ & SE & 3 & 23,$1 ; 4,1 ; 3,8$ & 116 \\
\hline $\mathbf{P}$ & SE & 3 & $80 ; 3,8 ; 3,3$ & 124 \\
\hline $\mathbf{P}$ & SE & 3 & $80 ; 3,8 ; 3,3$ & 125 \\
\hline $\mathbf{P}$ & SE & 3 & $80 ; 9,4 ; 6.5$ & 165 \\
\hline $\mathbf{P}$ & SE & 4 & $33 ; 9,4 ; 6,5 ; 5,8$ & 119 \\
\hline$P$ & SE & 4 & $33 ; 23,1 ; 1,6 ; 1,0$ & 239 \\
\hline $\mathbf{P}$ & SE & 5 & $80 ; 6,5 ; 5,5 ; 5,1 ; 4,4$ & 167 \\
\hline $\mathbf{P}$ & SE & 5 & $80 ; 23,1 ; 6,5 ; 5,1 ; 4,4$ & 212 \\
\hline $\mathbf{P}$ & SE & 5 & $33 ; 23,1 ; 6,5 ; 5,8 ; 4,4$ & 213 \\
\hline $\mathbf{P}$ & SE & 6 & $33 ; 8,0 ; 6,5 ; 5,5 ; 4,4 ; 3,8$ & $126 \mathrm{~B}$ \\
\hline $\mathbf{P}$ & SE & 7 & $80 ; 23,1 ; 3,3 ; 2,8 ; 1,6 ; 1,0$ & 80 \\
\hline $\mathbf{P}$ & SE & 10 & $43 ; 33 ; 23,1 ; 16,2 ; 9,4 ; 6,5 ; 5,8 ; 5,5 ; 3,8 ; 3,3$ & 177 \\
\hline $\mathbf{P}$ & SE & 11 & $43 ; 33 ; 23,1 ; 16,2 ; 9,4 ; 8,0 ; 6,5 ; 5,8 ; 4,4 ; 3,8 ; 3,3$ & 176 \\
\hline $\mathbf{P}$ & SE & 12 & $80 ; 43 ; 33 ; 23,1 ; 9,4 ; 8,0 ; 6,5 ; 5,8 ; 3,3 ; 2,8 ; 2,0 ; 1,3$ & 223 \\
\hline $\mathbf{P}$ & SE & 14 & $\begin{array}{c}53 ; 43 ; 33 ; 23,1 ; 16,2 ; 9,4 ; 8,0 ; 6,5 ; 4,4 ; 3,8 ; 3,3 \\
1,6 ; 1,0\end{array}$ & 231 \\
\hline $\mathbf{P}$ & $\mathrm{CH}$ & 0 & & 306 \\
\hline $\mathbf{P}$ & $\mathrm{CH}$ & 0 & & 348 \\
\hline $\mathbf{P}$ & $\mathrm{CH}$ & 0 & & 532 \\
\hline$P$ & $\mathrm{CH}$ & 0 & & 609 \\
\hline
\end{tabular}

Nota: $A=a ́ g u a ; P=$ peixe; $C H=$ periodo chuvoso; $S E=$ período seco 


\section{Anexo V}

\begin{tabular}{|c|c|c|c|c|}
\hline \multicolumn{5}{|c|}{ Aeromonas bestiarium } \\
\hline Amostra & Periodo & No de plasmídios & Peso molecular (kb) & No da cepa \\
\hline$A$ & $\mathrm{SE}$ & 0 & & 75 \\
\hline A & $\mathrm{SE}$ & 1 & 23,1 & 159 \\
\hline A & SE & 1 & 23,1 & 236 \\
\hline A & SE & 2 & $33 ; 16,2$ & 1 \\
\hline A & SE & 2 & $33 ; 23,1$ & 68 \\
\hline A & SE & 2 & $33 ; 23,1$ & 76 \\
\hline A & SE & 5 & $43 ; 16,2 ; 6,5 ; 4,4 ; 2,3$ & 251 \\
\hline A & $\mathrm{CH}$ & 2 & $33 ; 16,2$ & 524 \\
\hline A & $\mathrm{CH}$ & 2 & 5,$5 ; 3,3$ & 663 \\
\hline A & $\mathrm{CH}$ & 3 & $80 ; 33 ; 6,5$ & 585 \\
\hline A & $\mathrm{CH}$ & 5 & $33 ; 6,5 ; 3,0 ; 2,8$ & 594 \\
\hline A & $\mathrm{CH}$ & 6 & $33 ; 16,2 ; 6,5 ; 3,3 ; 1,6 ; 1,0$ & 610 \\
\hline $\mathbf{P}$ & SE & 2 & $80 ; 43$ & 76 \\
\hline $\mathbf{P}$ & SE & $\overline{3}$ & $80 ; 23,1 ; 9,4$ & $8 \mathrm{~B}$ \\
\hline $\mathbf{P}$ & SE & 3 & $80 ; 33 ; 23,1$ & 208 \\
\hline $\mathbf{P}$ & SE & 4 & $33 ; 5,8 ; 2,8 ; 2,3$ & 197 \\
\hline $\mathbf{P}$ & SE & 6 & $80 ; 33 ; 23,1 ; 5,8 ; 2,8 ; 2,3$ & 198 \\
\hline $\mathbf{P}$ & $\mathrm{CH}$ & 0 & & 469 \\
\hline $\mathbf{P}$ & $\mathrm{CH}$ & $\mathbf{0}$ & & 543 \\
\hline $\mathbf{P}$ & $\mathrm{CH}$ & $\mathbf{0}$ & & 548 \\
\hline $\mathbf{P}$ & $\mathrm{CH}$ & 0 & & 552 \\
\hline $\mathbf{P}$ & $\mathrm{CH}$ & 0 & & 558 \\
\hline $\mathbf{P}$ & $\mathrm{CH}$ & 0 & & 559 \\
\hline $\mathbf{P}$ & $\mathrm{CH}$ & 1 & 33 & 545 \\
\hline $\mathbf{P}$ & $\mathrm{CH}$ & 1 & 23,1 & 553 \\
\hline $\mathbf{P}$ & $\mathrm{CH}$ & 1 & 80 & 586 \\
\hline $\mathbf{P}$ & $\mathrm{CH}$ & 3 & 23,$1 ; 1,6 ; 1,0$ & 551 \\
\hline $\mathbf{P}$ & $\mathrm{CH}$ & 3 & $80 ; 1,6 ; 1,0$ & $581 A$ \\
\hline $\mathbf{P}$ & $\mathrm{CH}$ & 3 & $80 ; 23,1 ; 16,2$ & 589 \\
\hline
\end{tabular}

Nota: $A=a ́ g u a ; P=p e i x e ; C H=p e r i o d o$ chuvoso; $S E=$ periodo seco 


\section{Anexo VI}

\section{Aeromonas schubertii}

\begin{tabular}{|c|c|c|c|c|}
\hline Amostre & Periodo & $N^{\circ}$ de plasmidios & Peso molocular (kb) & $N$ da cepa \\
\hline$A$ & SE & 1 & 80 & 87 \\
\hline A & SE & 5 & $80 ; 3,3 ; 2,0 ; 1,6 ; 1,3$ & 72 \\
\hline A & SE & 5 & $80 ; 33 ; 9,4 ; 2,8 ; 2,3$ & 53 \\
\hline A & $\mathrm{CH}$ & 0 & & 338 \\
\hline A & $\mathrm{CH}$ & 0 & & 339 \\
\hline A & $\mathrm{CH}$ & 0 & & 343 \\
\hline A & $\mathrm{CH}$ & 0 & & 387 \\
\hline A & $\mathrm{CH}$ & 0 & & 388 \\
\hline A & $\mathrm{CH}$ & 0 & & 392 \\
\hline A & $\mathrm{CH}$ & 0 & & 415 \\
\hline A & $\mathrm{CH}$ & 0 & & 434 \\
\hline A & $\mathrm{CH}$ & $\mathbf{0}$ & & 537 \\
\hline A & $\mathrm{CH}$ & 0 & & 605 \\
\hline A & $\mathrm{CH}$ & 0 & & 616 \\
\hline A & $\mathrm{CH}$ & 0 & & 627 \\
\hline A & $\mathrm{CH}$ & 0 & & 645 \\
\hline A & $\mathrm{CH}$ & 0 & & 710 \\
\hline A & $\mathrm{CH}$ & 0 & & 715 \\
\hline A & $\mathrm{CH}$ & 0 & & 731 \\
\hline A & $\mathrm{CH}$ & 1 & 80 & 340 \\
\hline A & $\mathrm{CH}$ & 1 & 16.2 & 351 \\
\hline A & $\mathrm{CH}$ & 1 & 16,2 & 354 \\
\hline A & $\mathrm{CH}$ & 1 & 16,2 & 356 \\
\hline A & $\mathrm{CH}$ & 1 & 23,1 & 394 \\
\hline A & $\mathrm{CH}$ & 1 & 23,1 & 395 \\
\hline A & $\mathrm{CH}$ & 1 & 80 & 438 \\
\hline A & $\mathrm{CH}$ & 1 & 80 & 447 \\
\hline A & $\mathrm{CH}$ & 1 & 80 & 502 \\
\hline A & $\mathrm{CH}$ & 1 & 23,1 & 523 \\
\hline A & $\mathrm{CH}$ & 1 & 23.1 & 562 \\
\hline A & $\mathrm{CH}$ & 1 & 80 & 564 \\
\hline A & $\mathrm{CH}$ & 1 & 80 & 570 \\
\hline A & $\mathrm{CH}$ & 1 & 80 & 622 \\
\hline A & $\mathrm{CH}$ & 1 & 80 & 628 \\
\hline A & $\mathrm{CH}$ & 1 & 80 & 632 \\
\hline A & $\mathrm{CH}$ & 1 & 80 & 667 \\
\hline A & $\mathrm{CH}$ & 1 & 80 & 699 \\
\hline A & $\mathrm{CH}$ & 1 & 80 & 708 \\
\hline A & $\mathrm{CH}$ & 1 & 80 & 709 \\
\hline A & $\mathrm{CH}$ & 1 & 80 & 716 \\
\hline A & $\mathrm{CH}$ & 1 & 80 & 729 \\
\hline A & $\mathrm{CH}$ & 1 & 80 & 733 \\
\hline A & $\mathrm{CH}$ & 2 & $80 ; 23,1$ & 336 \\
\hline A & $\mathrm{CH}$ & 2 & $80 ; 23,2$ & 337 \\
\hline A & $\mathrm{CH}$ & 2 & $80 ; 23,1$ & 393 \\
\hline
\end{tabular}




\section{Continuação}

\section{Aeromonas schubertii}

\begin{tabular}{|c|c|c|c|c|}
\hline Amostra & Período & No de plasmidios & Peso molecular (kb) & No da cepa \\
\hline$A$ & $\mathrm{CH}$ & 2 & $80 ; 23,1$ & 397 \\
\hline A & $\mathrm{CH}$ & 2 & 23,$1 ; 3,8$ & 525 \\
\hline A & $\mathrm{CH}$ & 2 & $80 ; 6.5$ & 698 \\
\hline A & $\mathrm{CH}$ & 3 & 9,$4 ; 4,3 ; 3,3$ & 342 \\
\hline A & $\mathrm{CH}$ & 3 & $80 ; 16,2 ; 3,3$ & 346 \\
\hline A & $\mathrm{CH}$ & 3 & $33 ; 16,2 ; 9,4$ & 349 \\
\hline A & $\mathrm{CH}$ & 3 & $33 ; 16,2 ; 9,4$ & 350 \\
\hline A & $\mathrm{CH}$ & 3 & $33 ; 23,1 ; 6,5$ & 426 \\
\hline A & $\mathrm{CH}$ & 3 & $33 ; 23,1 ; 6,5$ & 427 \\
\hline A & $\mathrm{CH}$ & 3 & $80 ; 4,4 ; 3,3$ & 500 \\
\hline A & $\mathrm{CH}$ & 4 & $80 ; 33 ; 16,2 ; 9,4$ & 348 \\
\hline A & $\mathrm{CH}$ & 4 & $80 ; 3,3 ; 3,0 ; 2,0$ & 379 \\
\hline A & $\mathrm{CH}$ & 4 & $80 ; 6,5 ; 4,4 ; 3,0$ & 458 \\
\hline A & $\mathrm{CH}$ & 5 & $80 ; 43 ; 23,1 ; 9,4 ; 6,5$ & 335 \\
\hline A & $\mathrm{CH}$ & 5 & $43 ; 23,1 ; 9,4 ; 4,3 ; 3,3$ & 344 \\
\hline A & $\mathrm{CH}$ & 5 & $80 ; 9,4 ; 4,4 ; 3,8 ; 3,3$ & 381 \\
\hline A & $\mathrm{CH}$ & 5 & $80 ; 33 ; 6,5 ; 4,4 ; 3,3$ & 441 \\
\hline A & $\mathrm{CH}$ & 6 & $80 ; 23,1 ; 9,4 ; 6,5 ; 4,4 ; 3,3$ & 368 \\
\hline A & $\mathrm{CH}$ & 6 & $80 ; 23,1 ; 9,4 ; 6,5 ; 5,8 ; 5,5 ; 4,4 ; 3,3$ & 371 \\
\hline A & $\mathrm{CH}$ & 6 & 6,$5 ; 4,4 ; 4,1 ; 3,8 ; 3,3 ; 2,8$ & 403 \\
\hline A & $\mathrm{CH}$ & 7 & $80 ; 23,1 ; 9,4 ; 6,5 ; 5,5 ; 4,4 ; 3,3$ & 375 \\
\hline A & $\mathrm{CH}$ & 7 & $80 ; 23,1 ; 9,4 ; 6,5 ; 5,5 ; 4,4 ; 3,3$ & 376 \\
\hline A & $\mathrm{CH}$ & 7 & $80 ; 23,1 ; 9,4 ; 6,5 ; 5,5 ; 4,4 ; 3,3$ & 378 \\
\hline A & $\mathrm{CH}$ & 8 & $80 ; 33 ; 16,2 ; 9,4 ; 6,5 ; 5,5 ; 4,4 ; 3,3$ & 347 \\
\hline A & $\mathrm{CH}$ & 8 & $80 ; 23,1 ; 16,2 ; 9,4 ; 6,5 ; 5,5 ; 4,4 ; 3,3$ & 359 \\
\hline A & $\mathrm{CH}$ & 8 & $80 ; 23,1 ; 16,2 ; 9,4 ; 6,5 ; 5,5 ; 4,4 ; 3,3$ & 361 \\
\hline A & $\mathrm{CH}$ & 8 & $80 ; 23,1 ; 16,2 ; 9,4 ; 6,5 ; 5.5 ; 4,4 ; 3,3$ & 362 \\
\hline A & $\mathrm{CH}$ & 8 & $80 ; 23,1 ; 16,2 ; 9,4 ; 6,5 ; 5,5 ; 4,4 ; 3,3$ & 364 \\
\hline A & $\mathrm{CH}$ & 8 & $80 ; 23,1 ; 16,2 ; 9,4 ; 6.5 ; 5,8 ; 4,4 ; 3,3$ & 367 \\
\hline A & $\mathrm{CH}$ & 8 & $80 ; 23,19,4 ; 6,5 ; 5,8 ; 4,4 ; 3,3 ; 3,0$ & 369 \\
\hline A & $\mathrm{CH}$ & 8 & $80 ; 23,19,4 ; 6,5 ; 5,8 ; 5,5 ; 4,4 ; 3,3$ & $370 A$ \\
\hline $\mathbf{P}$ & SE & 0 & & 225 \\
\hline $\mathbf{P}$ & $\mathrm{CH}$ & 0 & & 249 \\
\hline $\mathbf{P}$ & $\mathrm{CH}$ & 0 & & 279 \\
\hline $\mathbf{P}$ & $\mathrm{CH}$ & 0 & & 456 \\
\hline $\mathbf{P}$ & $\mathrm{CH}$ & 0 & & 459 \\
\hline $\mathbf{P}$ & $\mathrm{CH}$ & 0 & & 460 \\
\hline $\mathbf{P}$ & $\mathrm{CH}$ & $\mathbf{0}$ & & 461 \\
\hline $\mathbf{P}$ & $\mathrm{CH}$ & $\mathbf{0}$ & & 462 \\
\hline $\mathbf{P}$ & $\mathrm{CH}$ & 0 & & 464 \\
\hline $\mathbf{P}$ & $\mathrm{CH}$ & 0 & & 475 \\
\hline $\mathbf{P}$ & $\mathrm{CH}$ & $\mathbf{0}$ & & 476 \\
\hline $\mathbf{P}$ & $\mathrm{CH}$ & 0 & & 485 \\
\hline $\mathbf{P}$ & $\mathrm{CH}$ & 0 & & 487 \\
\hline
\end{tabular}




\section{Continuação}

\begin{tabular}{|c|c|c|c|c|}
\hline \multicolumn{5}{|c|}{ Aeromonas schubertii } \\
\hline Amostra & Periodo & $\mathbf{N}^{\circ}$ de plasmídios & Peso molecular (kb) & $\mathbf{N}^{\circ}$ da cepa \\
\hline $\mathbf{P}$ & $\mathrm{CH}$ & 0 & & 500 \\
\hline $\mathbf{P}$ & $\mathrm{CH}$ & 0 & & 502 \\
\hline $\mathbf{P}$ & $\mathrm{CH}$ & 0 & & 529 \\
\hline $\mathbf{P}$ & $\mathrm{CH}$ & 1 & 33 & 244 \\
\hline $\mathbf{P}$ & $\mathrm{CH}$ & 1 & 80 & 304 \\
\hline $\mathbf{P}$ & $\mathrm{CH}$ & 1 & 80 & 305 \\
\hline $\mathbf{P}$ & $\mathrm{CH}$ & 1 & 80 & 322 \\
\hline $\mathbf{P}$ & $\mathrm{CH}$ & 1 & 80 & 351 \\
\hline $\mathbf{p}$ & $\mathrm{CH}$ & 1 & 80 & 438 \\
\hline $\mathbf{P}$ & $\mathrm{CH}$ & 1 & 80 & 444 \\
\hline $\mathbf{P}$ & $\mathrm{CH}$ & 1 & 80 & 445 \\
\hline $\mathbf{P}$ & $\mathrm{CH}$ & 1 & 80 & 452 \\
\hline $\mathbf{P}$ & $\mathrm{CH}$ & 1 & 80 & 454 \\
\hline $\mathbf{P}$ & $\mathrm{CH}$ & 1 & 16,2 & 316 \\
\hline $\mathbf{P}$ & $\mathrm{CH}$ & 2 & $80 ; 33$ & 253 \\
\hline $\mathbf{P}$ & $\mathrm{CH}$ & 2 & $80 ; 23,1$ & 280 \\
\hline $\mathbf{P}$ & $\mathrm{CH}$ & 2 & $33 ; 23,1$ & 282 \\
\hline $\mathbf{P}$ & $\mathrm{CH}$ & 2 & 80; 33 & $287 A$ \\
\hline$P$ & $\mathrm{CH}$ & 2 & 80,33 & $287 B$ \\
\hline $\mathbf{P}$ & $\mathrm{CH}$ & 3 & $80 ; 6,5 ; 5,5$ & 284 \\
\hline $\mathbf{P}$ & $\mathrm{CH}$ & 4 & $80 ; 33 ; 3,8 ; 2,0$ & 250 \\
\hline $\mathbf{P}$ & $\mathrm{CH}$ & 4 & 23,$1 ; 5,5 ; 4,4 ; 3,3$ & 481 \\
\hline$P$ & $\mathrm{CH}$ & 4 & $80 ; 23,1 ; 5,5 ; 4,3$ & 490 \\
\hline $\mathbf{P}$ & $\mathrm{CH}$ & 4 & $80 ; 23,1 ; 5,5 ; 4,3$ & 492 \\
\hline $\mathbf{P}$ & $\mathrm{CH}$ & 4 & $80 ; 23,1 ; 5,5 ; 4,3$ & 493 \\
\hline $\mathbf{P}$ & $\mathrm{CH}$ & 4 & $80 ; 23,1 ; 5,5 ; 4,3$ & 495 \\
\hline $\mathbf{P}$ & $\mathrm{CH}$ & 4 & $80 ; 23,1 ; 5,5 ; 4,3$ & 498 \\
\hline $\mathbf{P}$ & $\mathrm{CH}$ & 4 & $80 ; 23,1 ; 5,5 ; 4,3$ & 499 \\
\hline $\mathbf{P}$ & $\mathrm{CH}$ & 5 & $80 ; 9,4 ; 4,4 ; 3,3 ; 2,8$ & 248 \\
\hline $\mathbf{P}$ & $\mathrm{CH}$ & 6 & $80 ; 33 ; 23,1 ; 4,4 ; 4,1 ; 3,8$ & 255 \\
\hline $\mathbf{P}$ & $\mathrm{CH}$ & 6 & $80 ; 33 ; 6,5 ; 5,5 ; 3,3 ; 2,3$ & 301 \\
\hline $\mathbf{P}$ & $\mathrm{CH}$ & 7 & $33 ; 23,1 ; 5,8 ; 5,5 ; 4,1 ; 3,8 ; 2,0$ & 269 \\
\hline $\mathbf{P}$ & $\mathrm{CH}$ & 7 & $33 ; 23,1 ; 5,8 ; 5,5 ; 4,1 ; 3,8 ; 2,0$ & 270 \\
\hline $\mathbf{P}$ & $\mathrm{CH}$ & 7 & $80 ; 16,2 ; 4,4 ; 3,8 ; 3,3 ; 2,3 ; 2,0$ & 308 \\
\hline $\mathbf{P}$ & $\mathrm{CH}$ & 8 & $80 ; 33 ; 23,1 ; 5,5 ; 5,1 ; 4,4 ; 4,1 ; 3,8$ & 256 \\
\hline $\mathbf{P}$ & $\mathrm{CH}$ & 8 & $80 ; 43 ; 23,1 ; 9,4 ; 6,5 ; 5,5 ; 4,4 ; 3,8$ & 330 \\
\hline
\end{tabular}

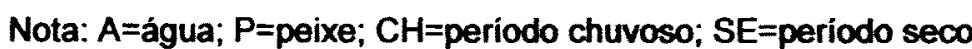




\section{ANEXO VII}

EST.3 Totais diários de precipitação $(\mathrm{mm})$ - 2001

\begin{tabular}{|c|c|c|c|c|c|c|c|c|c|c|c|c|}
\hline DIA / MÊS & JAN. & FEV. & MAR. & ABR. & MAI. & JUN. & JUL. & AGO. & SET. & OUT. & NOV. & DEZ. \\
\hline 1 & 0,4 & 5,5 & 0,1 & 21,0 & 0,0 & 0,1 & 0,1 & 0,0 & 0,0 & 103,6 & 0,0 & 1,3 \\
\hline 2 & 0,0 & 0,1 & 9,9 & 2,0 & 0,0 & 0,0 & 0,1 & 0,0 & 0,0 & 5,1 & 0,0 & 0,0 \\
\hline 3 & 0,0 & 12,5 & 0,2 & 0,0 & 0,0 & 0,0 & 0,0 & 0,0 & 0,0 & 0,0 & 0,0 & 0,0 \\
\hline 4 & 0,7 & 12,6 & 0,0 & 0,0 & 2,8 & 0,0 & 0,1 & 0,0 & 0,1 & 0,0 & 1,0 & 0,0 \\
\hline 5 & 0,1 & 38,0 & 0,5 & 12,0 & 0,0 & 0,0 & 0,0 & 0,1 & 0,0 & 0,0 & 0,0 & 0,2 \\
\hline 6 & 0,0 & 14,1 & 0,1 & 0,0 & 0,0 & 0,0 & 0,0 & 0,0 & 1,6 & 0,0 & 0,0 & 1,1 \\
\hline 7 & 0,0 & 0,3 & 20,7 & 0,0 & 2,3 & 0,0 & 0,0 & 0,0 & 0,1 & 0,0 & 0,1 & 0,0 \\
\hline 8 & 11,0 & 0,0 & 14,5 & 0,0 & 0,5 & 0,0 & 0,0 & 0,0 & 0,0 & 18,3 & 0,0 & 1,6 \\
\hline 9 & 35,3 & 1,1 & 9,3 & 0,4 & 0,1 & 7,0 & 0,0 & 0,0 & 0,0 & 0,1 & 0,0 & 56,4 \\
\hline 10 & 0,0 & 6,3 & 4,4 & 0,0 & 2,5 & 0,0 & 0,1 & 0,0 & 0,0 & 2,5 & 7,0 & 20,3 \\
\hline 11 & 0,0 & 7,6 & 0,1 & 0,0 & 4,3 & 0,0 & 0,0 & 0,0 & 1.9 & 1,3 & 40,9 & 0,6 \\
\hline 12 & 0,0 & 17,8 & 0,1 & 0,2 & 21,7 & 0,0 & 5,1 & 0,0 & 0,1 & 0,2 & 1,0 & 0,0 \\
\hline 13 & 3,4 & 9,3 & 0,0 & 0,0 & 30,9 & 0,1 & 0,0 & 0,1 & 0.0 & 0,0 & 0,1 & 11,1 \\
\hline 14 & 0,1 & 0,6 & 0,1 & 0,0 & 0,5 & 0,1 & 0,0 & 0,1 & 21,0 & 0,1 & 1,7 & 17,5 \\
\hline 15 & 0,0 & 0,2 & 7,4 & 0,0 & 0,0 & 0,0 & 0,0 & 0,1 & 8,0 & 0,1 & 4,4 & 7,6 \\
\hline 16 & 0,0 & 20,2 & 0,1 & 0,0 & 11,7 & 0,0 & 0,0 & 0,1 & 0,0 & 0,0 & 2,0 & 12,1 \\
\hline 17 & 0,0 & 1,4 & 17,5 & 0,1 & 0,2 & 0,0 & 0,0 & 0,0 & 0,1 & 0,0 & 0,3 & 0,0 \\
\hline 18 & 0,2 & 0,7 & 0,2 & 0,2 & 0,0 & 6,5 & 0,0 & 0,0 & 0,5 & 0,4 & 0,0 & 0,2 \\
\hline 19 & 0,1 & 1,8 & 0,0 & 0,0 & 0,5 & 0,4 & 0,0 & 0,0 & 0,1 & 76,8 & 0,0 & 0,0 \\
\hline 20 & 0,0 & 0,0 & 21,6 & 0,0 & 0,0 & 0,0 & 0,0 & 0,0 & 0,7 & 18,3 & 0,0 & 1,8 \\
\hline 21 & 0,0 & 0,0 & 4,6 & 0,0 & 0,0 & 0,0 & 0,0 & 6,1 & 0,1 & 5,6 & 0,0 & 0,7 \\
\hline 22 & 0,0 & 0,0 & 2,7 & 1,9 & 0,3 & 0,0 & 1,1 & 5,0 & 5,5 & 11,8 & 6,3 & 5,8 \\
\hline 23 & 2,9 & 0,1 & 0,8 & 0,1 & 0,0 & 0,0 & 0,4 & 3,2 & 0,8 & 0,0 & 0,1 & 15,2 \\
\hline 24 & 25,3 & 2,9 & 43,2 & 6,0 & 0,0 & 0,0 & 2,0 & 4,5 & 0,0 & 0,0 & 0,1 & 1,5 \\
\hline 25 & 7,6 & 1,9 & 0,2 & 0,0 & 0,0 & 0,0 & 1,0 & 0,1 & 13,6 & 0,0 & 0,0 & 0,0 \\
\hline 26 & 0,1 & 0,1 & 5,5 & 0,0 & 0,0 & 12,2 & 28,2 & 0,0 & 0,1 & 0,0 & 0,0 & 0,2 \\
\hline 27 & 34,8 & 0,1 & 1,0 & 0,0 & 12,3 & 0,0 & 11,6 & 0,0 & 0,2 & 0,1 & 7,5 & 0,0 \\
\hline 28 & 15,4 & 0,0 & 32,9 & 0,0 & 0,0 & 0,0 & 10,9 & 0,5 & 0,2 & 0,1 & 34,0 & 3,7 \\
\hline 29 & 0,3 & & 0,6 & 0,0 & 0,0 & 0,0 & 0,1 & 2,2 & 0,3 & 0,0 & 1,9 & 11,1 \\
\hline 30 & 0,3 & & 0,0 & 0,0 & 0,0 & 0,0 & 0,1 & 0,6 & 0,1 & 0,0 & 8,3 & 1,0 \\
\hline 31 & 0,6 & & 0,0 & & 0,0 & & 0,0 & 0,0 & & 0,0 & & 0,0 \\
\hline $\begin{array}{c}\text { total mensal de } \\
\text { precipitação }(\mathrm{mm}) \text { : }\end{array}$ & 138,6 & 155,2 & 198,3 & 43,9 & 90,6 & 26,4 & 60,9 & 22,7 & 55,1 & 244,4 & 116,7 & 171,0 \\
\hline média 1933-2002 & & & & & & & & & & & & \\
\hline ("valor normal"): & 219,8 & 207,0 & 165,0 & 79,6 & 64,1 & 50,7 & 40,0 & 39,1 & 77,1 & 125,5 & 123,3 & 181,3 \\
\hline máximo total diário: & 35,3 & 38,0 & 43,2 & 21,0 & 30,9 & 12,2 & 28,2 & 6,1 & 21,0 & 103,6 & 40,9 & 56,4 \\
\hline
\end{tabular}

Fonte: Instituto Astronômico da Universidade de São Paulo

Nota: a região hachurada corresponde aos dias de coleta realizados 
EST.3

Totais diários de precipitação (mm) - 2002

\begin{tabular}{|c|c|c|c|c|c|c|c|c|c|c|c|c|}
\hline DIA / MÊS & JAN. & FEV. & MAR. & ABR. & MAI. & JUN. & JUL. & AGO. & SET. & OUT. & NOV. & DEZ. \\
\hline 1 & 0,8 & 0,6 & 0,1 & 0,0 & 0,4 & 0,0 & 0,0 & 15,4 & 0,1 & 7,3 & 1,8 & 1,4 \\
\hline 2 & 0,3 & 7,4 & 2,8 & 0,0 & 8,0 & 0,0 & 0,0 & 2,6 & 0,0 & 0,0 & 0,0 & 1,5 \\
\hline 3 & 0,0 & 2,4 & 0,2 & 9,0 & 0,8 & 0,1 & 0,0 & 6,1 & 0,1 & 0,0 & 0,0 & 0,0 \\
\hline 4 & 0,0 & 0,0 & 16,0 & 0,0 & 0,0 & 0,2 & 0,0 & 0,0 & 0,1 & 3,0 & 2,0 & 0,2 \\
\hline 5 & 0,0 & 0,0 & 0,1 & 0,0 & 0,1 & 0,0 & 0,0 & 0,1 & 0,0 & 0,0 & 16,4 & 4,6 \\
\hline 6 & 10,0 & 1,7 & 0,0 & 14,8 & 11,0 & 0,0 & 0,1 & 1,4 & 0,0 & 0,0 & 3,2 & 0,4 \\
\hline 7 & 1,1 & 14,6 & 0,0 & 18,1 & 0,2 & 0,0 & 3,1 & 0,0 & 11,6 & 0,0 & 0,0 & 12,4 \\
\hline 8 & 28,2 & 25,3 & 12,5 & 0,0 & 0,0 & 0,0 & 0,0 & 19,3 & 0,0 & 0,0 & 0,2 & 22,5 \\
\hline 9 & 26,5 & 6,8 & 0,1 & 0,0 & 0,1 & 0,0 & 0,0 & 0,0 & 0,0 & 11,4 & 0,0 & 2,4 \\
\hline 10 & 0,0 & 0,0 & 0,1 & 0,0 & 0,0 & 0,0 & 0,0 & 0,0 & 0,0 & 0,0 & 15,6 & 0,0 \\
\hline 11 & 7,3 & 9,8 & 0,0 & 0,0 & 0,0 & 0,0 & 8,0 & 0,0 & 0,0 & 0,0 & 0,2 & 1,0 \\
\hline 12 & 19,7 & 1,6 & 0,3 & 0,0 & 0,2 & 0,0 & 24,7 & 0,0 & 0,0 & 0,0 & 43,6 & 4,7 \\
\hline 13 & 53,2 & 33,4 & 1,4 & 0,7 & 0,2 & 0,0 & 0,0 & 0,0 & 1,4 & 0,0 & 11,0 & 1,1 \\
\hline 14 & 24,9 & 0,0 & 6,9 & 0,0 & 0,2 & 0,1 & 0,0 & 0,3 & 2,5 & 0,0 & 0,0 & 10,8 \\
\hline 15 & 16,2 & 11,1 & 0,0 & 0,0 & 0,1 & 1,5 & 0,2 & 0,0 & 0,1 & 0,0 & 0,1 & 16,5 \\
\hline 16 & 4,7 & 2,3 & 0,0 & 0,0 & 0,3 & 1,0 & 0,0 & 0,0 & 0,0 & 0,0 & 12,6 & 3,3 \\
\hline 17 & 0,2 & 0,2 & 0,1 & 0,0 & 0,0 & 0,0 & 0,1 & 0,0 & 0,0 & 1,4 & 12,3 & 24,0 \\
\hline 18 & 0,0 & 0,0 & 13,2 & 0,0 & 4,4 & 0,1 & 1,2 & 0,0 & 0,0 & 2,7 & 4,2 & 0,1 \\
\hline 19 & 19,4 & 0,0 & 0,8 & 0,0 & 12,7 & 0,0 & 0,1 & 0,0 & 0,0 & 37,0 & 0,1 & 0,0 \\
\hline 20 & 3,7 & 1,3 & 5,2 & 0,1 & 0,0 & 0,0 & 0,0 & 0,0 & 44,8 & 0,0 & 0,0 & 21,1 \\
\hline 21 & 0,0 & 11,6 & 26,1 & 0,0 & 23,3 & 0,0 & 0,0 & 0,0 & 4,6 & 10,5 & 2,9 & 3,6 \\
\hline 22 & 0,2 & 13,9 & 0.0 & 0,1 & 5,3 & 0,4 & 0,2 & 0,0 & 0,1 & 1,5 & 5,7 & 0,0 \\
\hline 23 & 30,5 & 16,7 & 0,0 & 0,1 & 1,0 & 1,9 & 0,0 & 0,0 & 0,0 & 0,2 & 0,7 & 0,0 \\
\hline 24 & 1,9 & 2,9 & 57,3 & 0,1 & 1,5 & 0,0 & 0,1 & 0,0 & 1,4 & 0,0 & 11,5 & 2,6 \\
\hline 25 & 29,7 & 0,1 & 14,6 & 0,1 & 0,2 & 0,3 & 0,1 & 0,0 & 0,0 & 0,3 & 4,2 & 2,1 \\
\hline 26 & 5,6 & 0,0 & 0,0 & 0,1 & 0,1 & 0,0 & 0,0 & 0,0 & 0,0 & 2,8 & 9,5 & 0,0 \\
\hline 27 & 0,0 & 0,6 & 3,9 & 3,6 & 0,1 & 0,0 & 0,0 & 0,0 & 0,0 & 0,0 & 0,0 & 0,0 \\
\hline 28 & 52,6 & 7,7 & 0,1 & 0,1 & 0,0 & 0,0 & 0,0 & 0,0 & 0,0 & 0,0 & 46,4 & 0,0 \\
\hline 29 & 0,7 & 0,0 & 0,0 & 0,0 & 0,1 & 0,0 & 0,0 & 2,6 & 0,0 & 16,2 & 11,1 & 0,0 \\
\hline 30 & 0,0 & & 0,0 & 1,6 & 0,1 & 0,0 & 0,0 & 0,7 & 0,0 & 31,0 & 2,5 & 0,0 \\
\hline 31 & 12,3 & & 0,0 & & 0,0 & & 2,2 & 9,4 & & 0,5 & & 0,0 \\
\hline $\begin{array}{c}\text { total mensal de } \\
\text { precipitação }(\mathrm{mm}) \text { : }\end{array}$ & 349,7 & 172,0 & 161,8 & 48,5 & 70,4 & 5,6 & 40,1 & 57,9 & 66,8 & 125,8 & 217,8 & 136,3 \\
\hline média 1933-2002 & & & & & & & & & & & & \\
\hline ("valor normal"): & 219,8 & 207,0 & 165,0 & 79,6 & 64,1 & 50,7 & 40,0 & 39,1 & 77,1 & 125,5 & 123,3 & 181,3 \\
\hline máximo total diário: & 53,2 & 33,4 & 57,3 & 18,1 & 23,3 & 1,9 & 24,7 & 19,3 & 44,8 & 37,0 & 46,4 & 24,0 \\
\hline
\end{tabular}

Fonte: Instituto Astronômico da Universidade de São Paulo

Nota: a região hachurada corresponde aos dias de coleta realizados 


\section{ANEXO VIII}

Meios de cultura, soluçōes e reagentes utilizados

Solução de Salina $\mathbf{0 , 8 5 \%}$

- $8,5 \mathrm{~g}$ - Cloreto de Sódio

- $1000 \mathrm{~mL}$ - Água destilada

- Autoclavar a $121^{\circ} \mathrm{C}$ por 15 minutos

Água Peptonada Alcalina 1\% (APA 1\%)

- $1 \mathrm{~g}$ - Peptona Bacteriológica

- 19 -Cloreto de Sódio

- $100 \mathrm{~mL}$ - Água destilada

- $\mathrm{pH}=8,6 \mathrm{com} \mathrm{NaOH} 1 \mathrm{~N}$

- Autoclavar a $121^{\circ} \mathrm{C}$ por 15 minutos

\section{Caldo Lúria}

- $1 \mathrm{~g}$-Triptona

- $0,4 \mathrm{~g}$ - Extrato de Levedura

- $1 \mathrm{~g}$-Cloreto de Sódio

- $\mathrm{pH}=6,8$

- Autoclavar a $121^{\circ} \mathrm{C}$ por 15 minutos 


\section{Caldo Lauril Sulfato Triptose (Merck)}

- $\quad 35,5 \mathrm{~g}$ - Caldo Lauril Sulfato Triptose

- $1000 \mathrm{~L}$ - Água Destilada

- Autoclavar a $121^{\circ} \mathrm{C}$ por 15 minutos

\section{Caldo Escherichia coli (Merck)}

- $37 \mathrm{~g}$ - Caldo E. coli

- $1000 \mathrm{~L}$ - Água Destilada

- Autoclavar a $121^{\circ} \mathrm{C}$ por 15 minutos

\section{Caldo Lactosado (Merck)}

- $100 \mathrm{~mL}$ - Água Destilaa

- 1,3 g-Caldo Lactosado

- Autoclavar a $121^{\circ} \mathrm{C}$ por 15 minutos

\section{Caldo Selenito Cistina (Merck)}

- $80 \mathrm{~mL}$ - Água Destilada

- 1,84 g-Selenito Cistina

- Ferver por 10 minutos

Caldo Rappaport-Vassiliadis (Merck)

- $80 \mathrm{~mL}$ - Água Destilada

- 3,4 g - Rappaport-Vassiliadis

- Autoclavar a $121^{\circ} \mathrm{C}$ por 15 minutos 
Eosina Azul de Metileno (Difco)

- $1000 \mathrm{~mL}$ - Água Destilada

- $36 \mathrm{~g}$ - Eosina Azul de Metileno

- Autoclavar a $121^{\circ} \mathrm{C}$ por 15 minutos

\section{Salmonella-Shigella (Difco)}

- $320 \mathrm{~mL}$ - Água Destilada

- 19,2 g-Salmonella-Shigella

- Autoclavar a $121^{\circ} \mathrm{C}$ por 15 minutos

\section{Ágar Xilose Lisina Desoxicolato (Merck)}

- $320 \mathrm{~mL}$ - Água Destilada

- $17,6 \mathrm{~g}$ - Xilose Lisina Desoxicolato

- Autoclavar a $121^{\circ} \mathrm{C}$ por 15 minutos

\section{Ágar Sulfito de Bismuto (Difco)}

- $320 \mathrm{~mL}$ - Água Destilada

- $16,64 \mathrm{~g}$ - Sulfito de Bismuto

- Não autoclavar

\section{Ágar Amido Ampicilina}

- - 5g - Triptona

- - $5 \mathrm{~g}$ - Peptona Bacteriológica 
- $-5 \mathrm{~g}-$ Cloreto de Sódio $(\mathrm{NaCl})$

- $-10 \mathrm{~g}-$ Amido

- - 15g-Ágar Bacteriológico

- $-1,75 \mathrm{~mL}-$ Vermelho de fenol $0,2 \%$

- $-1000 \mathrm{~mL}-$ Água destilada

- Autoclavar a $121^{\circ} \mathrm{C}$ por 15 minutos

- Resfriar até $60^{\circ} \mathrm{C}$.

- Em fluxo laminar, acrescentar $10 \mu \mathrm{L}$ de ampicilina $500 \mathrm{mg} / \mathrm{mL}$ para cada $100 \mathrm{~mL}$ de meio.

\section{Ágar Sangue Ampicilina}

- $13,6 \mathrm{~g}$ de Müller Hinton (base)

- $1000 \mathrm{~mL}$ - Água Destilada

- Autoclavar a $121^{\circ} \mathrm{C}$ por 15 minutos

- Resfriar até $60^{\circ} \mathrm{C}$.

- Em fluxo laminar, acrescentar 3 a $7 \%$ de sangue de carneiro

\section{Müller Hinton (Merck)}

- $400 \mathrm{~mL}$ - Água Destilada

- 13,6 g-Müller Hinton (Base)

- Autoclavar a $121^{\circ} \mathrm{C}$ por 15 minutos 


\section{Agar Ferro Kligler (DIFCO)}

- 54 gramas - Ágar Ferro Kligler

- $1000 \mathrm{~mL}$ - Água Destilada

- Autoclavar a $121^{\circ} \mathrm{C}$ por 15 minutos

Meio IAL (Instituto Adolfo Lutz) ou Rugai com Lisina

- Foi utilizado tubos de IAL fabricado pelo Instituto Adolfo Lutz

\section{Teste da Citocromo-Oxidase}

Em um tubo tipo "eppendorf", colocar uma pequena porção $(0,001 \mathrm{~g})$ do reativo para oxidase (dicloridrato de tetrametil $p$-fenilenodiamina) e $1 \mathrm{~mL}$ de água destilada. Homogeneizar bem e verter sobre um papel de filtro redondo, ajustado ao tamanho da placa de Petri. Esperar secar antes de usar.

\section{Reativo de Ehrlich para Indol}

- $1 \mathrm{~g}$ - p. dimetilaminobenzaldeído

- $20 \mathrm{~g}$-Ácido Ortofosfórico

- $50 \mathrm{~g}$-Álcool Etílico

- $100 \mathrm{~mL}$ - Água Destilada 


\section{ANEXO IX}

Meios e soluções utilizados

Agarose 1,2\%

- $1,8 \mathrm{~g}$ - Agarose

- $150 \mathrm{~mL}$ - TAE 1x (Tampão Tris- Acetato- EDTA)

Agarose 1,8\%

- 2,7 g-Agarose

- $150 \mathrm{~mL}$ - TAE 1x ( Tampão Tris- Acetato- EDTA)

\section{Solução $50 \times$ (estoque)}

- $242 \mathrm{~g}$ - Tris - base

- $57,1 \mathrm{~mL}$ - Ácido Acético Glacial

- $100 \mathrm{~mL}-$ EDTA- $\mathrm{Na}_{2} \mathrm{pH}=\mathbf{8 , 0}$

- $1000 \mathrm{~mL}$ - Água Destilada q.s.p

\section{Solução de uso $1 \mathrm{X}$}

- $20 \mathrm{~mL}$ - TAE 50X

- $1000 \mathrm{~mL}$ - Água Destilada q.s.p 


\section{Tampão corante $6 X$}

- $0,25 \%$ - Azul de Bromofenol

- $30 \%$ - Glicerina

\section{Tampão Tris-EDTA}

- $10 \mathrm{mM}-$ Tris- $\mathrm{HCl} \mathrm{pH}=8,0$

- $0,1 \mathrm{mM}-\mathrm{EDTA} \mathrm{pH}=8,0$

\section{Solução I}

- $4 \mathrm{mg} / \mathrm{L}$ - Lisozima

- $2 \%-$ Glicose

- $10 \mathrm{nM}-$ EDTA

- $25 \mathrm{nM}-$ Tris- $\mathrm{HCl}(\mathrm{pH}=8,0)$

\section{Solução II}

- $0,2 \mathrm{~N}-\mathrm{NaOH}$

- $1,0 \%$ - SDS

\section{Solução III}

- Solução de Acetato de sódio 3 Molar $(\mathrm{pH}=4,8)$

- Acertar o pH com ácido glacial 


\section{Soluçăo IV}

- $100 \mathrm{nM}$ - Acetato de sódio

- $50 \mathrm{nM}-\mathrm{Tris}-\mathrm{HCl}(\mathrm{pH}=8,0)$

SDS $10 \%$

Solução a $10 \%$ em água destilada $\mathrm{pH}=7,2$

Corante Vistra Green (Amersham Pharmacia Biotech)

- Uso sem diluição - 0,5 $\mu \mathrm{L}$ em $150 \mathrm{~mL}$ de agarose

Solução Brometo de etidio $1 \%$

- $1 \mathrm{~g} \mathrm{EtBr}$

- $100 \mathrm{~mL}$ - Água Destilada 